\title{
40. SEDIMENTARY FACIES AND ASSOCIATED DEPOSITIONAL ELEMENTS OF THE AMAZON FAN ${ }^{1}$
}

\author{
William R. Normark, ${ }^{2}$ John E. Damuth, ${ }^{3}$ and the Leg 155 Sedimentology Group ${ }^{4}$
}

\begin{abstract}
Fifteen sedimentary facies are recognized in the $4 \mathrm{~km}$ of sediment cored at the $17 \mathrm{Leg} 155$ drill sites on the Amazon Fan. The Amazon Channel, the most recently active channel-levee system, was the primary focus of drilling (10 of the 17 sites) and provides the basis for the association of specific facies with levee, channel, and lobe elements of the fan. Twelve of the facies are terrigenous sediments and comprise the majority of the sections recovered from the four major submarine fan elements: (1) levee/overbank deposits; (2) channel-fill deposits (high amplitude reflection [HAR] units); (3) depositional lobe and crevasse splay deposits (high amplitude reflection packet [HARP] units); and (d) mass-transport deposits (MTDs). Levee systems and their overbank deposits are composed predominantly of six mud and silt facies that are differentiated by internal structure (e.g., cross-stratification), bed thickness, grain-size variations within silt beds, interbedded silt and mud, and clayey sediment. A seventh facies composed of organized sand beds is less common in levee deposits. In contrast, this organized sand facies, plus two other, more prevalent sand and gravel facies, form thick-bedded sand and gravel units in channel-fill deposits (HAR units), laterally extensive deposits at the bases of levee systems (HARP units), and lobe deposits on the lower fan. When the fan is active during glacial lowstands, the channel-levee systems (e.g., Amazon Channel) rapidly advance downfan as much as $20 \mathrm{~m} / \mathrm{yr}$ prograding over coeval lobe deposits formed at the mouth of the advancing channel-levee system. This progradation rate is about three orders of magnitude greater than the average sediment aggradation rate on levee crests, as shown by stratigraphic correlation studies presented elsewhere in this volume. Consequently, even levees of relatively low relief on the lower fan are effective in confining sandy turbidity and related gravity-controlled flows within the active channel until the lobe area beyond the channel mouth is reached.

Three distinctive muddy facies (including deformed mud with contorted or folded beds, sheared zones, and mud clasts; disorganized mud with scattered pebbles and granules; and homogeneous, structureless mud) characterize thick, volumetrically important, MTDs of regional extent throughout the fan. Three additional facies, biogenic mud, biogenic sand, and chemogenic sediment, are rare and volumetrically compose only $\sim 1 \%$ of the total core recovered. The biogenic mud commonly forms very thin pelagic or hemipelagic drapes on older, abandoned, or inactive levee systems of the fan, and is deposited across the entire fan during interglacial highstands of sea level, such as the present Holocene, when the fan is temporarily inactive.
\end{abstract}

\section{INTRODUCTION}

One of the objectives for drilling on the Amazon Fan during Leg 155 was to improve our understanding of the growth processes of large turbidite systems. In addition, facies distinctions, together with rates of deposition for the major turbidite elements (e.g., levees, channels, lobes) of the Amazon Fan can provide insights into depositional processes that, in turn, can be used to interpret processes on other modern fans. Even though the Amazon Fan is a deep-water, passive-margin deposit, to the extent that the facies for the Amazon Fan might prove comparable to those from ancient turbidite deposits, the results of the drilling program can help evaluate existing depositional models based on outcrop mapping. Knowledge of the sedimentary facies and composition for ancient turbidite deposits, whether studied through outcrop mapping or with borehole data, provides only limited scope for sedimentary-process modeling and interpretation because of the lack of knowledge of the original shape (especially the vertical relief) of the depositional surface as a result of compaction and, in some cases, tectonism (Normark et al., 1993). On the other hand, studies of modern turbidite systems, such as the Amazon

${ }^{1}$ Flood, R.D., Piper, D.J.W., Klaus, A., and Peterson, L.C. (Eds.), 1997. Proc. ODP, Sci. Results, 155: College Station, TX (Ocean Drilling Program).

${ }^{2}$ U.S. Geological Survey, 345 Middlefield Road, Menlo Park, CA 94025, U.S.A. wnormark@mojave.wr.usgs.gov

${ }^{3}$ Department of Geology and Earth Resource and Environment Center, The University of Texas at Arlington, Arlington, TX 76019, U.S.A.

${ }^{4}$ A. Cramp, R.D. Flood, R.N. Hiscott, R.O. Kowsmann, M. Lopez, P.L. Manley, F. Nanayama, D.J.W. Piper, C. Pirmez, and R. Schneider.
Fan, provide good knowledge of the deposit morphology, especially where side-scan sonar and swath bathymetric data are available. The internal structure can be determined with seismic-reflection profiling systems, but without sediment samples, only interpretive acoustic or seismic facies are defined (e.g., Damuth et al., 1988; Manley and Flood, 1988; Flood et al., 1991). With few exceptions, sedimentary facies based on core samples are limited to the upper $10 \mathrm{~m}$ for most modern turbidite systems (Normark et al., 1993). The only previous deep drilling that focused on a modern turbidite system was Deep Sea Drilling Program (DSDP) Leg 96 on the Mississippi Fan (Bouma et al., 1986). This drilling program, however, was primarily directed toward coring key seismic-stratigraphic boundaries, and continuous coring was generally limited to only the upper $100 \mathrm{~m}$.

Attempts to establish depositional process models for submarine turbidite systems by comparing sedimentary facies from outcrops and boreholes from ancient deposits with morphologic features from modern deposits is complicated by physical and temporal scale issues (Mutti and Normark, 1987, 1991). It is necessary to compare features from modern and ancient deposits that are of the same general physical size, and the various techniques used to map the deposits need to provide about the same resolution of detail. In an attempt to improve our understanding of submarine fan growth models, Mutti and Normark $(1987,1991)$ argued that comparisons of fan morphology, acoustic facies, and outcrop data, which encompass entire deposits, commonly result in misleading interpretations of depositional processes. They suggested that comparisons be limited to specific architectural elements of comparable physical and temporal scales. These include basic elements that are commonly recognized in most turbid- 
ite systems such as channels, channel deposits, overbank (levee in modern systems) deposits, lobe deposits, and special features in the channel-lobe transition zone. By comparing various modern and ancient examples of these elements, they identified common depositional features and commented on the related depositional processes (Mutti and Normark, 1987, 1991).

Leg 155 drilling on the Amazon Fan provides the first opportunity to compare sedimentologic facies with good morphologic and seismic-stratigraphic frameworks to define the growth pattern of a major turbidite system (Flood, Piper, Klaus, et al., 1995). This can provide a guide to developing depositional models using observations for other modern and ancient turbidite systems that are characterized by prominent channel-levee systems. Similar to other large, passive margin fans, the Amazon Fan has an extensive distributary pattern of large channel-levee systems (Barnes and Normark, 1985), and the complex pattern of these meandering systems has now been wellmapped using SeaBeam swath bathymetric and long-range, side-scan sonar (GLORIA) data (Damuth et al., 1988; Flood et al., 1991). Seismic-stratigraphic analysis of seismic-reflection data revealed the distribution of buried channel-levee systems and their sequence of development. Only one system tends to be active at any given time. Breaching the levee of the active channel produces an avulsion event that leads to the development of a new distributary channel and abandonment of the previously active channel below the point of avulsion. The fan thus grows through progradation, lateral migration, and stacking of these channel-levee systems, which individually are commonly up to $50 \mathrm{~km}$ wide and exceed $100 \mathrm{~km}$ in length (Damuth et al., 1983, 1988; Manley and Flood, 1988; Pirmez and Flood, 1995).

Leg 155 recovered $4 \mathrm{~km}$ of core during continuous coring at 17 sites (Fig. 1), which, for the first time, provided the sedimentary compositions with bed-by-bed description and facies for several major stages of development of a modern turbidite system. The core recovered was dominantly fine-grained sediment from the channel-levee systems. Interpretation of wireline logs in combination with Formation MicroScanner (FMS) images allowed Pirmez et al., (this volume) to construct bed-by-bed descriptions of more than $400 \mathrm{~m}$ of coarse-grained intervals where core recovery was generally less than $25 \%$. These detailed descriptions of the third (vertical) dimension of a submarine fan provide "ground-truth" information for the previous interpretations of facies and depositional processes based on seismic, side-scan sonar, and bathymetric data. Drilling also provided much needed chronostratigraphic control on the seismic-stratigraphic interpretation of the sequence of development of the channel-levee systems and related elements of the fan (Shipboard Scientific Party, 1995d; Piper et. al., Chapter 39, this volume; Maslin and Mikkelsen, this volume; Showers et al., this volume). The resulting control on the age of sediment, together with the morphology and internal structure, allows for a much better understanding of the depositional processes of the fan (e.g., Hiscott et al.; Pirmez et al.; Piper and Deptuck, all inthis volume), as well as a chronological history of the growth pattern.

The purpose of the following synthesis is to describe the sedimentary facies recovered from Leg 155 sites based solely on the sediment core recovered. We have purposely avoided or minimized the use of petrophysical (wireline logs) or seismic-reflection data in our classifications and descriptions, because we wanted these descriptions to reflect sedimentary facies as observed in outcrop or other sediment cores. We have evaluated the contribution of these sediment facies based on our understanding of fan growth. It is beyond the scope of this synthesis to make detailed comparisons of these sedimentary facies with those of other turbidite systems, modern or ancient, or to evaluate modern and/or ancient fan models (e.g., Mutti and Ricci Lucchi, 1972; Mutti, 1979; Mutti and Normark, 1987, 1991). In addition, we do not try to evaluate the implications of the sedimentary facies of the Amazon Fan for currently popular sequence-stratigraphic models such as the Vail/Exxon conceptual sea-level model (e.g., Vail et al., 1991; Normark et al., 1993).

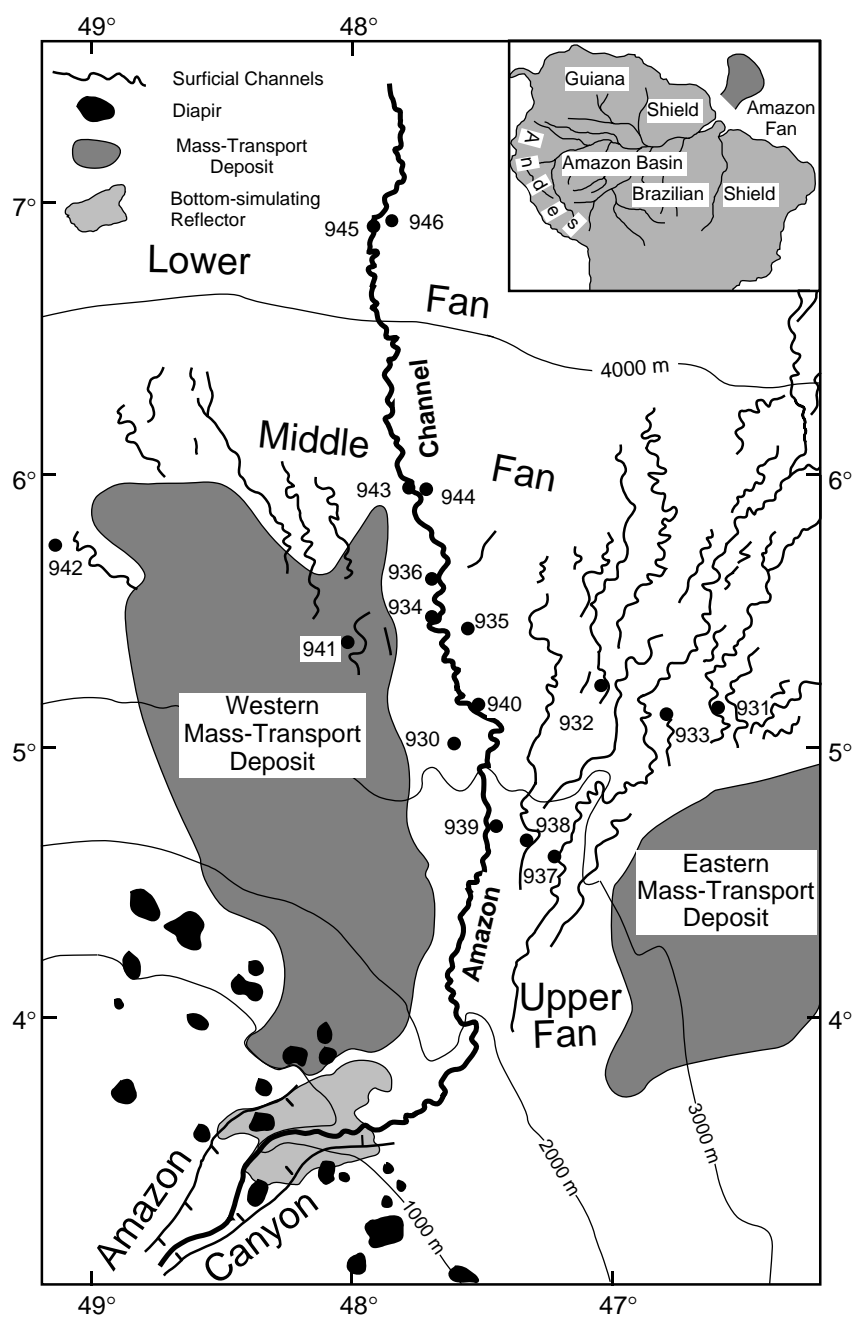

Figure 1. Location of Leg 155 sites in relation to surficial channel systems and MTDs. The Amazon Channel (bold line) is the most recently active channel on the fan. Modified from Flood et al., 1995, and modified from Damuth et al., 1988, and Manley and Flood, 1988.

\section{SEDIMENTARY FACIES}

\section{General}

The facies presented below are based entirely on a megascopic description of the properties of the sediment recovered. Our classification is based on modification of the classification scheme for deepwater facies proposed by Pickering et al. (1986) and was developed through our observations of the Leg 155 cores. Disruption of primary sedimentary structures during coring, the effects of methane gas expansion common in the upper sections at all sites, and incomplete recovery in some coarser grained intervals (Shipboard Scientific Party, 1995c), has probably resulted in our lumping of some distinct facies types that might be recognized by others (e.g., Pickering et al., 1986) as a single facies. A few of the facies - clayey, muddy, and siltyare ubiquitous throughout the 17 sites (Fig. 1). Other facies (e.g., biogenic sand and chemogenic sediment) are extremely rare, and each represents less than $0.001 \%$ of the $4 \mathrm{~km}$ of core recovered.

In the discussions of the distribution of facies and their relation to architectural elements, we comment briefly on the relationship between the sedimentary facies described below and other types of facies distinctions that have been developed for the Amazon Fan. These 


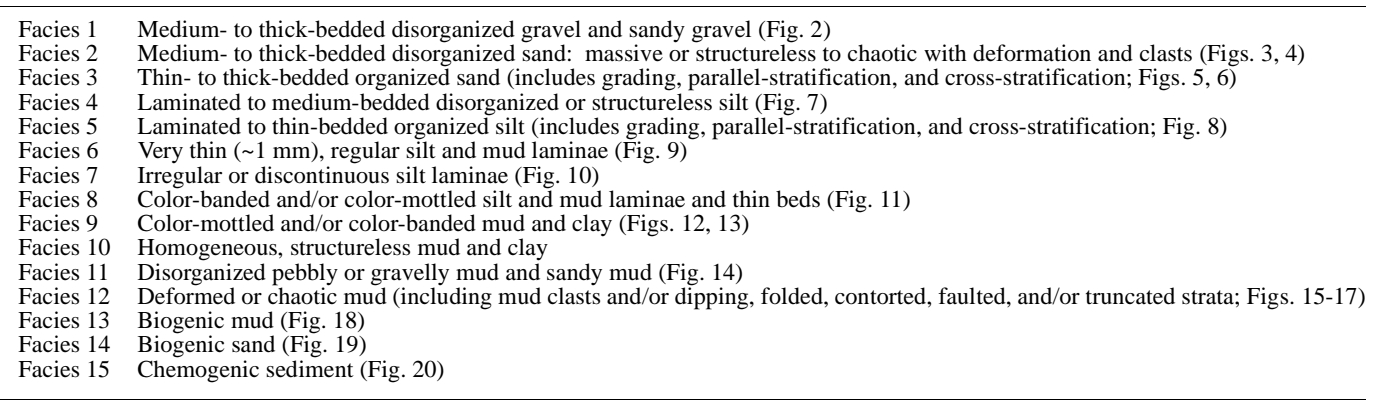

specialized classifications include facies interpretations based on FMS and a suite of other wireline logs (Pirmez et al., this volume), and the detailed (lamina-scale) facies distinctions for fine-grained turbidites (Piper and Deptuck, this volume); both of these studies augment our classification and descriptions of facies presented below, which is based on a bed-by-bed megascopic description of the split-core surfaces. The interpretation of the wireline log and FMS data (Pirmez et al., this volume) includes definition of six facies based on wireline log signatures that correspond to the first nine facies in our classification below. In general, the wireline log facies provide additional characterizations within the coarser grained sections where core recovery was poor to absent; however, they tend to lump facies distinctions in the finer grained sections. In contrast, Piper and Deptuck (this volume) distinguish 12 facies or facies subtypes within the fine-grained (silt, mud, and clay) sediment, thus expanding the facies characters described in this report. Taken together, these facies studies can be used to provide ground truth for the acoustic (or seismic) facies based on seismic-reflection profiling data (e.g., Damuth et al., 1988; Manley and Flood, 1988; Flood et al., 1991).

\section{Description of Facies}

Fifteen major sedimentary facies are recognized in Leg 155 cores from the Amazon Fan (Table 1). These facies are briefly described below, and illustrated examples are provided in Figures 2-20. The facies follow the shipboard distinctions for bed thickness wherein "thick bedded" refers to thicker than $30 \mathrm{~cm}$, "medium bedded" to units 10 to $30 \mathrm{~cm}$ thick, and "thin bedded" to those less than $10 \mathrm{~cm}$ thick (usage simplified from Ingram, 1954; see Shipboard Scientific Party, 1995c). For more detailed descriptions of sediment lithologies for specific holes, the reader should consult the individual site chapters in Flood, Piper, Klaus, et al. (1995) and Plates 1 and 2 (backpocket foldouts; Shipboard Scientific Party, 1995a, 1995b).

\section{Facies 1: Medium- to Thick-Bedded Disorganized Gravel and Sandy Gravel}

The only core recovery of this facies was from apparent high-amplitude reflection packet (HARP) units at the base of the Red Channel-levee System of the Middle Levee Complex in Hole 936A (Flood, Piper, Klaus, et al., 1995). This interval had limited core recovery ( 325 to $375 \mathrm{mbsf}$ ); however, a few reworked siltstone and sandstone pebbles as much as $6 \mathrm{~cm}$ long were recovered in two sections (155-936A-36X-CC and 38X-CC; Fig.2), suggesting that gravel or sandy gravel was penetrated. Pirmez et al. (this volume) use the wireline log and FMS data to define a facies of gravel and scattered clasts, which appears to include our Facies 1. In addition to the example from Hole 936A, they interpret another interval of no core recovery in Hole 946A ( 240 to $260 \mathrm{mbsf}$ ) on the lower fan to be composed of gravel or pebble conglomerate. Unfortunately, the interval of no recovery in Hole 936A from which the pebbles (Fig. 2) were recovered ( 325 to $375 \mathrm{mbsf})$ was below the interval logged in this hole. The abundance of this facies is poorly constrained because some intervals of no recovery in other holes might also represent thick, coarse-grained intervals. Wireline log data are not available to interpret many of the cored intervals with no recovery.

\section{Facies 2: Medium- to Thick-Bedded Disorganized Sand-Massive} or Structureless to Chaotic with Deformation and Clasts

Facies 2 was widely recovered in some portions of the fan and, with the possible exception of Facies 1, represents the coarsest (up to very coarse sand) and thickest (up to $12 \mathrm{~m}$ ) beds encountered (Figs. 3, 4; Pirmez et al., this volume). In general, the grain size of these sand beds ranges from fine to medium (Figs. 3B-D, 4C, F, G), but many beds contain poorly sorted medium to coarse sand (Figs. 3A, 4A-D). Some beds appear massive or structureless (Fig. 3), commonly exhibiting apparent flow-in during coring or disruption caused by gas escaping on recovery (Shipboard Scientific Party, 1995c); however, many beds contain numerous large, irregularly shaped mud clasts of various sizes (Fig. 4), especially in their basal intervals. Some coarse sand beds also contain scattered granules and pebbles of quartz or rock (Fig. 3A). Wood fragments as large as a few centimeters in length occur in some beds (Fig. 3B). Deformation and/or clastic injection are rarely observed (Fig. 4G). Bedding structures such as normal or inverse grading, parallel- and cross-stratification, and convolute laminae are not present (i.e., Bouma divisions are not observed). In some instances, the very topmost parts of some of the sand beds of Facies 2 appear to be normally graded; however, it is uncertain if these graded intervals represent the same depositional events that deposited the underlying intervals of Facies 2. For example, it is difficult to explain why thick intervals with numerous mud clasts of variable size are randomly scattered in the sand matrix and are not also graded (e.g., Fig. 4).

\section{Facies 3: Thin- to Thick-Bedded Organized Sand (Includes Grading, Parallel-Stratification, and Cross-Stratification)}

Organized sand beds displaying a variety of bedding structures are quite common in cored sandy intervals throughout the fan (Figs. $5,6)$. Most beds are of thin to medium thickness, but thick beds are also common. Normally graded beds are abundant and are generally composed of medium or fine sand, which commonly grades upward into silt or clay (Figs. 5B-F, 6C, D). Graded beds of coarse sand are less common (Fig. 5A). A few beds show inverse grading from their bases upward for a few centimeters, then become normally graded upward to the top of each bed. Most graded beds have sharp, irregular, or scoured bases and transitional upper contacts (Figs. 5, 6). A few beds contain rare mud clasts near their bases (Fig. 5C), and others contain intervals of bedded organic detritus (Fig. 5D-F). Many beds of fine sand show cross-stratification (Fig. 6). Some of these crossstratified beds also exhibit normal grading (Fig. 6B-D). Cross-strati- 
A

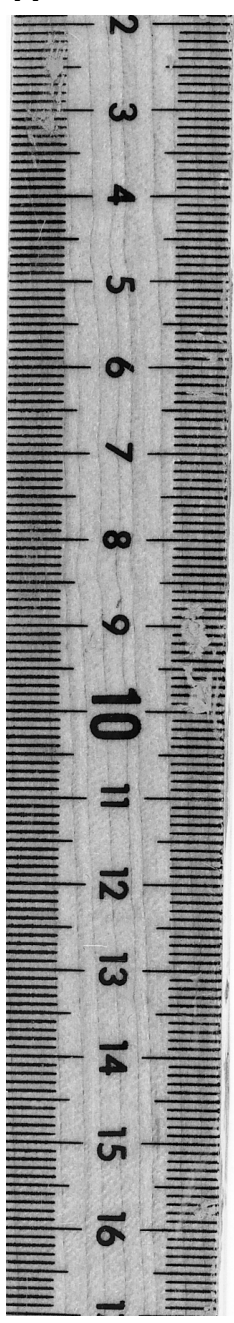

B

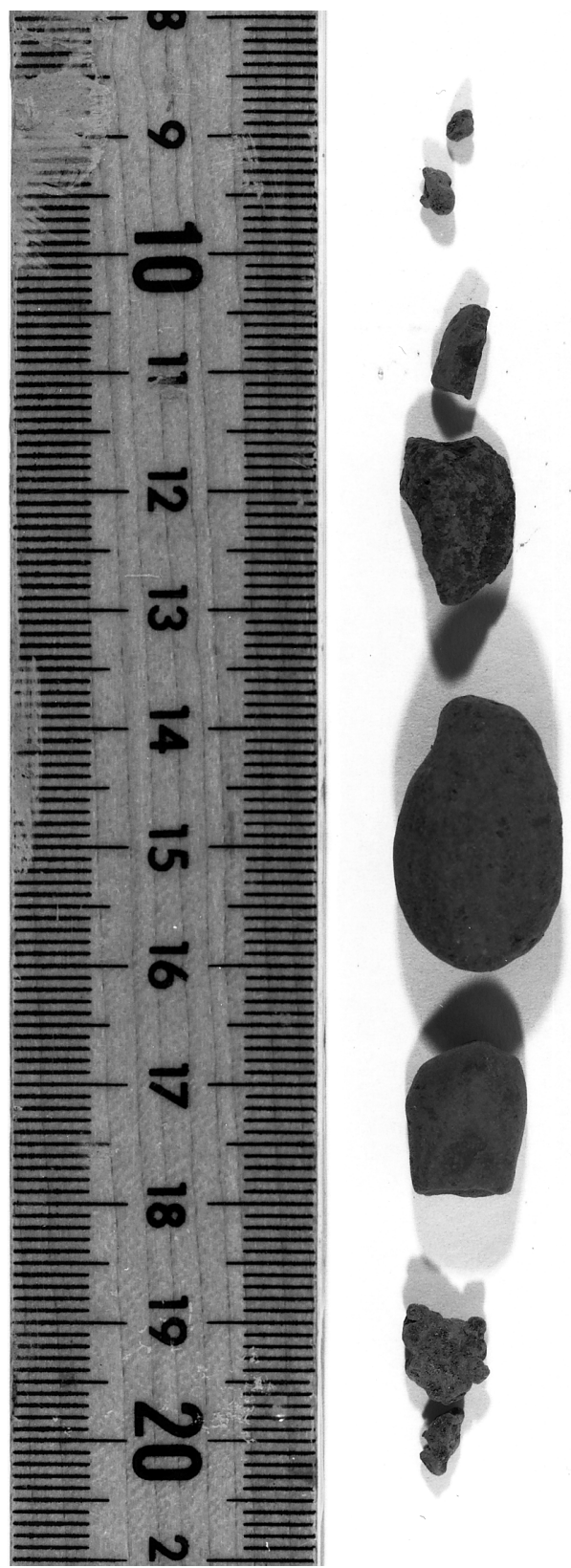

Figure 2. Examples of Facies 1 consist of medium- to thick-bedded, disorganized gravel and sandy gravel. Lithic pebbles recovered from deposits are interpreted to be HARP units at the base of the Red Channel-levee System. Core recovery was very poor in this interval; however, these pebbles suggest a gravel or sandy gravel facies. A. Olive-colored siltstone pebbles and a sandstone pebble (top center; interval 155-936A-36X-CC, 2-17 cm). B. Olive-colored siltstone pebbles (interval 155-936A-38X-CC, 8-21 cm). Note that in this and the following figures, the captions provide correlations of facies examples to seismic (e.g., HARs and HARPs) and depositional (levees, channels, and MTDs) units within the fan as presented in the specific site chapters of Flood, Piper, Klaus, et al. (1995).

fication is observed in many thin beds and laminae (Fig. 6); parallelstratification is much less common. Consequently, in Facies 3 beds, Bouma divisions $\mathrm{T}_{\mathrm{a}}, \mathrm{T}_{\mathrm{c}}$, and $\mathrm{T}_{\mathrm{e}}$ are the most prevalent; whereas $\mathrm{T}_{\mathrm{b}}$ and $\mathrm{T}_{\mathrm{d}}$ divisions are rarer.

\section{Facies 4: Laminated to Medium-Bedded Disorganized or Structureless Silt}

Facies 4 consists of silt beds and laminae that are structureless, except for textures generated by gas escaping during recovery (Fig. 7). The silty components of Facies 4 mainly occur in thin beds and lam- inae (Fig. 7B-D), although beds of medium thickness rarely occur (Fig. 7A). Piper and Deptuck (this volume) review fine-grained turbidite units in detail because of their volumetric significance in overbank flows. Our Facies 4 includes facies 1 and 2 of their 12 finegrained turbidite classification.

\section{Facies 5: Laminated to Thin-Bedded Organized Silt (Includes Grading, Parallel-Stratification, and Cross-Stratification)}

Organized silt beds and laminae displaying various types of bedding structures are probably the most abundant granular beds cored 
A

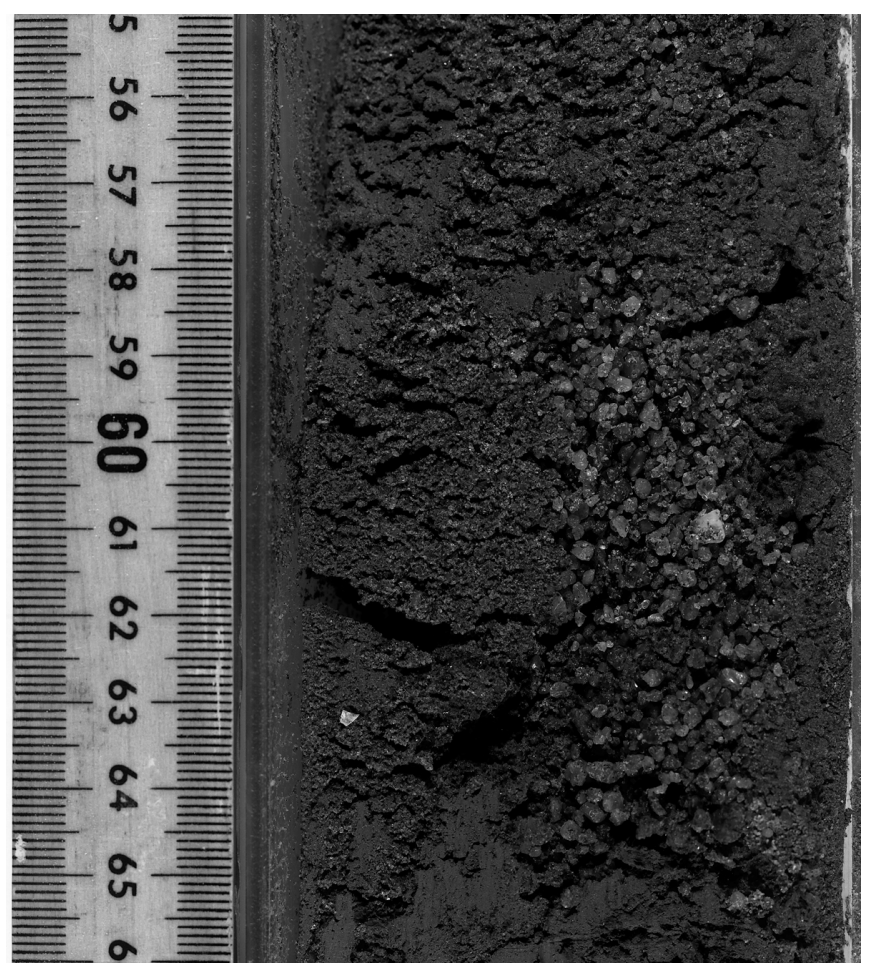

B

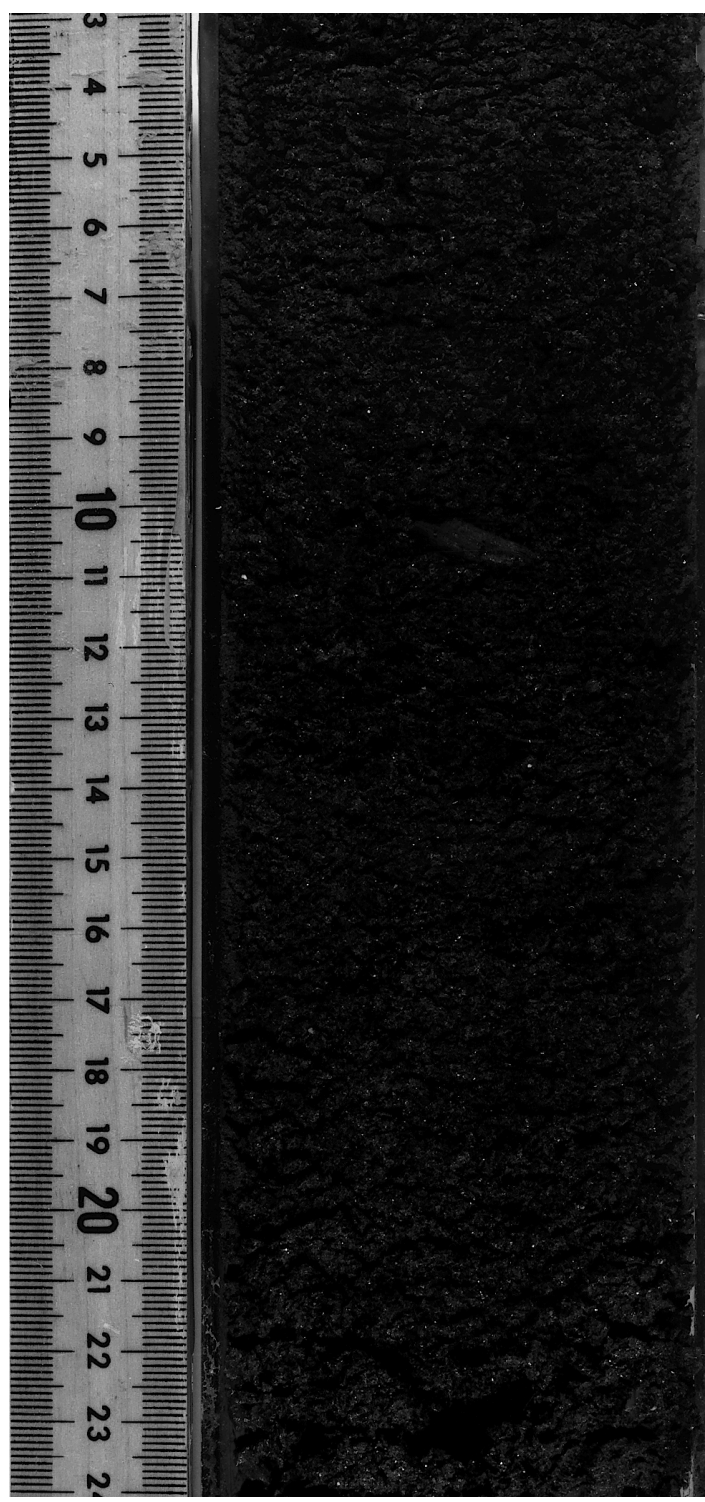

Figure 3. Examples of Facies 2 consist of medium- to thick-bedded, disorganized sand, including massive or structureless sands. A through C are from the axis (interpreted to be HAR units) of a channel segment in a cutoff meander of the Amazon Channel. A. Disturbed, poorly sorted, very coarse sand from the lower portion of an 18-m-thick structureless sand bed containing 1-2 mm quartzose sand, some granules, and rare pebbles to 0.5 cm (interval 155-934B-9H-5, 55-66 $\mathrm{cm}$ ). B. Fine, gas-disturbed sand with disseminated organic detritus (wood fragment at 10-11 cm; interval 155-934A-3H-3, 3-24 cm).

in the fan (Fig. 8). This facies consists almost exclusively of thin beds and laminae and includes facies 3 of Piper and Deptuck (this volume). Normal grading occurs in some beds (Fig. 8D, E), but paralleland cross-laminations are the most common bedding structures (Fig. 8). Climbing ripples were rarely observed in this Facies 5. Muddraped (starved) ripples are observed locally. Most beds have sharp, locally scoured bases and sharp or transitional upper contacts. In Facies 5, Bouma divisions $\mathrm{T}_{\mathrm{b}-\mathrm{d}}$ are most common; thin laminae of $\mathrm{T}_{\mathrm{a}}$ are less common.

\section{Facies 6: Very Thin ( 1 mm) Regular Silt and Mud Laminae}

Facies 6 is composed of thin intervals of numerous, very thin (1$2 \mathrm{~mm}$ thick) silt and mud laminae (Fig. 9). These intervals of Facies 6 occur interbedded with Facies 3, 5, and 7, and in some intervals occur just above thicker graded beds of Facies 3 and 5 (e.g., Fig. 9A). It is therefore possible that the laminae of Facies 6 were deposited by the same flow events that deposited the underlying thicker beds. No bedding structures are apparent in the silt laminae of this facies. Facies 6 includes the facies 4 of Piper and Deptuck (this volume).

\section{Facies 7: Irregular or Discontinuous Silt Laminae}

Facies 7 consists of organized silt laminae quite similar to those of Facies 5, except that individual laminae of Facies 7 are generally of irregular thickness and are commonly discontinuous in lateral extent across the core face (Fig. 10). Most laminae of this facies show cross-stratification, commonly with mud-draped laminae, and have sharp bases and tops. Piper and Deptuck (this volume) distinguish four fine-grained turbidite facies (their facies 5 through 8) within $\mathrm{Fa}$ cies 7. 

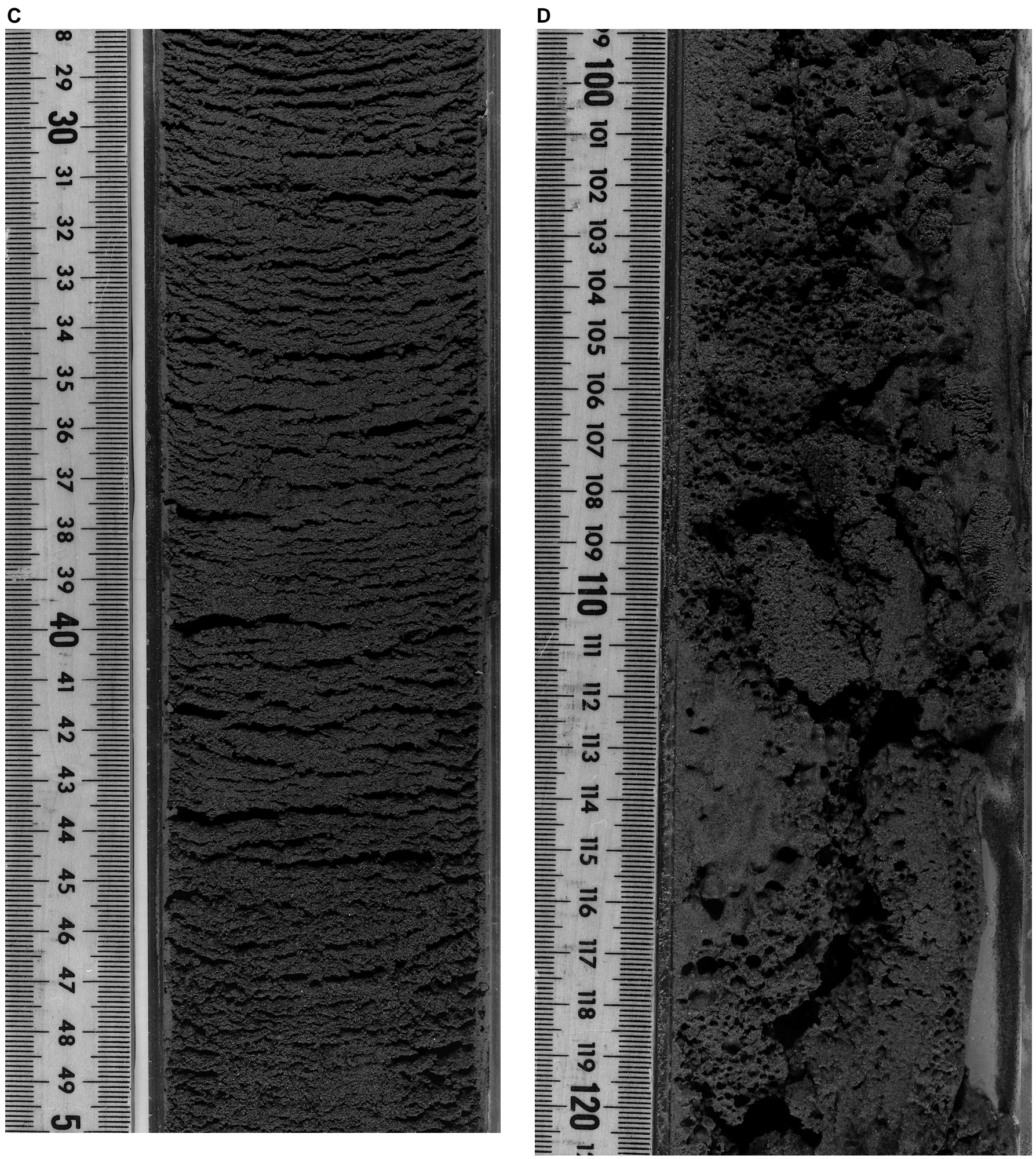

Figure 3 (continued). C. Structureless, gas-disturbed fine sand (interval 155-934B-3H-5, 28-50 cm). D. Gas-disrupted, fine sand from a 2-m-thick bed in lower fan deposits (interpreted to be from a depositional lobe deposit). The honey-comb structure may have been caused by the presence of frozen gas hydrate (interval 155-945A-7H-3, 99-121 cm). 
A

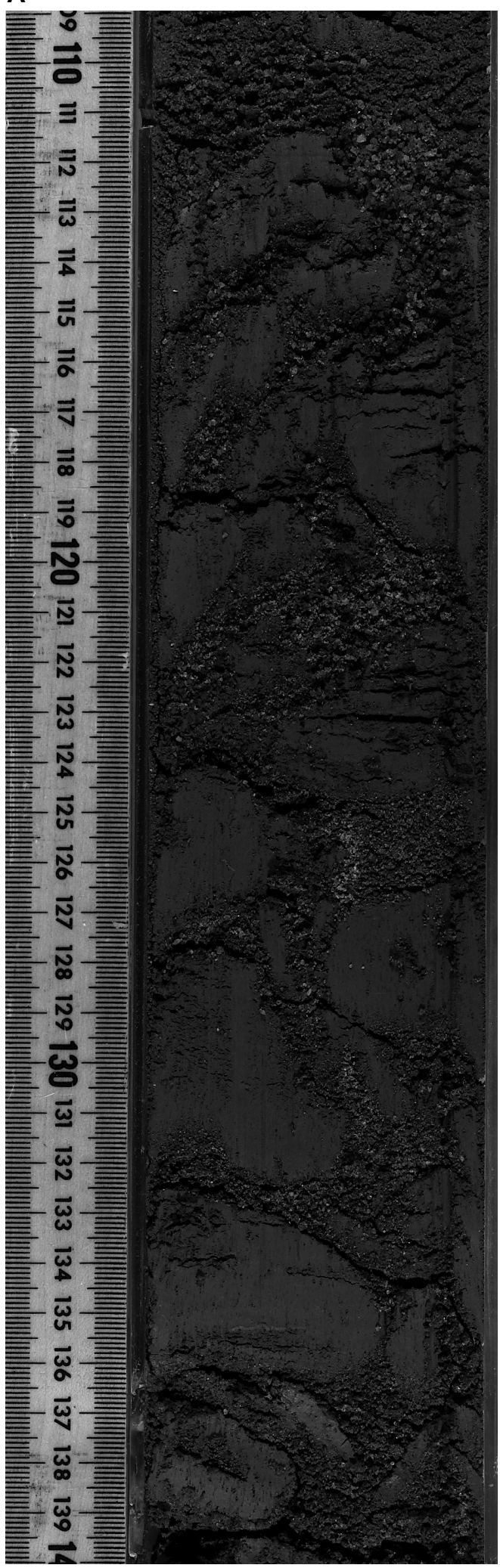

B

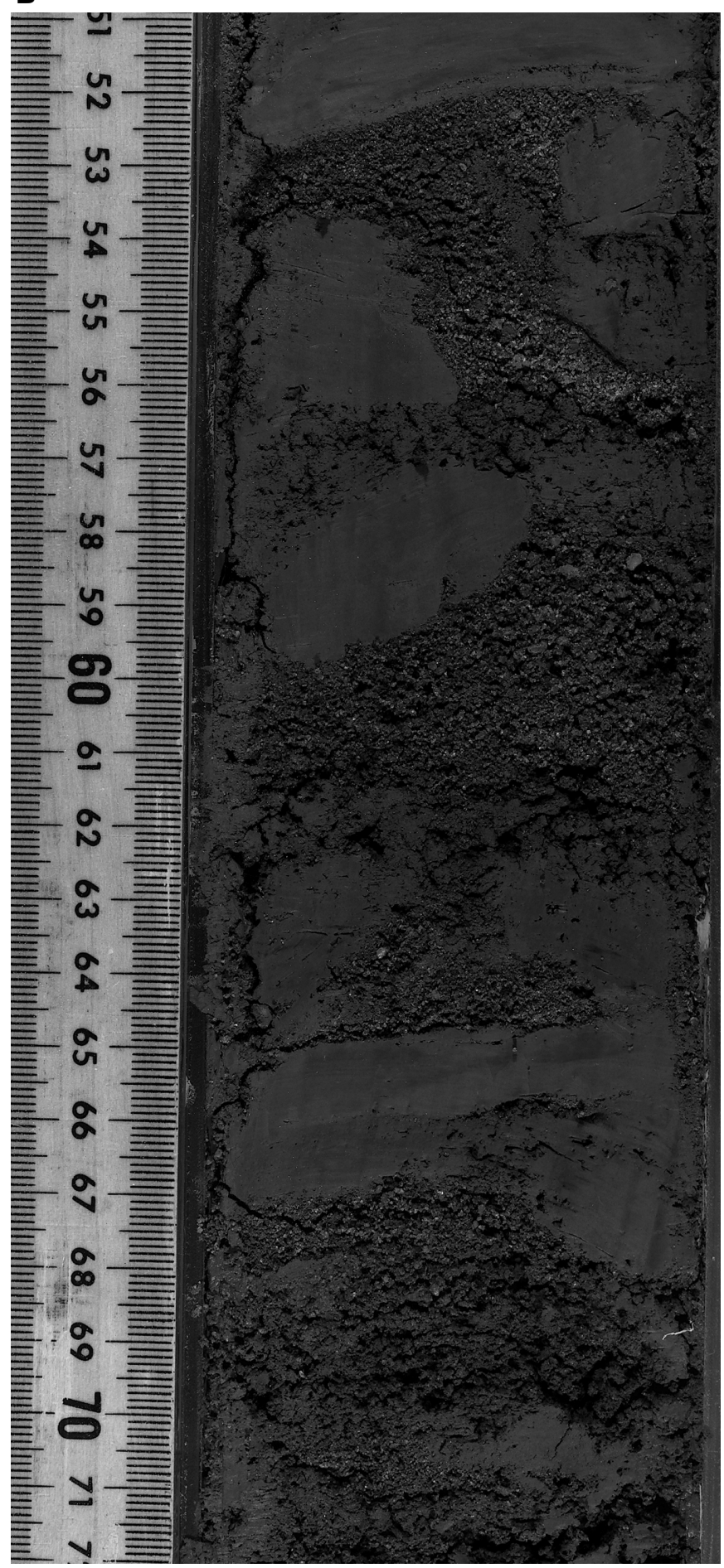

Figure 4. Examples of Facies 2 consist of medium- to thick-bedded disorganized sand, including chaotic sands with deformation and clasts from five different drill sites. A. Mud clasts in a fine- to coarse-sand matrix of a very thick sand bed contained in buried channel-fill deposits (probably from a HAR unit) from a cutoff meander along the Amazon Channel (interval 155-934A-10H-6, 109-140 cm). B. Irregularly shaped mud clasts in a poorly sorted (fine to coarse), several meter thick sand bed from lower fan deposits (interpreted to be from a depositional lobe deposit; interval 155-946A-21X-3, 51-72 cm). 


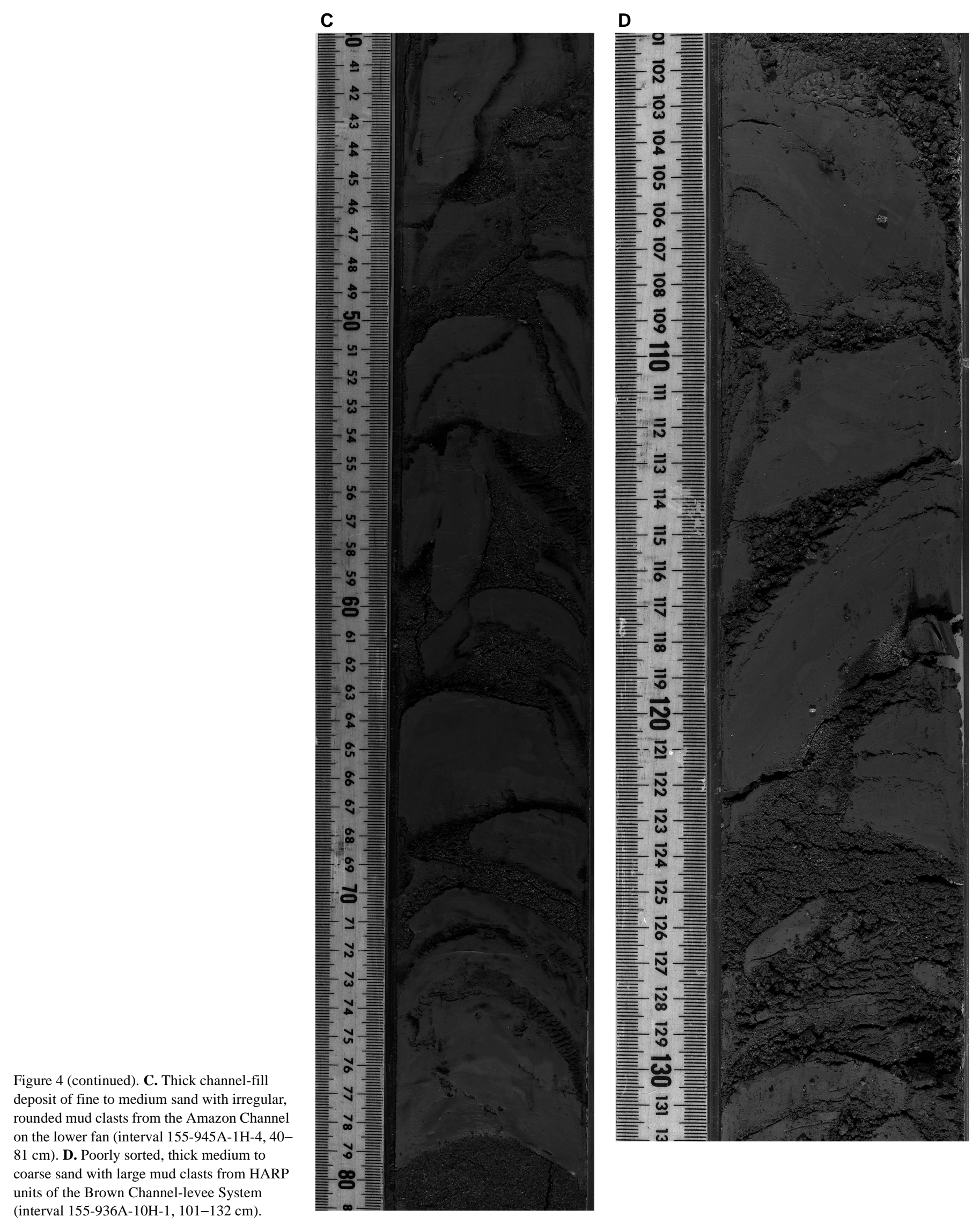


$\mathbf{E}$

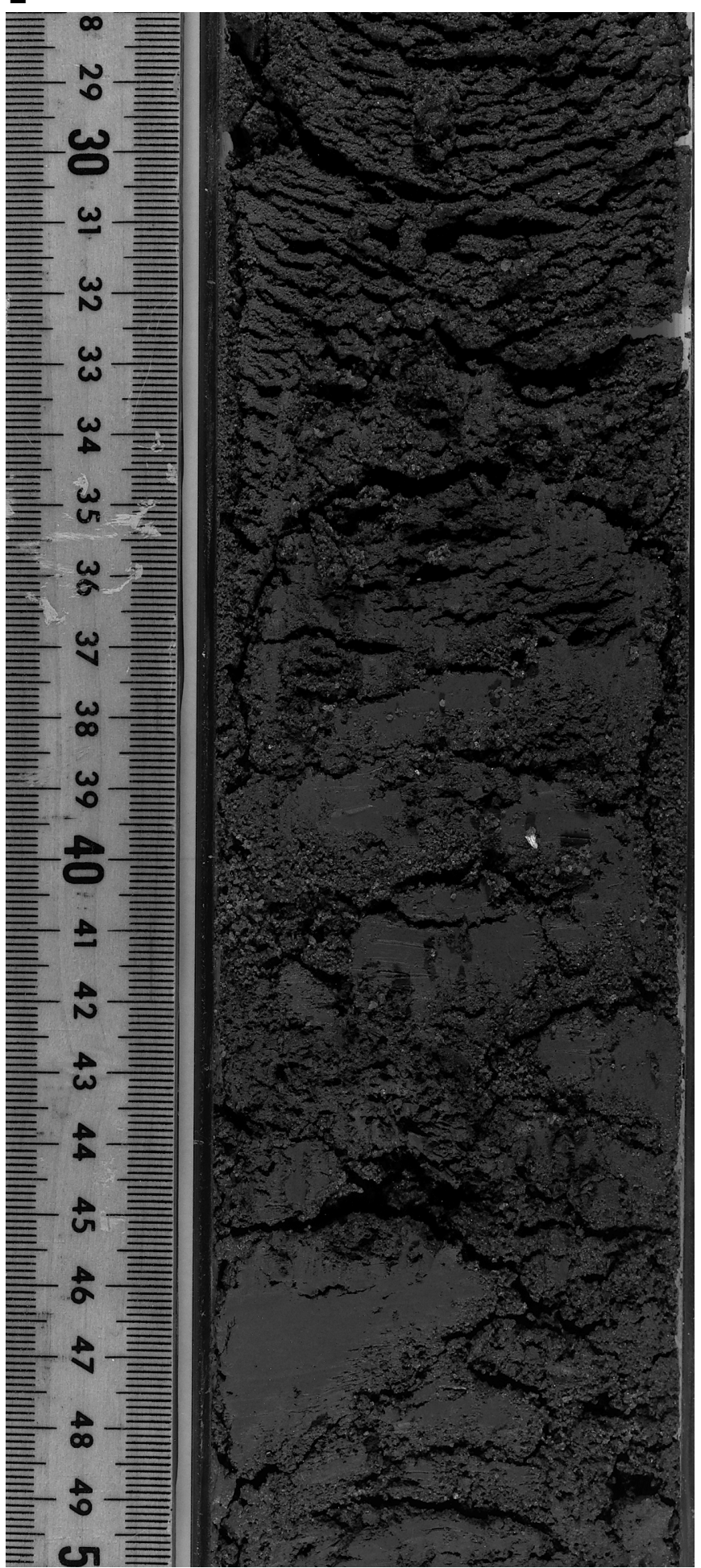

$\mathbf{F}$

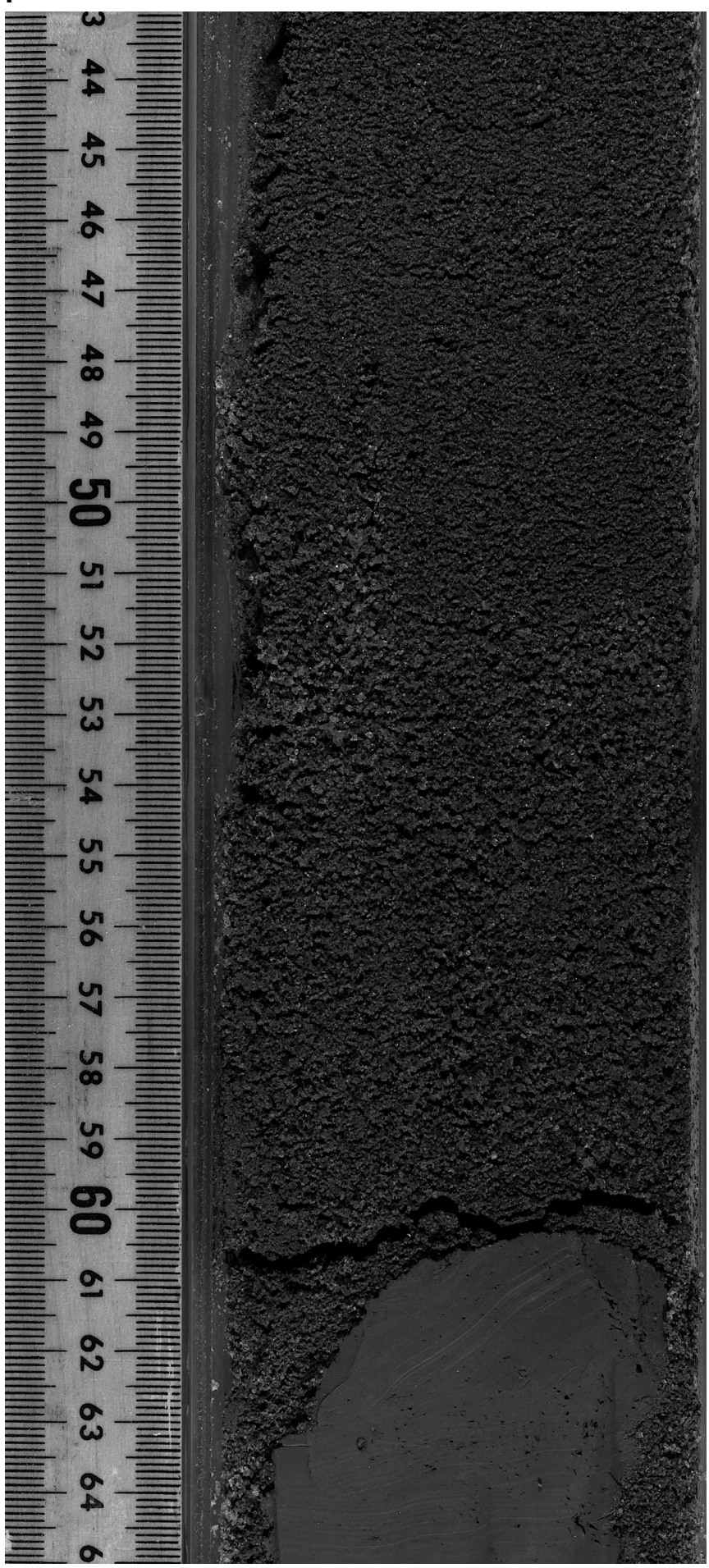

Figure 4 (continued). E. Thick bed of poorly sorted fine to coarse sand with mud clasts recovered from channel-fill deposits in the Amazon Channel on the middle fan (interval 155-943A-8X-1, 28-50 cm). F. Thick bed of fine to medium sand from channel-fill deposits in a cutoff meander of the Amazon Channel (interval 155-934B-11H-1, 43-65 cm). . 
G

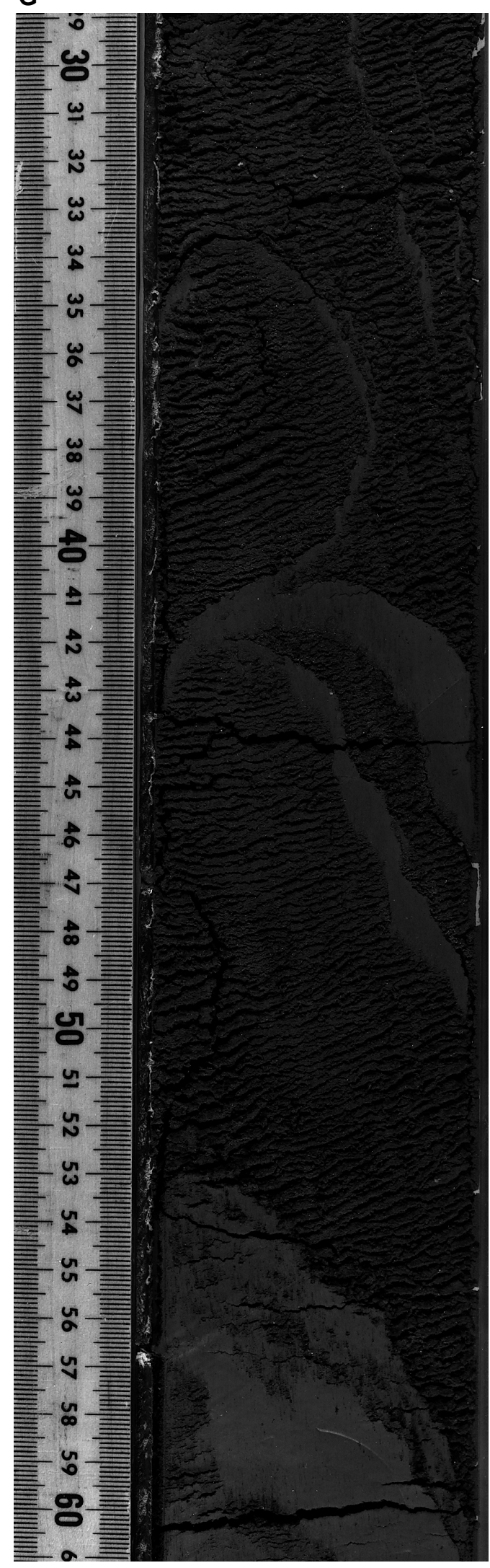

Figure 4 (continued). G. Deformed clasts or possibly injected mud in silty sand in an MTD within the channel of a cutoff meander along the Amazon Channel (interval 155-934A-7H-5, 29-61 cm).

\section{Facies 8: Color-Banded and/or Color-Mottled Silt and Mud Laminae and Thin Beds}

Facies 8 consists of intervals of silt and mud laminae and thin beds in which the silt layers are lightly to intensely color mottled and/or color banded (Fig. 11). In most intervals, the muds and silts are various shades of gray, and the mottling and banding have been produced by the presence of black hydrotroilite staining (Flood, Piper, Klaus, et al., 1995; Shipboard Scientific Party, 1995c). Commonly, entire silt laminae and beds are hydrotroilite stained (Fig. 11A-C). Color mottling may be related to bioturbation, hydrotroilite speckles or micronodules, or discontinuous color bands of hydrotroilite. In some instances, a single silt lamina displays internal color lamination caused by selective hydrotroilite staining of laminations (Fig. 11D). Facies 8 includes facies 6 through 8 of Piper and Deptuck (this volume).

\section{Facies 9: Color-Mottled and/or Color-Banded Mud and Clay}

Facies 9 consists of intervals of gray mud of various shades that are lightly to intensely color mottled and/or color banded (Figs. 12, 13) and corresponds to facies 9 of Piper and Deptuck (this volume). In most intervals, the mottling and banding have been produced by the presence of black hydrotroilite staining. Rarely, entire intervals of core are stained black (Fig. 12A). More commonly, color mottling takes the form of irregular blotches (Fig. 12B), faint speckles, or discontinuous pseudolaminae related to bioturbation (Fig. 12C), or micronodules of hydrotroilite. Color bands are generally $<1 \mathrm{~cm}$ thick (Fig. 13) and commonly discontinuous.

\section{Facies 10: Homogeneous, Structureless Mud and Clay}

Facies 10 consists of thick intervals of homogeneous, structureless gray mud and clay. Colors range from medium gray to dark gray or dark olive gray to black. Intervals of this facies are up to tens of meters thick. Facies 10 is commonly interbedded with Facies 11 and 12.

\section{Facies 11: Disorganized Pebbly or Gravelly Mud and Sandy Mud}

Facies 11 consists of various shades of gray to black clay, silty clay, and sandy mud that contain randomly scattered lithic pebbles and granules (Fig. 14). Pebbles are as much as a few centimeters in diameter and are rare to common in the split-core surface. However, $\mathrm{X}$-radiographs indicate that pebbles are generally more common throughout the core section than the split-core surface suggests. For example, an X-radiograph of the core section shown in Figure 14C (Flood, Piper, Klaus, et al., 1995; fig. 14, p. 102) reveals the presence of many more pebbles than the single quartz pebble visible on the split-core surface. Most pebbles are rock fragments, mainly siltstone (Fig. 14B), sandstone (Fig. 14D), or other lithic fragments (Fig. 14A), but some are quartz (Fig. 14C). Aragonitic shell fragments of gastropods and bivalves are also common in some intervals of Facies 11. Facies 11 is commonly interbedded or associated with Facies 10 and 12 (e.g., Fig. 14D).

\section{Facies 12: Deformed to Chaotic Mud (Including Mud Clasts and/ or Dipping, Discordant, Folded, Contorted, Faulted, and/or Truncated Strata)}

Facies 12 consists of clay and silty clay of variegated color whichmainly range through shades of dark gray, dark olive gray, dark greenish gray, and black, although lighter shades of gray and other colors also occur. Textures of the clay intervals range from very soft, smooth and homogeneous to very dense and stiff. Some intervals have a shiny, greasy, or glossy appearance on the split-core surface, whereas others have a rough surface caused by dispersed sand grains. These sediments are highly deformed as a result of soft-sediment failure, deformation, and redeposition as evidenced by abrupt changes in lithology and color, structures indicative of deformation such as folds 
A

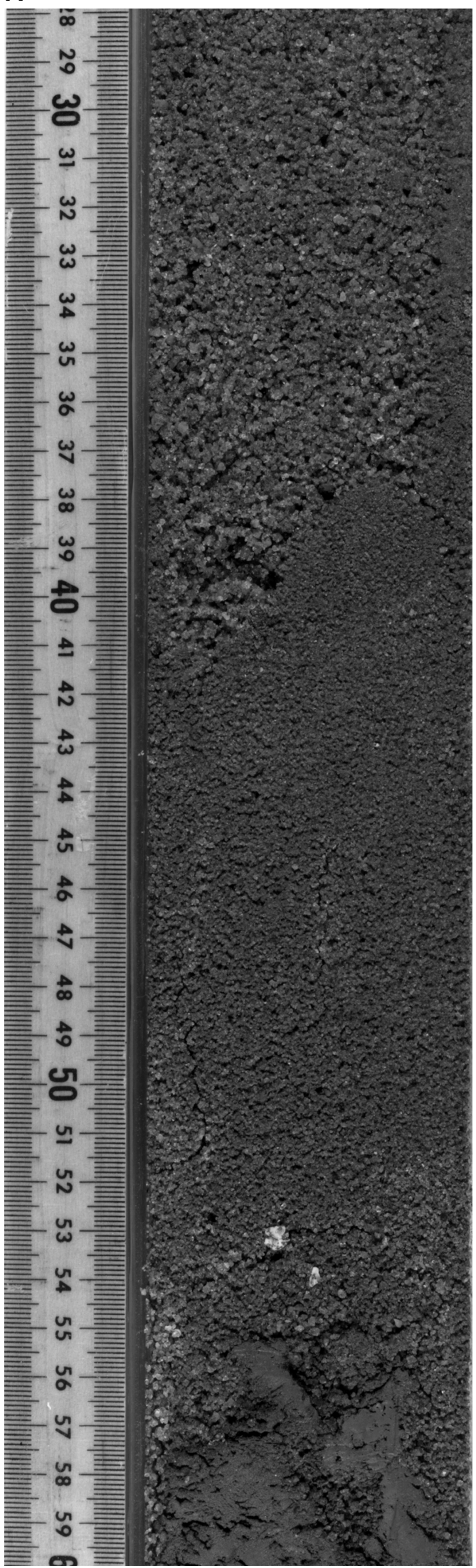

B

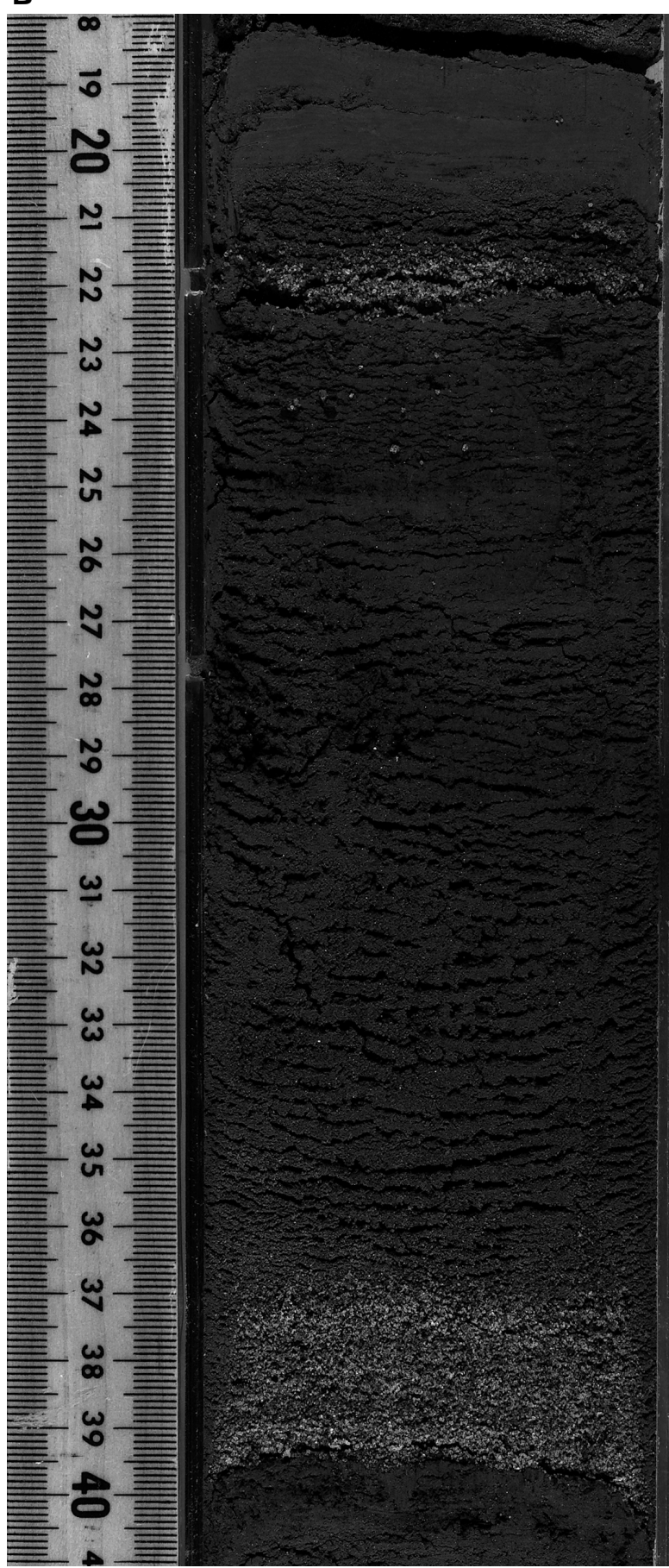

Figure 5. Examples of Facies 3 consist of thin- to thick-bedded organized sand and include normally graded beds. A. Normally graded medium to coarse sand beds from HARP units of the Brown Channel-levee System (interval 155-936A-10H-1, 28-60 cm). B. Sharp-based, normally graded bed of medium sand at the base $(39.5 \mathrm{~cm})$ to coarse silt at top from channel-fill deposits in a cutoff meander of the Amazon Channel (interval 155-934A-10H-6, 18-41 cm). 


\section{C}

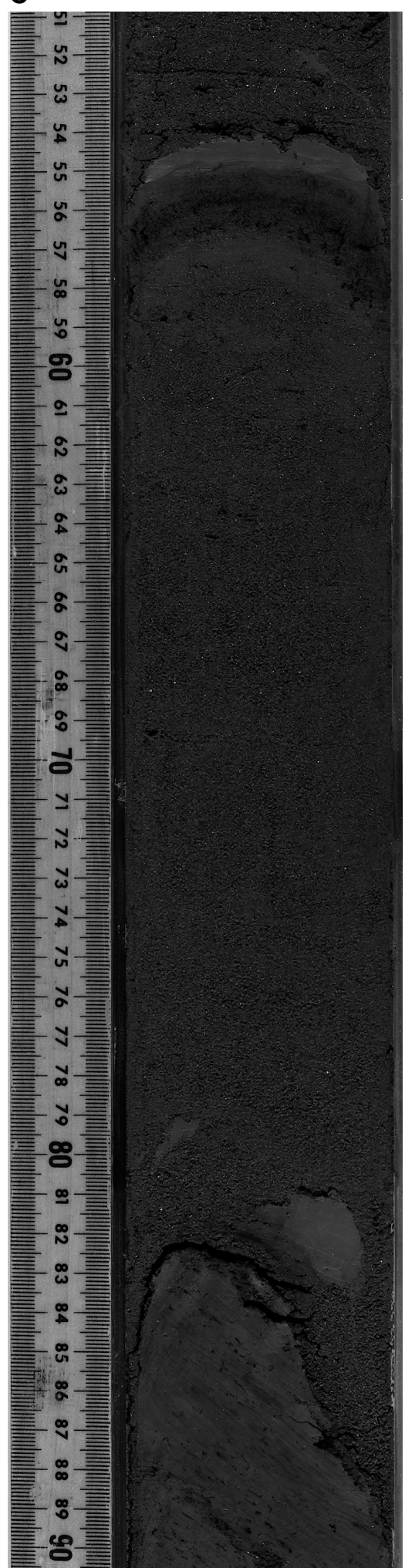

D

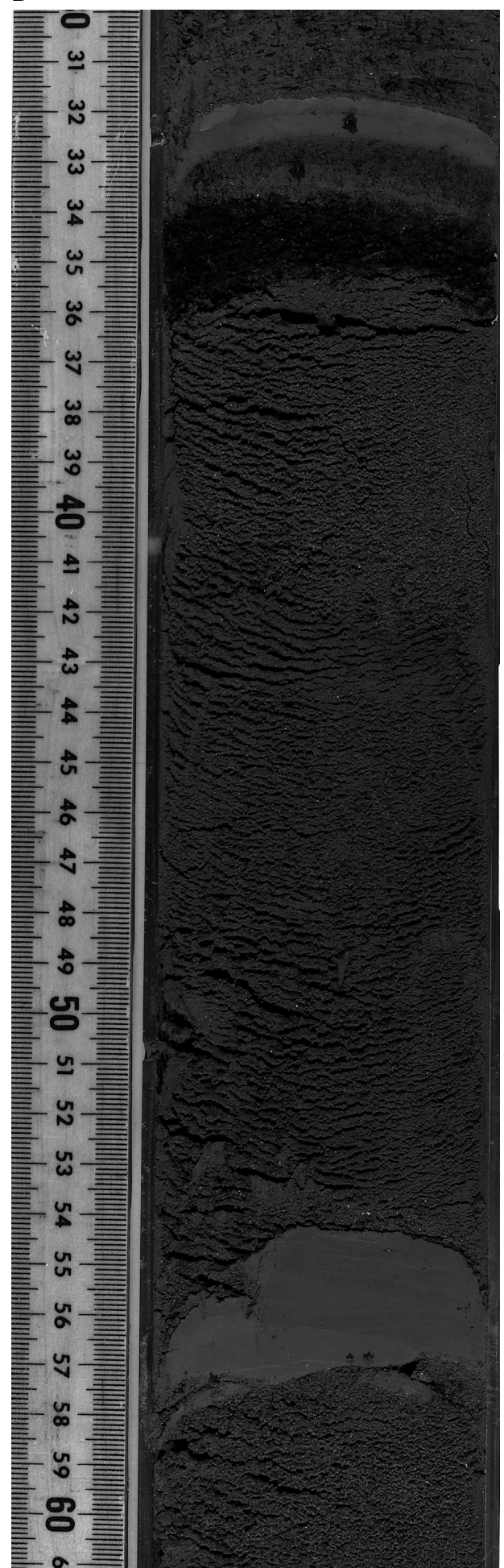

Figure 5 (continued). C. Normally graded medium-thick bed of fine sand to silt and clay from lower fan deposits (interpreted to be from a depositional lobe deposit). Mud clasts occur just above the sharp, irregular base of the bed (interval 155-945A-2H-5, 51-91 cm). D. Normally graded sand bed of medium thickness with a sharp, erosive base (54-55 cm) from lower fan deposits (interpreted to be from a depositional lobe deposit). The bed grades upward through silt into clay $(32-34 \mathrm{~cm})$. A layer of organic detritus is present from 34-36 cm (interval 155-945A-4H-5, 30-61 cm). 
E

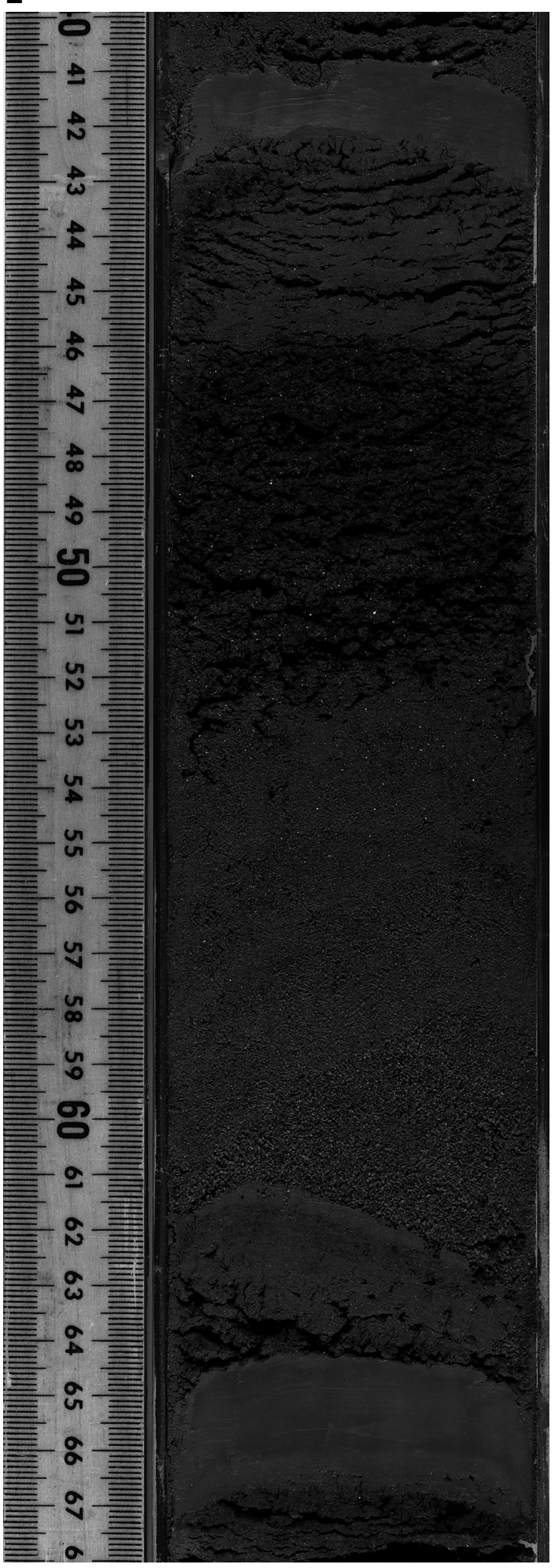

$\mathbf{F}$

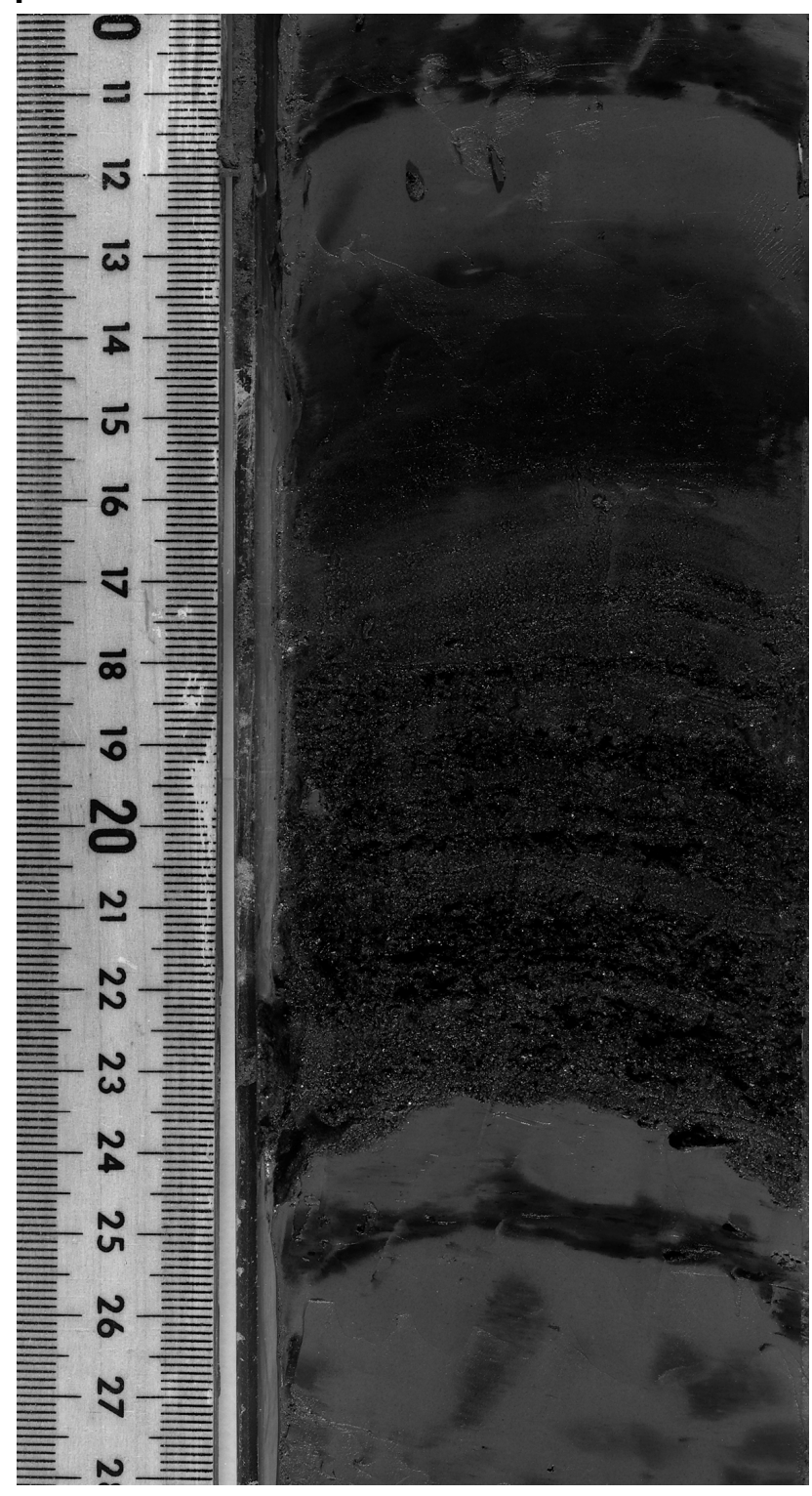

Figure 5 (continued). E. Normally graded medium-thick sand bed from lower fan deposits (interpreted to be from a depositional lobe deposit). The bed grades upward from medium sand at the base $(61-62 \mathrm{~cm})$ to clay at the top $(41 \mathrm{~cm})$. Organic detritus occurs from 52 to $46 \mathrm{~cm}$. Origin of the diagonal contact between medium and fine sand $(59-61 \mathrm{~cm}$ ) is uncertain (interval 155-945A-7H-1, 40-68 cm). F. Normally graded fine sand to silt with leaf fragments along the base and dark bands of organic detritus at several levels from lower fan deposits (interpreted to be from a depositional lobe deposit; interval 155-946A-1H-3, 10-28 cm). 
A

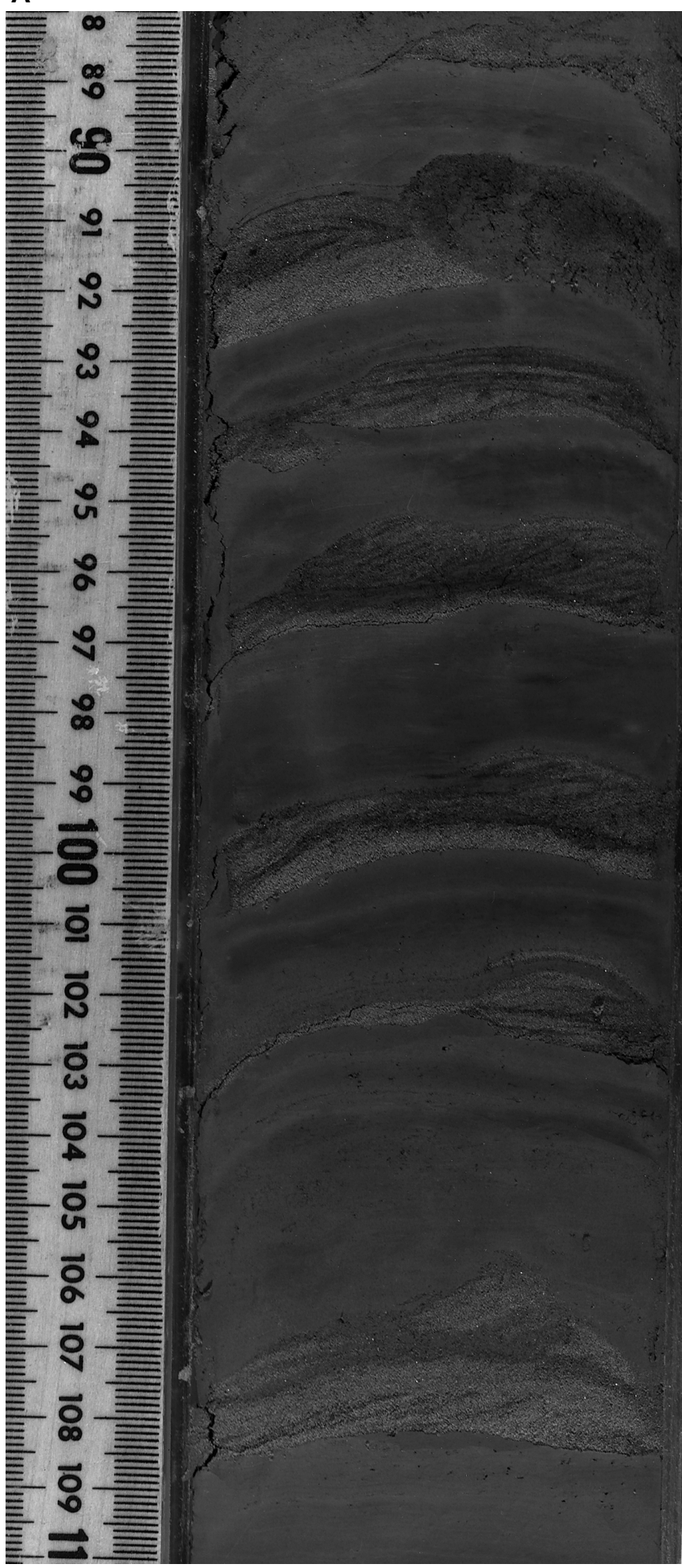

B

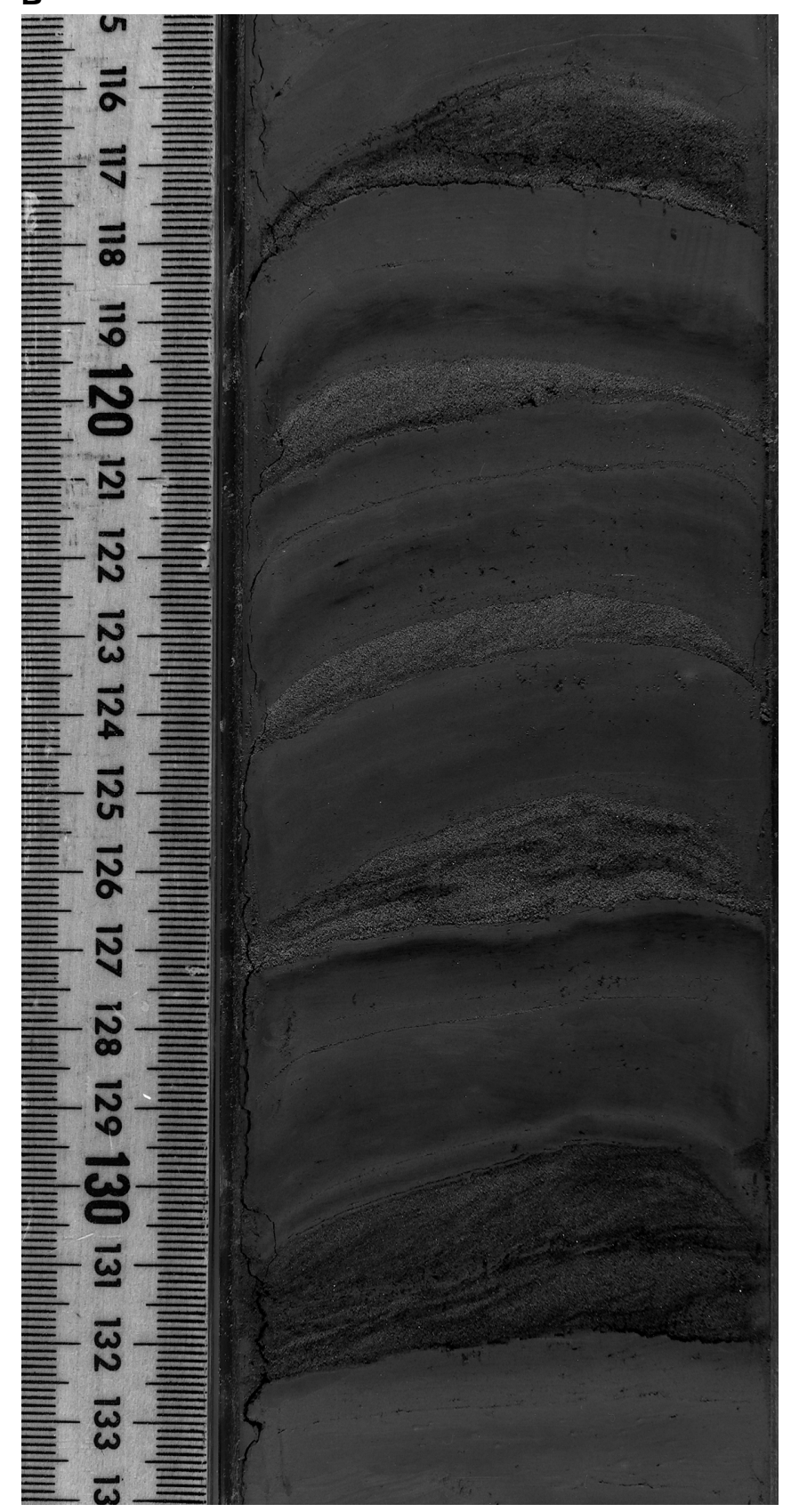

Figure 6. Examples of Facies 3 consist of thin- to thick-bedded organized sand, including cross-stratified and normally graded beds. A. Cross-laminated, wavy beds and laminae of very fine sand from levee deposits. Note finely laminated mud immediately above some beds (e.g., 93 and $102 \mathrm{~cm}$ ), "fading" ripple lamination at $99 \mathrm{~cm}$, and burrow truncation at 90-92 cm (interval 155-942A-6H-5, 88-110 cm). B. Cross-laminated, wavy beds and laminae of very fine sand from levee deposits. Note finely laminated mud immediately above most of the rippled division and "fading" ripple lamination at $116 \mathrm{~cm}$ (interval $155-942 \mathrm{~A}-6 \mathrm{H}-4$, $115-134 \mathrm{~cm})$. 
C

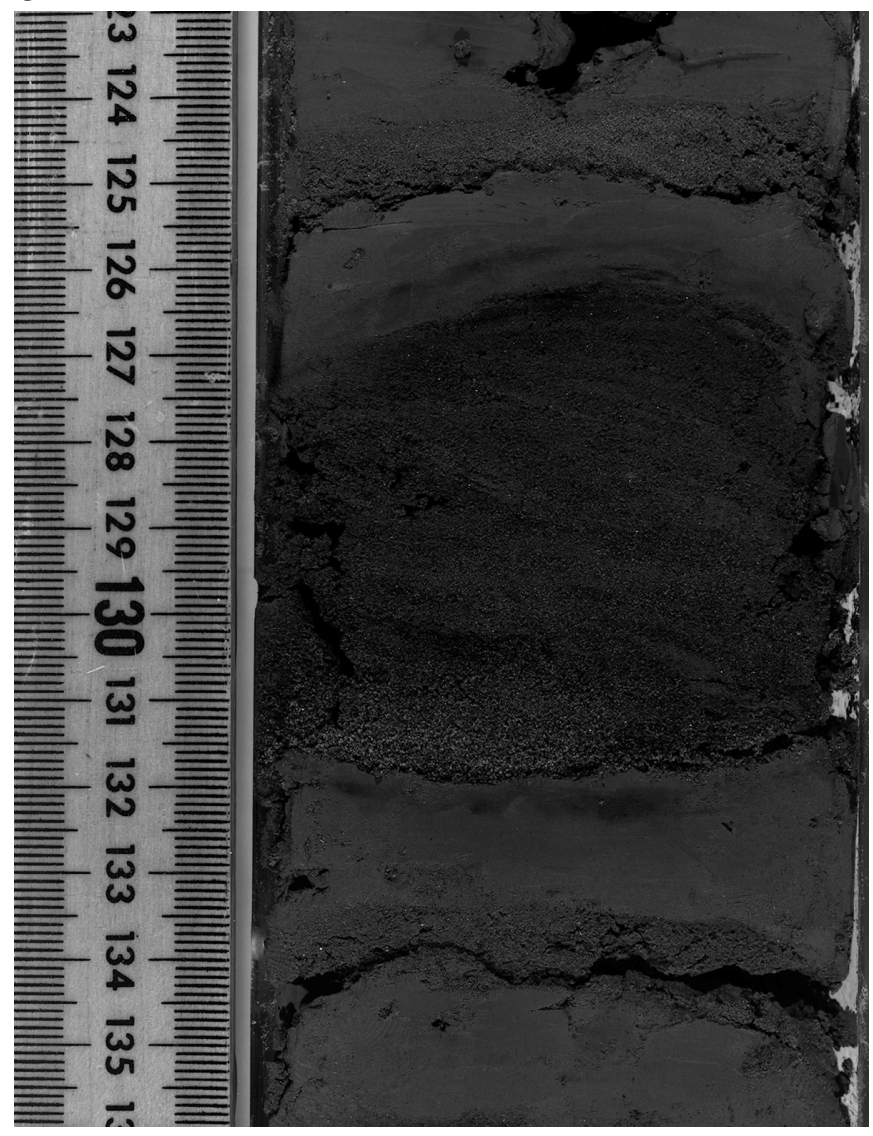

D

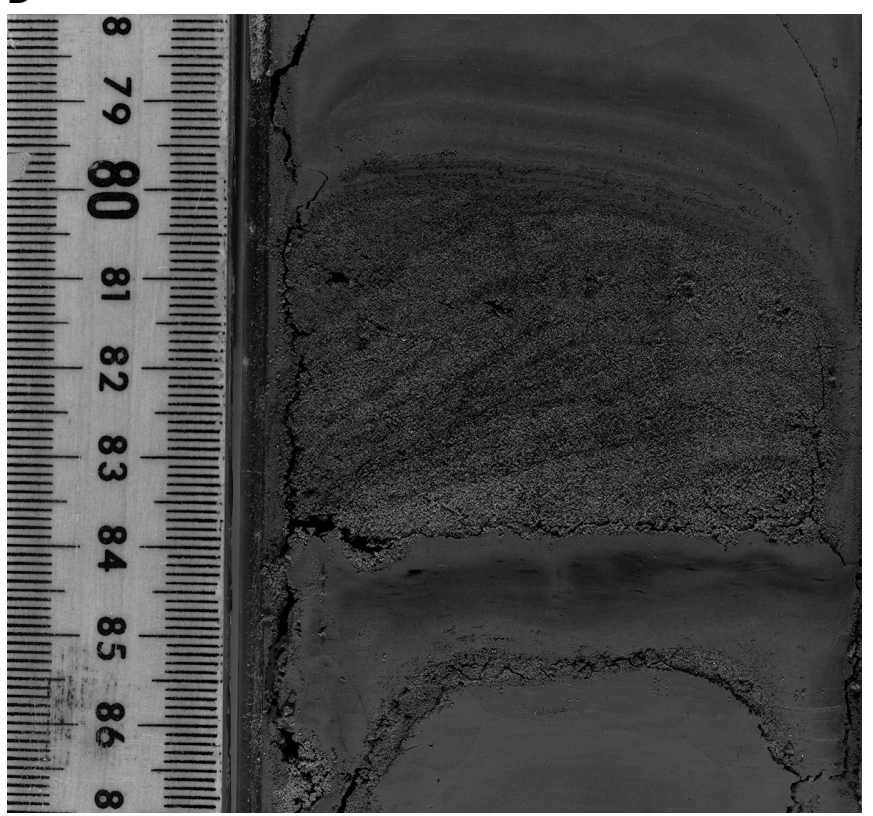

E

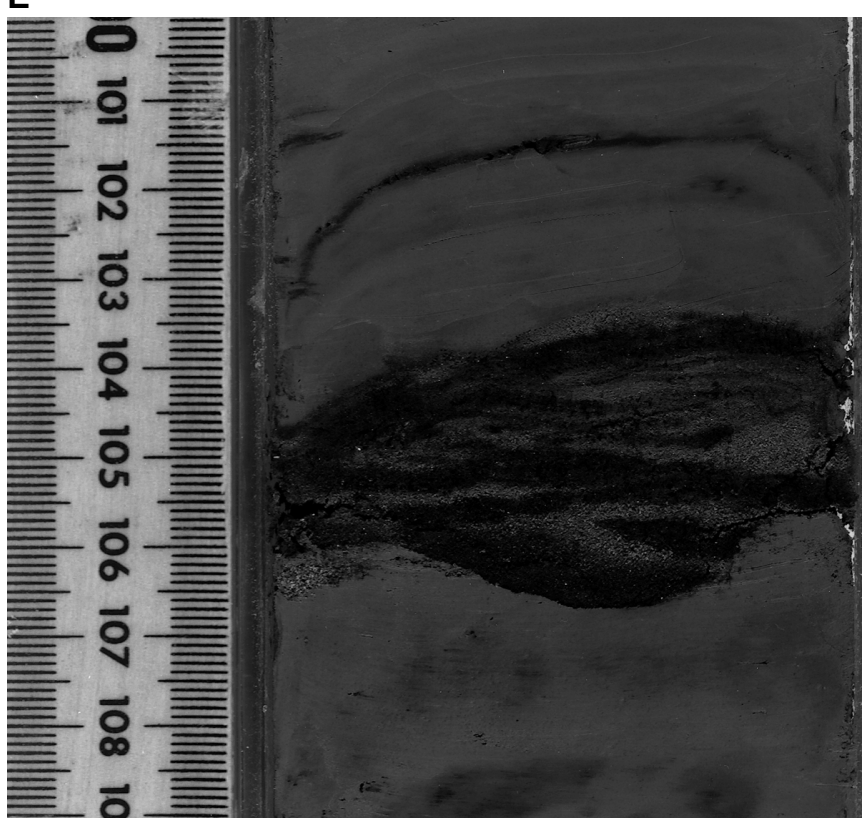

Figure 6 (continued). C. Normally graded, cross-laminated thin sand and silt bed (125.5-132 cm) from levee deposits (155-942C-4H-2, 123-136 cm). D. Normally graded, cross-laminated thin sand and silt bed $(80-84 \mathrm{~cm}$ ) from levee deposits (interval $155-942 \mathrm{C}-3 \mathrm{H}-6,78-87 \mathrm{~cm})$. E. Cross-laminated thin bed of very fine sand from levee deposits. The basal scour may be a flute cast (interval 155-942A-4H-1, 100-109 cm).

and faults, discordant stratal relationships between dipping laminae, beds and lithologic contacts, and the occurrence of mud clasts of various sizes (Figs. 15-17). In many examples of this facies, further deformation occurred during the coring process that tended to obscure the in situ structure of the sediment (Shipboard Scientific Party, 1995c).

Some intervals of Facies 12 contain mud clasts of various sizes, colors, shapes, textures, and compositions (Fig. 15). Some intervals are clast supported with little apparent matrix (Fig. 15C, D), whereas other intervals contain isolated clasts supported by a clay matrix (Fig. $15 \mathrm{~A}, \mathrm{~B})$. Sizes range from centimeter scale, which are clearly recog- nizable in the cores, up to meter scale or larger clasts or blocks that span more than one core section. Some of the deformed chaotic core sections shown in Figures 16 and 17 may actually be portions of larger clasts or blocks. Clasts of lithified sediment including siltstone, sandstone, and rock pebbles similar to those found in Facies 11 are rare in Facies 12. Small clasts of unlithified silt and sand occur in a few intervals that appear to be laminae and beds of Facies 3 and 5, which have been disrupted and deformed. Shell fragments including echinoderms, gastropods, pteropods, ostracodes, and other unidentified aragonitic fragments occur in some intervals. Wood fragments up to a few centimeters long are rare. 
A

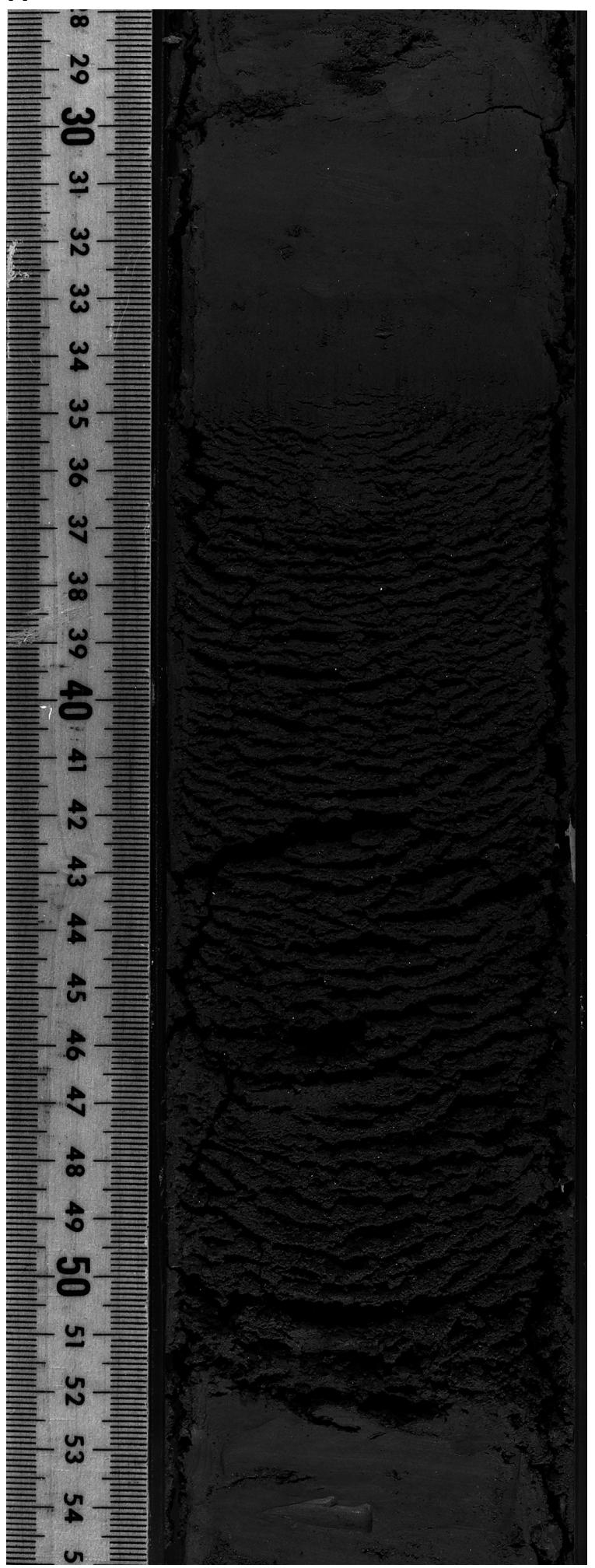

B

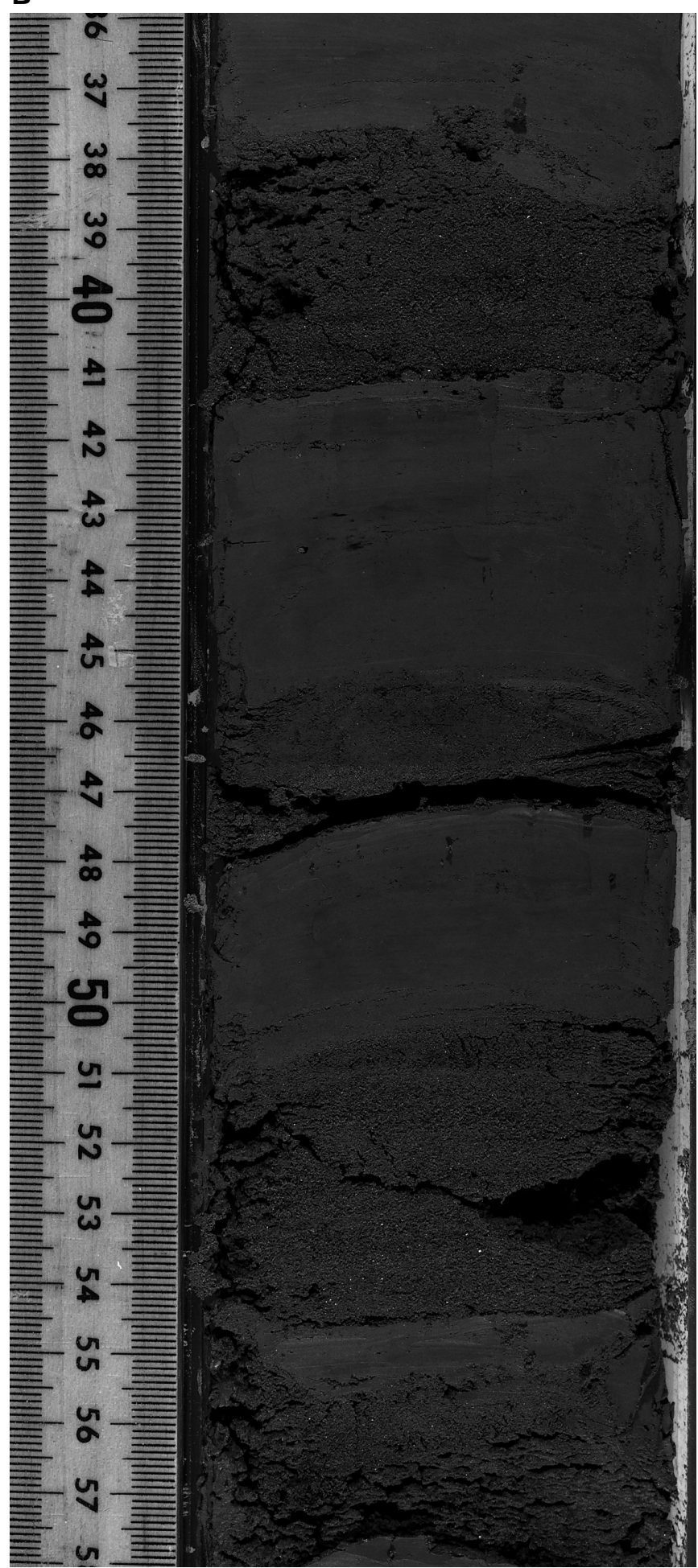

Figure 7. Examples of Facies 4 consist of laminated to medium-bedded disorganized or structureless silt. A. Medium-thick bed of silt disrupted by gas from levee deposits of the Channel-levee System 5 interval (155-931B-15X-2, 28-55 cm). B. Structureless, closely spaced, thin coarse silt beds from levee deposits of the Yellow Channel-levee System (interval 155-937C-6H-3, 36-58 cm). 
C

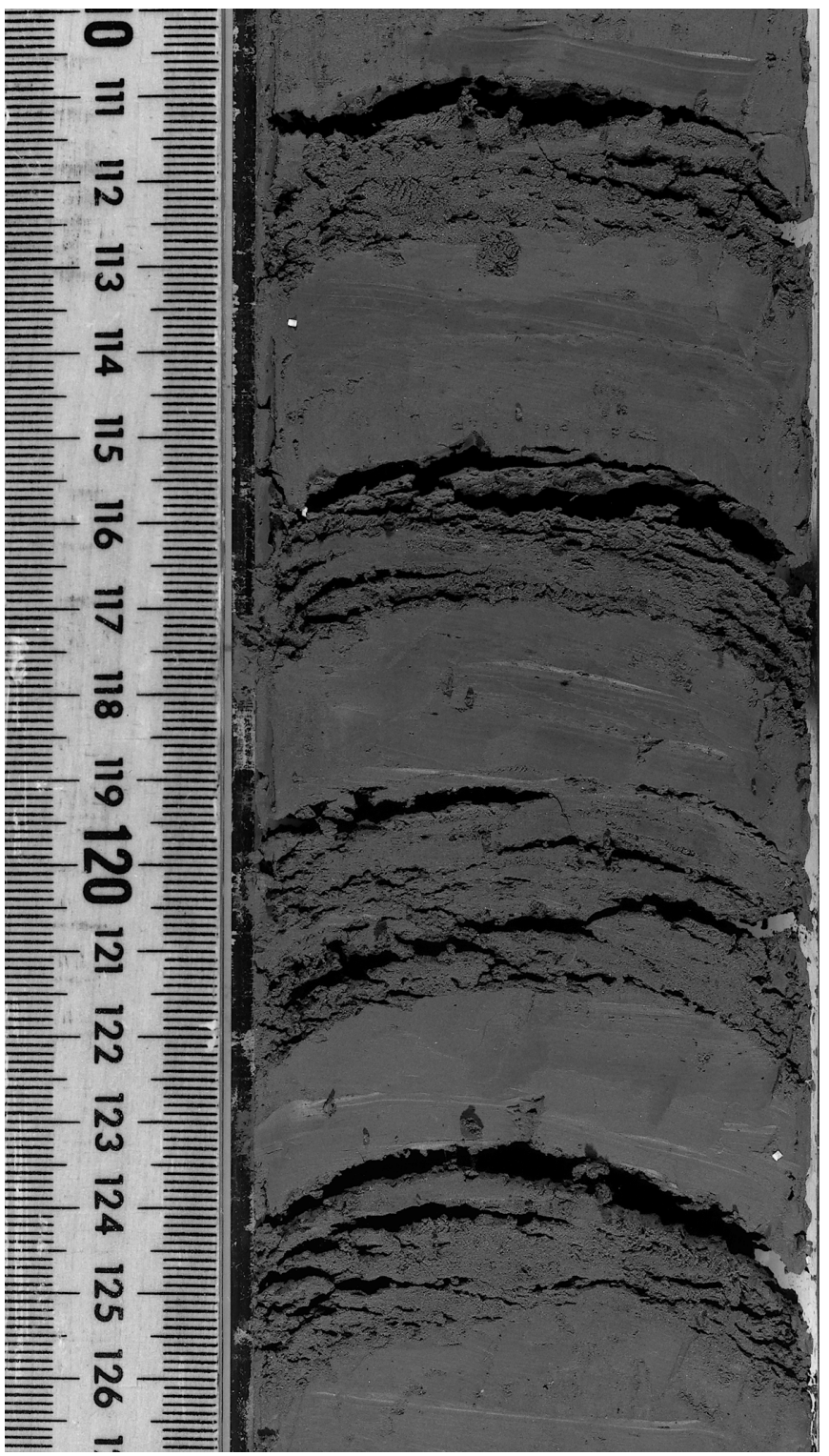

D

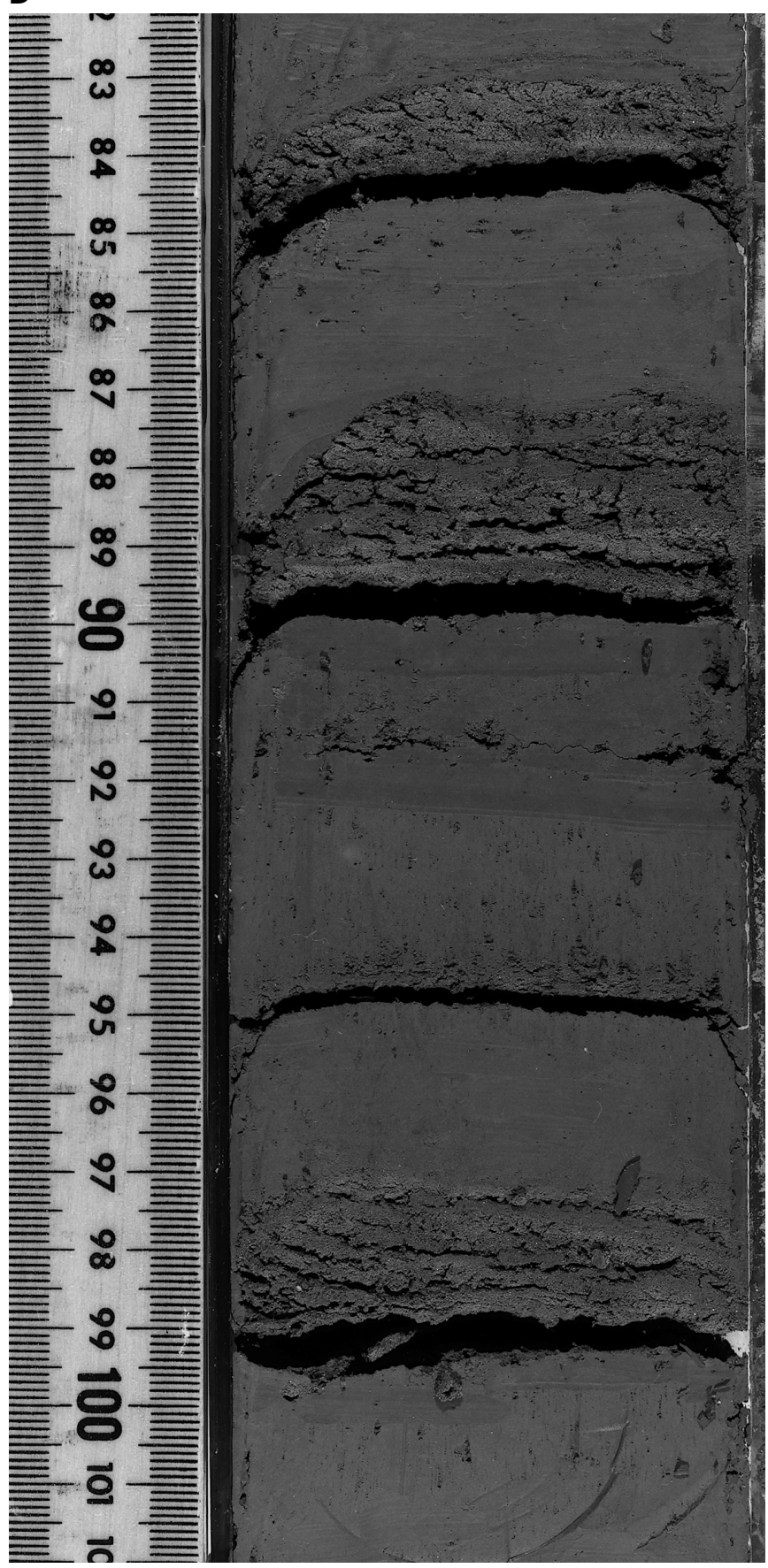

Figure 7 (continued). C. Gas-disrupted, thin structureless silt beds from distal levee deposits of the Amazon/Blue/Yellow Channel-levee Systems (interval 155930B-3H-1, 110-127 cm). D. Gas-disrupted, thin structureless silt beds from distal levee deposits of the Amazon/Brown/Aqua Channel-levee Systems (interval 155-930B-3H-7, 82-102 cm).

Dipping, discordant, and locally truncated color bands, laminae, beds, and contacts are ubiquitous throughout some intervals of Facies 12 (Figs. 16, 17). Dips range from very slight (e.g., Fig. 16B) to nearly $90^{\circ}$ (Fig. 17C) and dips of $50^{\circ}$ to $80^{\circ}$ are common (Figs. 16D, 17A, B). Groups of laminae and beds commonly dip at different attitudes and directions, indicating the occurrence of discordant stratal relationships (Figs. 16, 17). These relationships indicate that Facies 12 represents discrete, detached, commonly deformed blocks or clasts of variable size ranging from centimeters to at least several meters in scale.
Various scales of contorted beds and folds in some intervals of Facies 12 clearly indicate soft-sediment deformation (Fig. 16). Further evidence to suggest folding of the sediment, as well as faulting or shearing, is shown by the deformed nature of most of the color bands, laminae, and beds, which appear squeezed or stretched and show irregular boundaries that appear as crenulated patterns (Figs. 16B, 17). Many lithologic boundaries appear to show small-scale faults with displacements on the order of centimeters or less, which suggest brittle deformation associated with larger scale folding. Rare larger folds up to several meters in scale can be inferred from the attitudes of dip- 
A

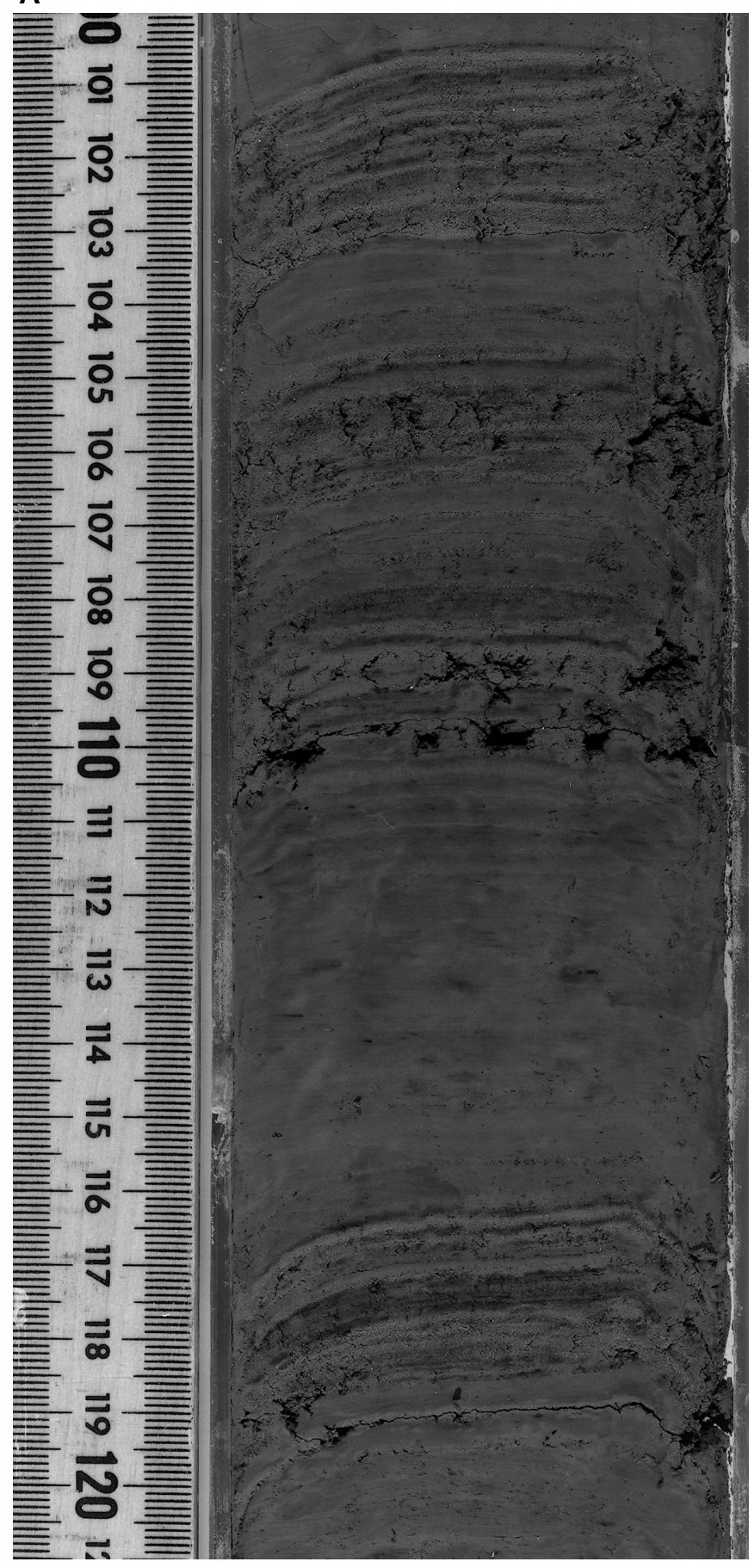

B

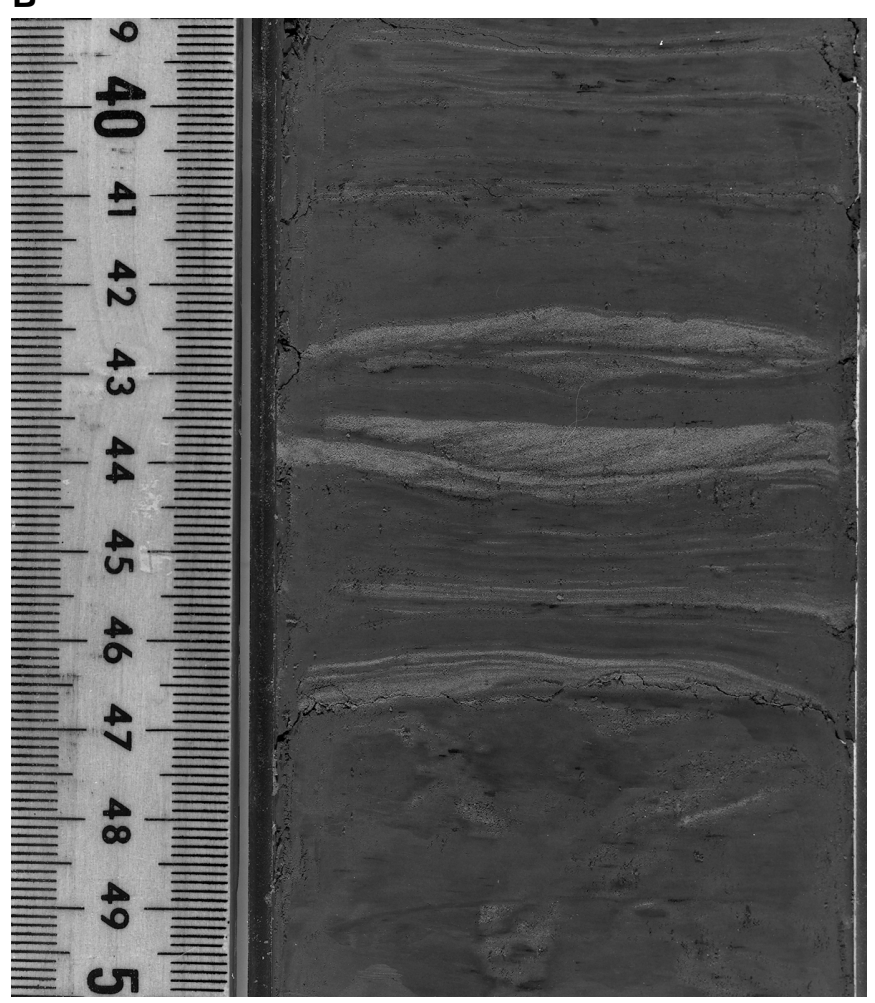

C

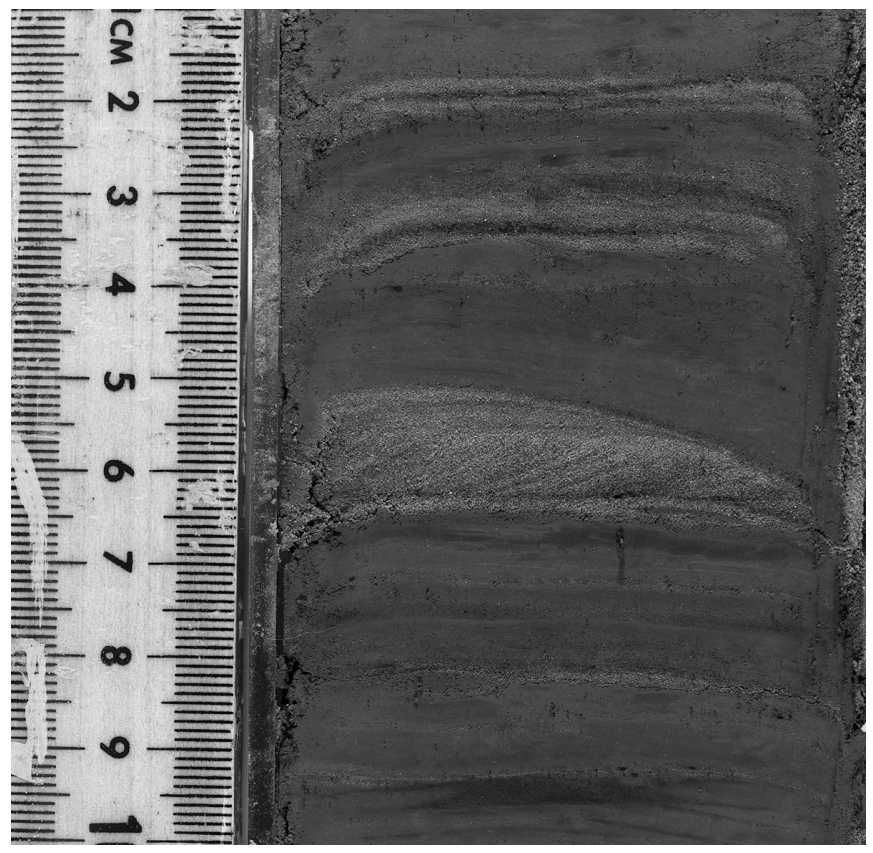

Figure 8. Examples of Facies 5 consist of laminated to thin-bedded organized silt, including parallel-laminated, cross-stratified, and normally graded beds. A. Thin-silt and fine-sand laminae couplets from levee deposits of the Aqua Channel-levee System (interval 155-935A-7H-1, 100-121 cm). B. Parallel- and crosslaminated silt laminae and thin beds from levee deposits of the Aqua/Brown Channel-levee System (interval 155-940A-15X-5, 39-50 cm). C. Parallel- to crosslaminated silt laminae and thin beds from the distal portion of the Purple Channel-levee System (interval 155-944A-21X-CC, 1-10 cm). 
D

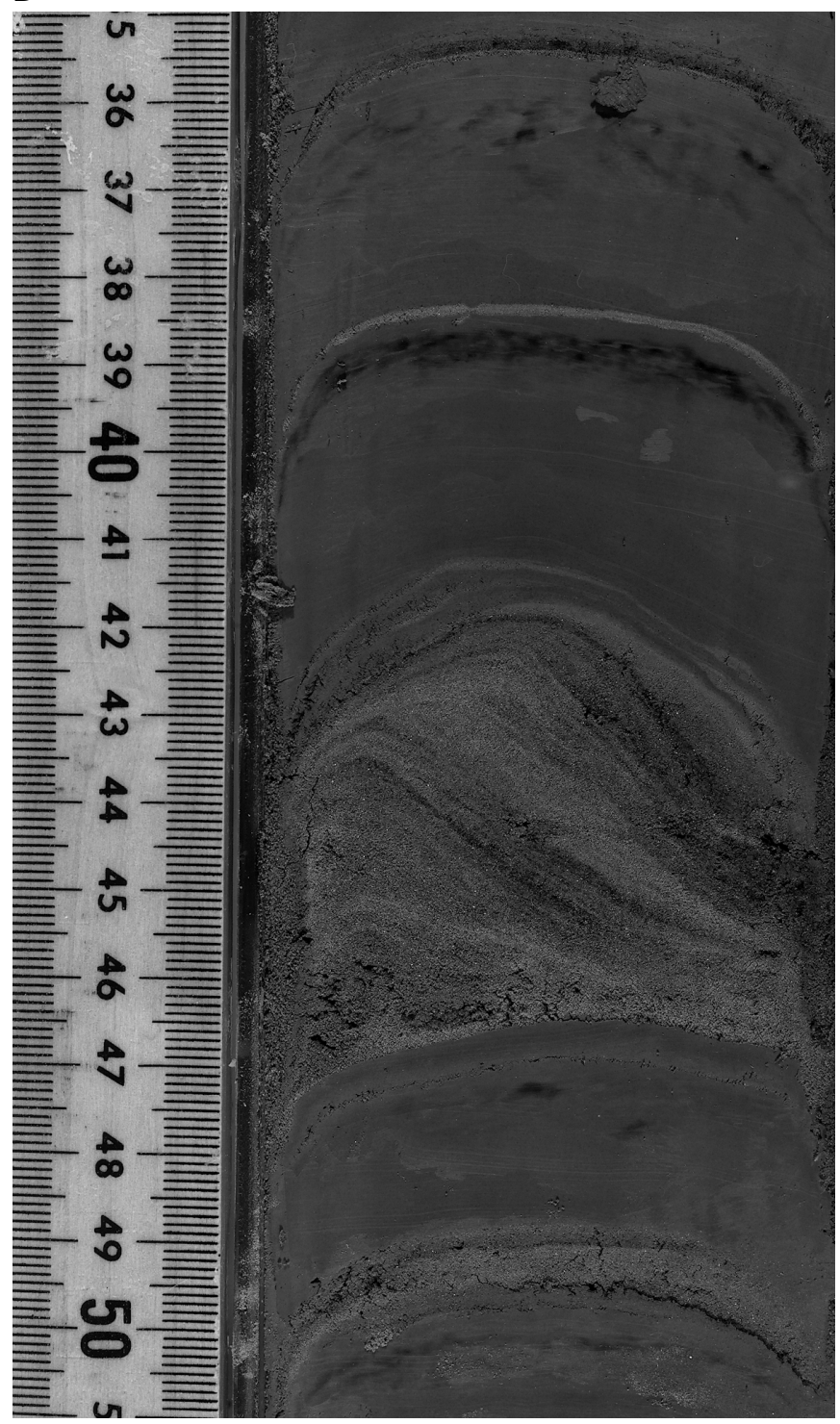

E

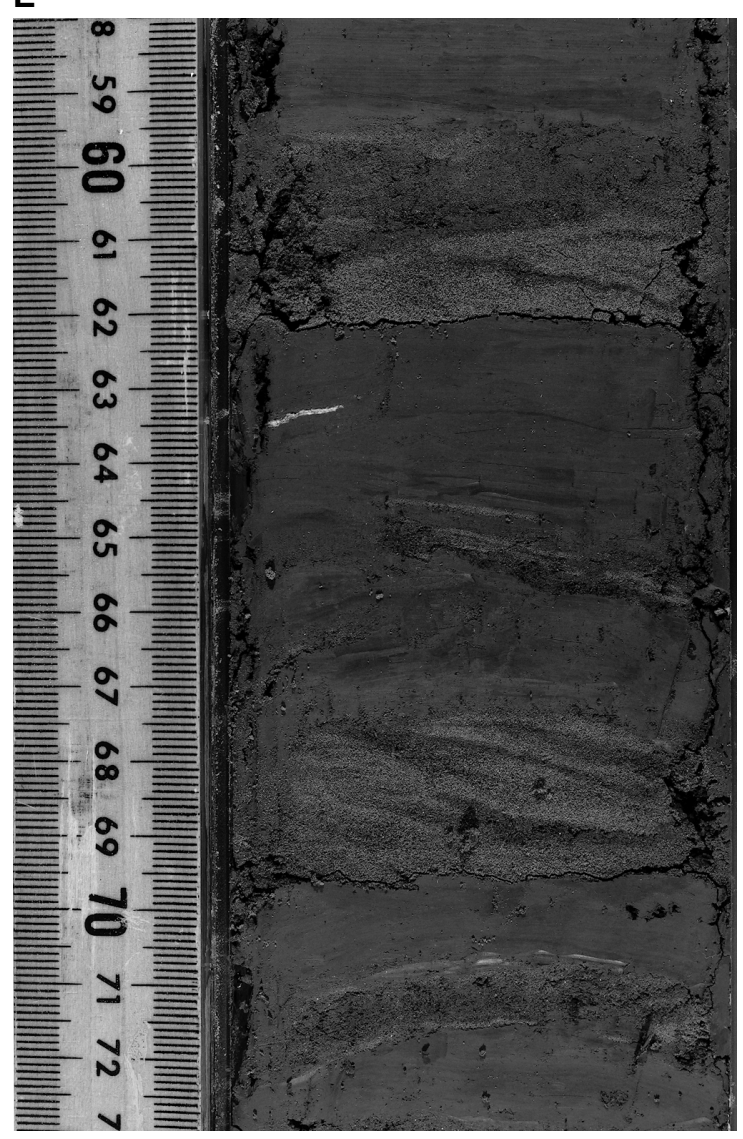

F

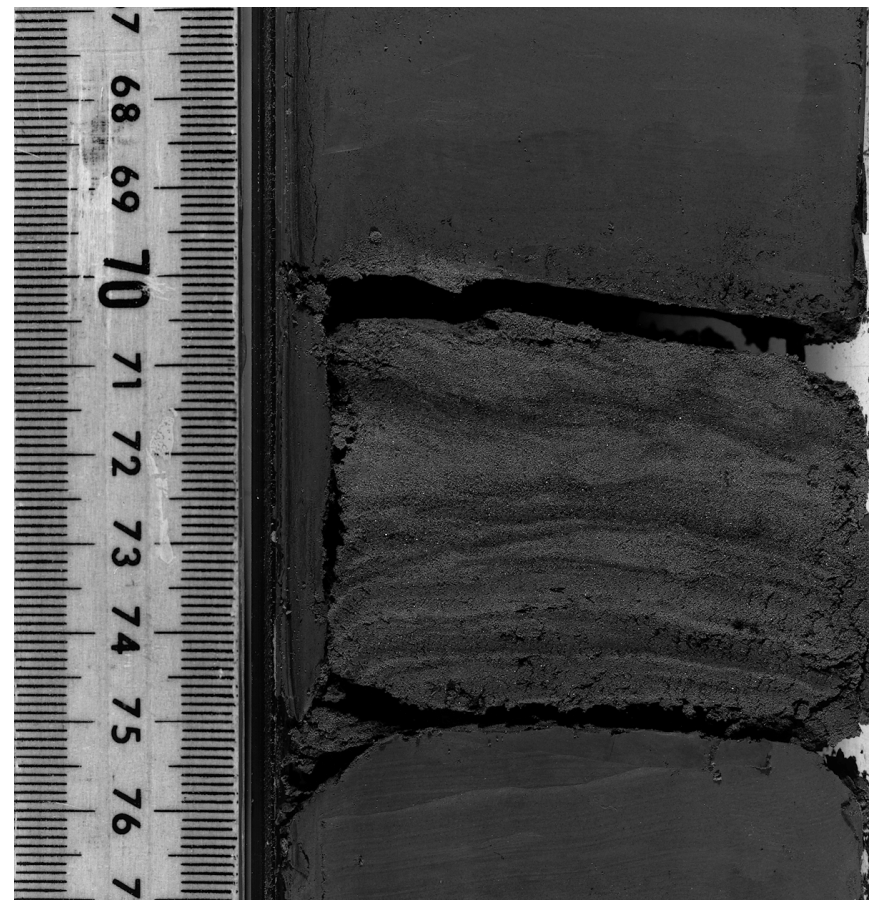

Figure 8 (continued). D. Wavy bedded, cross-laminated silt and silty sand bed $(41.5-47.5 \mathrm{~cm})$ from lower fan deposits. Note that the very fine silty sand passes gradationally upward through a division of alternating silt/mud laminae into overlying mud $\left(39-42 \mathrm{~cm}\right.$ ) and thus represents a $\mathrm{T}_{\text {cde }}$ turbidite (interval 155-946A$13 \mathrm{H}-4,35-51 \mathrm{~cm}$ ). E. Normally graded and cross-laminated silt beds and laminae from HARP units (interval 155-931B-25X-2, 58-73 cm). F. Silt bed displaying parallel- and cross-lamination (Bouma $\mathrm{T}_{\mathrm{b}-\mathrm{d}}$ ) from levee deposits of the flank of the Yellow Channel-levee System (interval 155-933A-6H-5, 67-77 cm). 
A

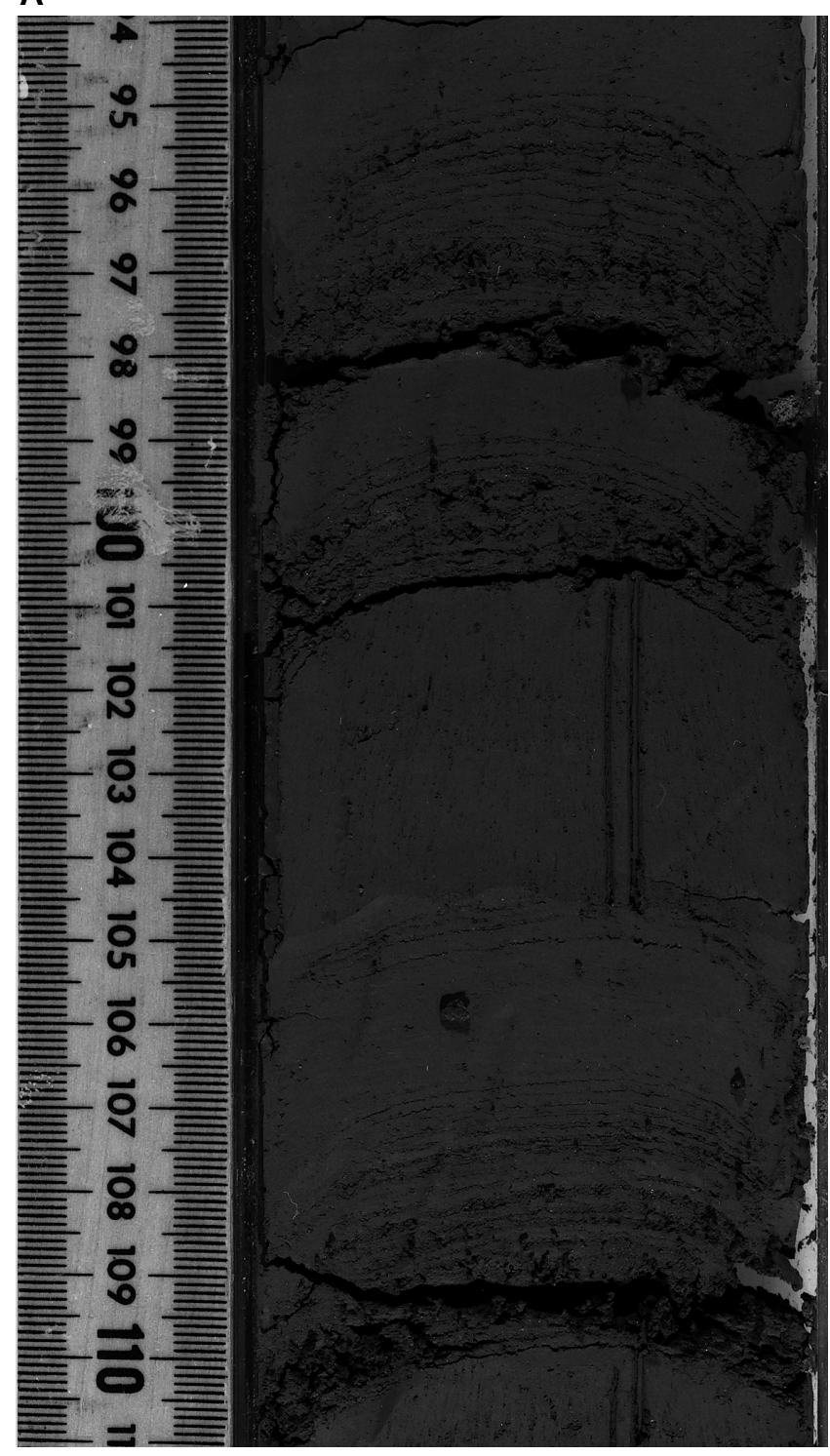

B

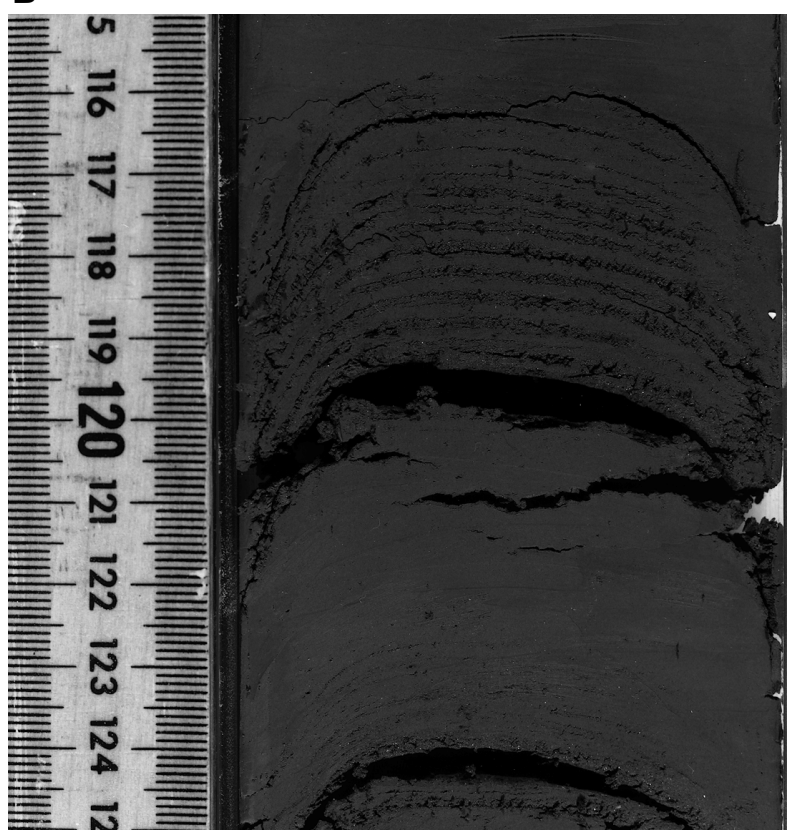

C

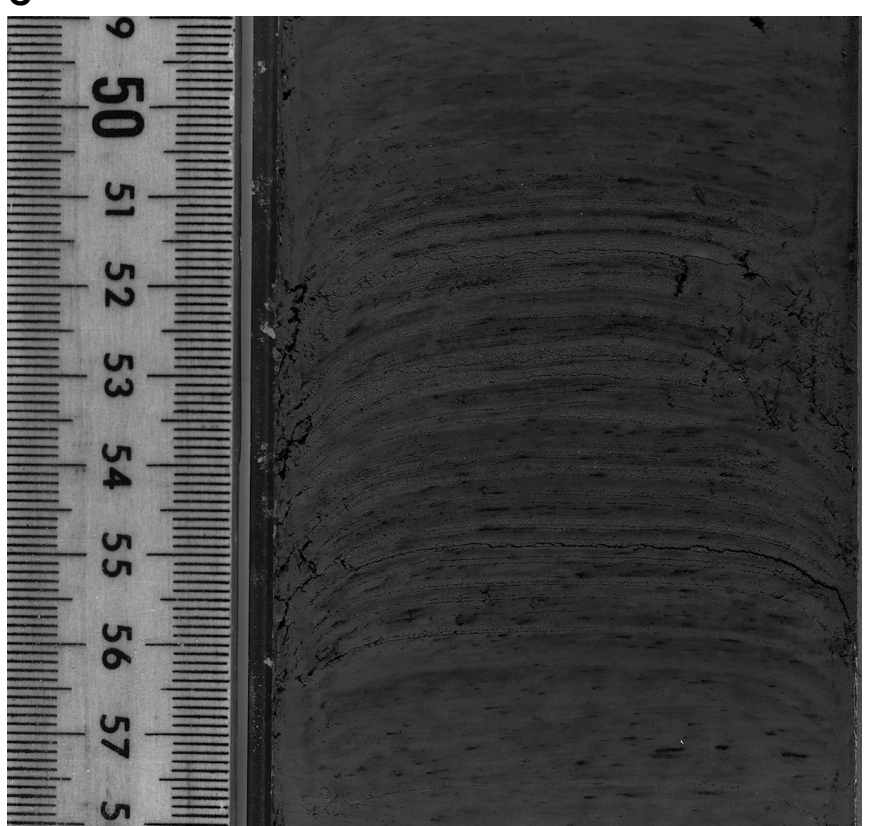

Figure 9. Examples of Facies 6 consists of very thin, regular silt and mud laminae. A. Numerous thin $(\sim 1 \mathrm{~mm})$ silt and mud laminae from levee deposits of Channel-levee System 5 (interval 155-931A-4H-3, 94-111 cm). B. Numerous thin ( 1 mm) silt and mud laminae from levee deposits of Channel-levee System 5 (interval 155-931B-4H-6, 115-125 cm). C. Numerous thin $(\sim 1 \mathrm{~mm})$ silt and mud laminae in distal levee deposits of the Amazon/Brown Channel-levee Systems (interval 155-944D-4H-5, 49-58 cm).

ping beds in some intervals. The scale of shearing, faulting, and folding of sediment comprising Facies 12 are evident in the FMS data (Piper et al., Chapter 6; Pirmez et al., both in this volume).

\section{Facies 13: Biogenic Mud}

Thin, bioturbated intervals of tan to brown to gray-brown to light gray mud with relatively high concentrations of foraminifers and calcareous nannofossils rarely occur within the Amazon Fan sediment and comprise Facies 13 . These sediments are mainly foraminifer-rich clay (10\%-30\% foraminifers) and foraminifer clays (30\%-60\% foraminifers; Shipboard Scientific Party, 1995c). Most notably, the upper few decimeters of sediment forming the modern seafloor is composed of brown to gray brown foraminifer-rich clay to foraminifer clay of Facies 13 (Fig. 18) throughout the Amazon Fan and the adjacent continental slope, rise, and abyssal plains of the Guiana Basin and is mainly Holocene in age (Damuth, 1977). This interval is present in all Leg 155 holes (Flood, Piper, Klaus, et al., 1995). Older 
intervals of similar calcareous-rich $(10 \%-30 \%$ calcareous microfossils; Shipboard Scientific Party, 1995c), biogenic sediment were rarely recovered deeper in the fan at some Leg 155 sites and apparently represent older interglacials of the late Pleistocene (see Mikkelsen et al.; Piper et al., Chapter 39; Maslin and Mikkelsen; Showers et al., all in this volume, for detailed discussions).

\section{Facies 14: Biogenic Sand}

Facies 14 consists of thin to thick beds of biogenic sand composed mainly of foraminifers. Pteropod and other aragonitic shell fragments may also be common constituents (Fig. 19). These biogenic sand beds commonly display normal grading. Although only one of these beds of biogenic sand was recovered in the Leg 155 cores (Fig. 19), others up to several meters thick have been recovered in piston cores from the continental slope and rise adjacent to the Amazon Fan (Damuth, 1973, 1977).

\section{Facies 15: Chemogenic Sediment}

Facies 15 consists of any sediment formed by diagenetic processes. Such intervals of chemogenic sediment are extremely rare in the Leg 155 cores and are generally only a few centimeters thick. The most notable, and regionally extensive, chemogenic sediment encountered is a distinctive, rust-brown-colored iron-rich crust, which is as much as a few centimeters thick and occurs in most holes at the base of the thin Holocene section of biogenic mud (Facies 13; Fig. 18). This diagenetic crust occurs throughout the Guiana Basin (and many other basins worldwide) and approximately marks the Holocene/Pleistocene boundary, although it is slightly diachronous ( 8$15 \mathrm{ka}$ ) across the Guiana Basin (Damuth and Fairbridge, 1970; McGeary and Damuth, 1973; Damuth, 1973, 1977; Richardson, 1974; Showers and Bevis, 1988). The geochemistry and formation of this diagenetic crust have been discussed by McGeary and Damuth (1973), and in considerable detail by Richardson (1974).

Other chemogenic sediment is rare in the Leg 155 cores. Diagenetic crystals of the mineral ikaite $\left(\mathrm{CaCO}_{3} \cdot 6 \mathrm{H}_{2} \mathrm{O}\right)$ were recovered near the top of Hole 941A (Fig. 20). As described above, sediment of some intervals is stained from black iron sulfide minerals, mainly hydrotroilite, a monosulfide of iron $\left(\mathrm{FeS} \cdot \mathrm{nH}_{2} \mathrm{O}\right)$, which is formed postdepositionally by heterotrophic bacteria acting on organic substances (Ericson et al., 1961; Flood, Piper, Klaus, et al., 1995; Shipboard Scientific Party, 1995c). Other iron sulfide minerals including greigite, mackinawite, marcasite, and diagenetic siderite are also present in some intervals (Flood, Piper, Klaus, et al., 1995; Burns, this volume).

\section{DISTRIBUTION OF SEDIMENTARY FACIES WITHIN THE AMAZON FAN}

\section{Background}

Prior to Leg 155 drilling, the distribution of sedimentary facies within the fan was inferred from the seismic facies $(3.5-\mathrm{kHz}$ and $\sim 100-\mathrm{Hz}$ seismic-reflection profiles), GLORIA side-scan sonar records, and short $(<10 \mathrm{~m})$, widely spaced piston cores. The seismicreflection data showed that the basic depositional unit of the fan was the aggradational channel-levee system (e.g., Fig. 21; Damuth and Kumar, 1975; Damuth and Embley, 1981). On the upper to middle fan, groups of these channel-levee systems on the fan surface were observed to overlap one another to form discrete channel-levee complexes (Damuth et al., 1983; Damuth et al., 1988); and older levee complexes were observed to be buried within the fan and separated by thick, regionally extensive mass-transport deposits (MTDs; Manley and Flood, 1988; Flood et al., 1991). In contrast, the lower fan was observed to be devoid of large channel-levee systems (although small, generally unleveed channels occur), and the high acoustic re- flectivity of the sediments suggested depositional lobes of coarse sediment (Damuth and Kumar, 1975; Damuth et al., 1988).

On seismic-reflection profiles, an individual channel-levee system displayed several acoustic elements or seismic facies that were suggestive of turbidite depositional processes, sediment distribution, and growth pattern. The channel was perched on a thick, acoustically transparent wedge-shaped levee system that appeared to be constructed of overbank deposits from turbidity currents. High-amplitude reflections (termed HARs) observed beneath the channel axis were interpreted as reflections from coarse-grained channel-fill deposits that accumulated in the channel floor and were buried as the channel-levee system aggraded (Damuth et al., 1983, 1988). In addition, more laterally extensive groups of HARPs were commonly observed to form the bases of channel-levee systems. HARPs were interpreted to consist of coarse sediment that was deposited either from flows spreading laterally from a channel mouth to form a lobe deposit or from flows moving through a crevasse during an avulsion event (i.e., crevasse splays) (Manley and Flood, 1988; Flood et al., 1991). In either case, the channel-levee system eventually prograded over the HARPs.

Piston cores from the Amazon Fan tended to support these interpretations and showed that the levees comprise mainly mud with thin silt and sand beds typical of overbank deposits, whereas the channels contained somewhat coarser, thicker silt and sand beds. Recovery of sand and gravel from HARs beneath the axis of the youngest channel of the Mississippi Fan during DSDP Leg 96 (Bouma et al., 1986) lent credence to interpreting HARs as coarse channel fill. Piston cores from the lower Amazon Fan contained the coarsest, thickest beds of sand, and cores from surficial debris flows showed disturbed, contorted sediment suggestive of mass-transport deposition. Piston cores also showed that the entire fan has been inactive since the beginning of the Holocene, because glacio-eustatic sea-level rise trapped Amazon River sediment on the inner continental shelf (Damuth and $\mathrm{Ku}-$ mar, 1975; Damuth and Embley, 1981; Damuth et al., 1988; Flood et al., 1991).

Leg 155 recovered long continuous cores through all of these acoustic and seismic units and subunits of the Amazon Fan (Flood, Piper, Klaus, et al., 1995). For the first time, we can observe the actual sedimentary facies successions that comprise these various acoustic units (e.g., HARs and HARPs) and depositional elements (e.g., channels, levees, and MTDs). Figure 21 is a schematic crosssection of a typical channel-levee system underlain by a regional MTD and shows where each of the 15 lithofacies described above occur within a channel-levee system.

\section{Levee Systems-Overbank Deposits}

The overbank deposits, which form the major part of most passive-margin channel-levee systems, are constructed of seven interbedded facies (Fig. 21). Color-banded mud and clay (Facies 9) is the most common facies comprising these deposits (Fig. 13). Interbeds of coarser sediment are rare to extremely abundant and are mainly composed of silt-size particles, occurring in laminae and thin beds. Beds of medium thickness are rare to common (Fig. 5F), and thick beds are very rare. The most abundant granular facies is organized silt laminae and thin beds (Facies 5), which is usually present as parallel- and cross-laminated laminae and thin beds (Fig. 8A-D, F), rarely with normal grading or with climbing ripples. Less common overall, but abundant in some intervals, are disorganized or structureless silt laminae and beds (Facies 4; Fig. 7), color-banded silt and mud (Facies 8; Fig. 11A, B, D), and irregular or discontinuous silt laminae (Facies 7; Fig. 10). Very thin, regular silt and mud laminae (Facies 6; Fig. 9) are rare. Organized beds and laminae of fine sand, which commonly show normal grading, parallel- and/or cross-lamination locally (Facies 3) are rare to common in some levee intervals (Fig. 6). In some overbank deposits, the coarse laminae and beds (Facies 3 to 8 ) show 
$\mathbf{A}$

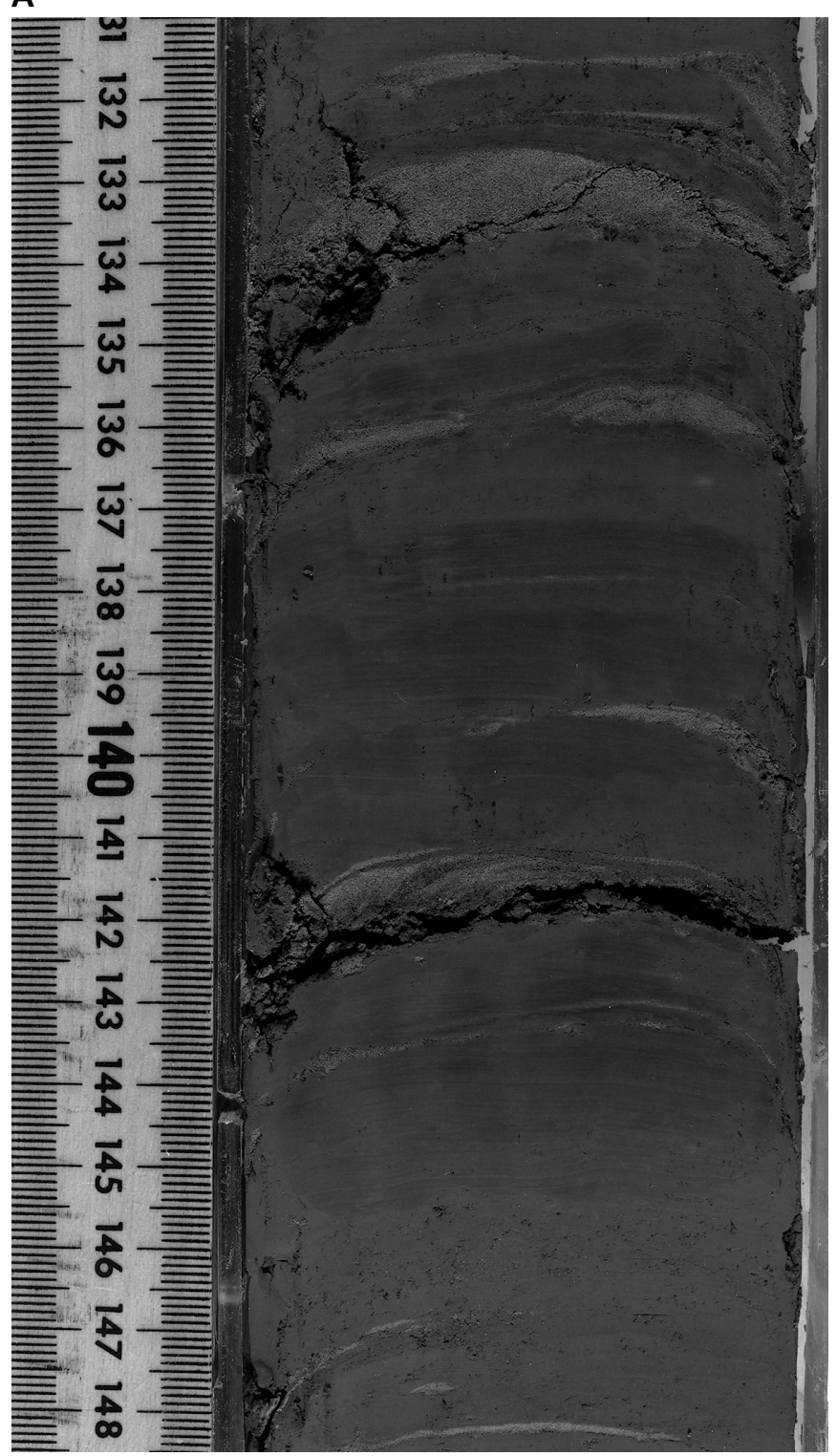

B

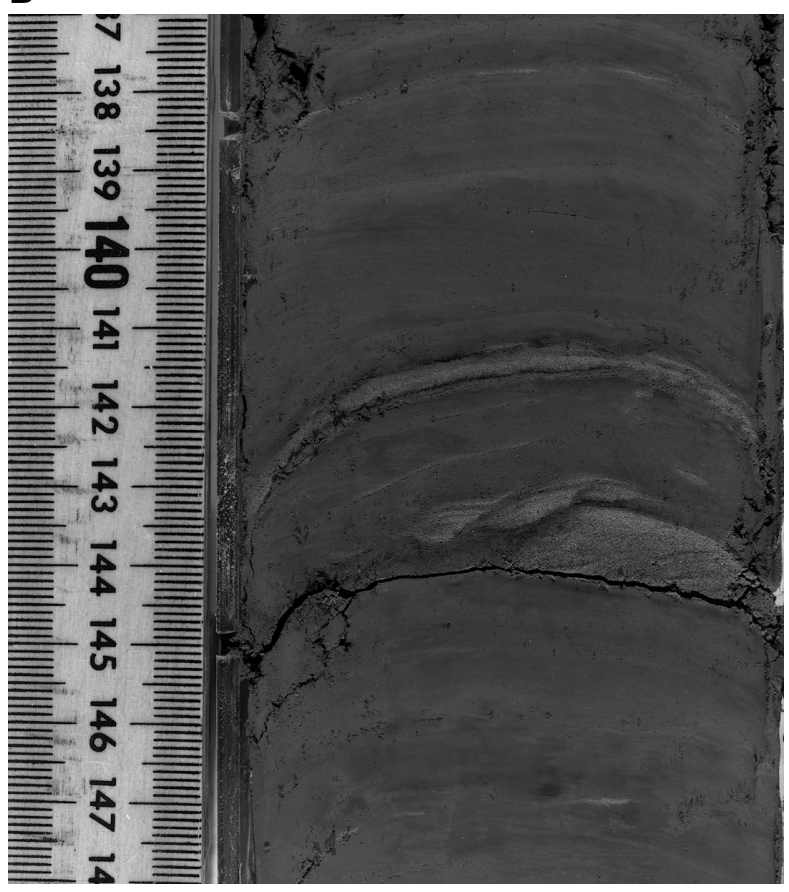

Figure 10. Examples of Facies 7 consist of irregular or discontinuous silt laminae. A. Thin and discontinuous silt laminae and thin beds from levee deposits of the Aqua Channel-levee System (interval 155-935A-8H-4, 131-148.5 cm). B. Thin and discontinuous silt laminae and thin beds from levee deposits of the Aqua Channel-levee System (interval 155-935A-8H-6, 137-148 cm).

cycles of thickening- or thinning-upward trends (see site chapters in Flood, Piper, Klaus, et al., 1995; Shipboard Scientific Party, 1995a, plate $1 ; 1995 \mathrm{~b}$, plate 2 ). The bed thicknesses, particle-size range, and bedding structures of these facies clearly are consistent with overbank deposition on levees by turbidity currents and related gravitycontrolled flows moving down the fan channels.

\section{HAR Units and Channel-Fill Deposits}

Cores from the axis of the modern Amazon Channel and the underlying HAR units contain much more abundant thicker bedded, coarse facies than do the levee deposits (Fig. 21). The most prevalent facies is thick-bedded, disorganized structureless to chaotic sand (Facies 2; Figs. 3, 4). These beds commonly contain abundant large mud clasts and consist of poorly sorted fine to coarse sand (Fig. 4A, C, E, F). The mud clasts can help prevent the loss of sand during coring and, thus, enhance the recovery of this facies. Beds range up to several meters in thickness. Medium- to thick-bedded organized sands
(Facies 3) are also common to abundant in the HARs and channel fills (Fig. 5B). Normal grading is the most predominant structure and many graded sand beds grade upward through silt to clay at the top. Beds of Facies 3 are commonly composed of fine to medium sand and are predominantly of medium thickness (Fig. 5B). The bed thicknesses, particle-size range, and bedding structures of Facies 2 and 3 clearly are consistent with transport and deposition in fan channels by turbidity currents and related gravity-controlled flows moving down the channels. Intervals of deformed to chaotic mud or sand with contorted beds, folds, large clasts, etc. (Facies 12 and 2; Fig. 4G) also occur in HARs and channel-fills and appear to be the result of localized sediment failure and mass-transport laterally and downfan of overbank (levee) deposits (Fig. 21).

\section{HARP Units and Lower Fan Depositional Lobes}

The coarsest and thickest sand beds appear to occur in the broad thick HARP units at the bases of leveed-channel overbank deposits 
C

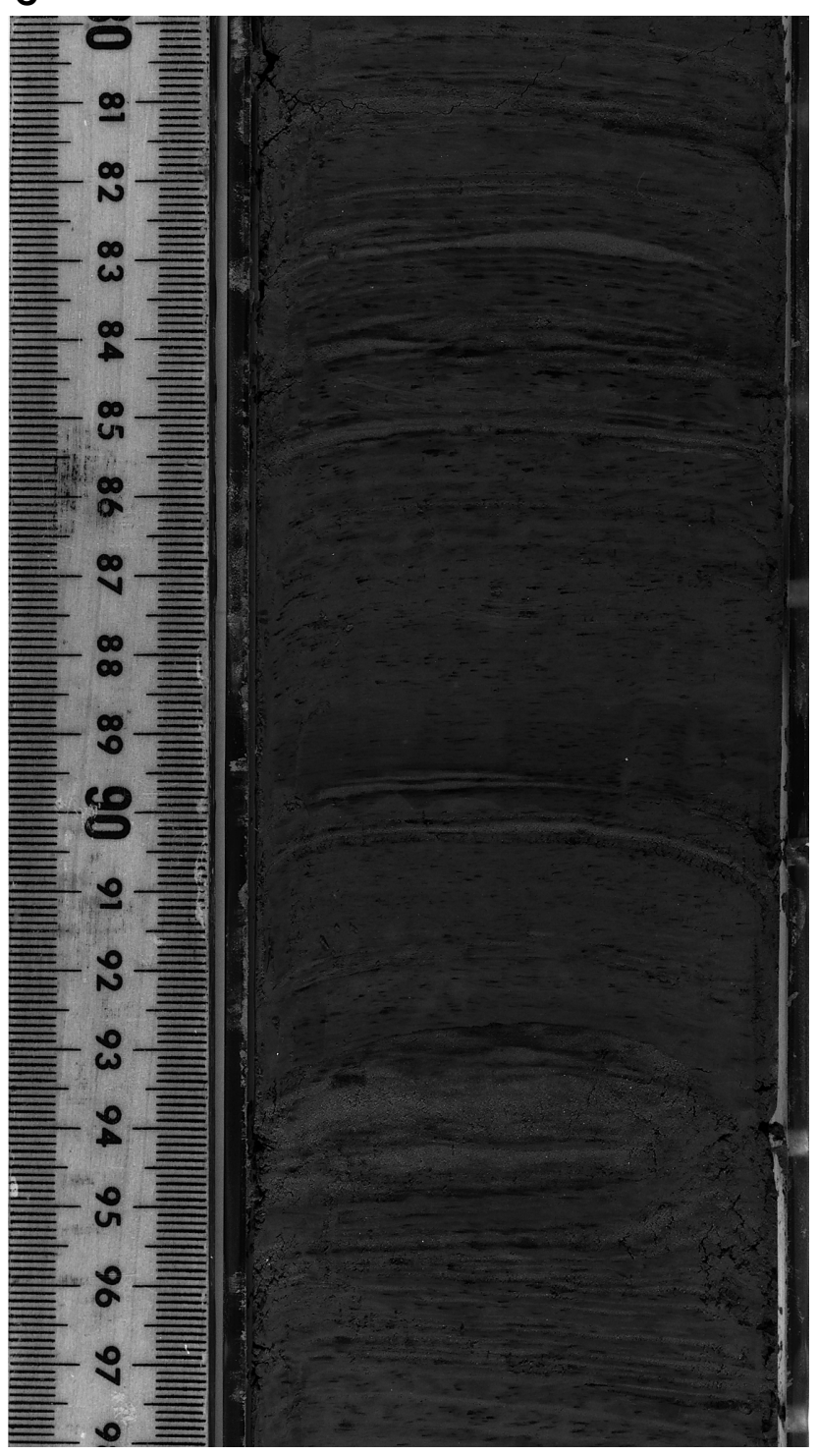

D

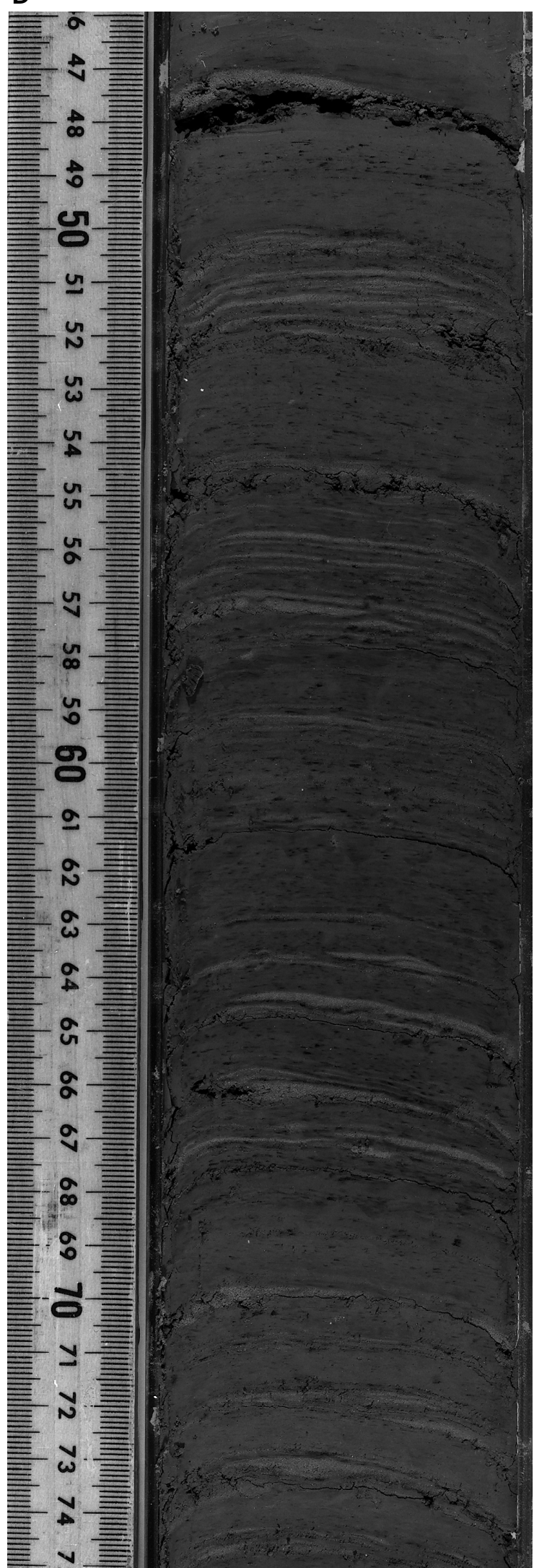

Figure 10 (continued). C. Thin and discontinuous silt and mud laminae from levee deposits of the Amazon Channel-levee System (interval 155-940A-6H-4, $80-98 \mathrm{~cm}$ ). D. Thin and discontinuous silt and mud laminae from levee deposits of the Amazon Channel-levee System (interval 155-940A-6H-6, 46-75 cm). 
A

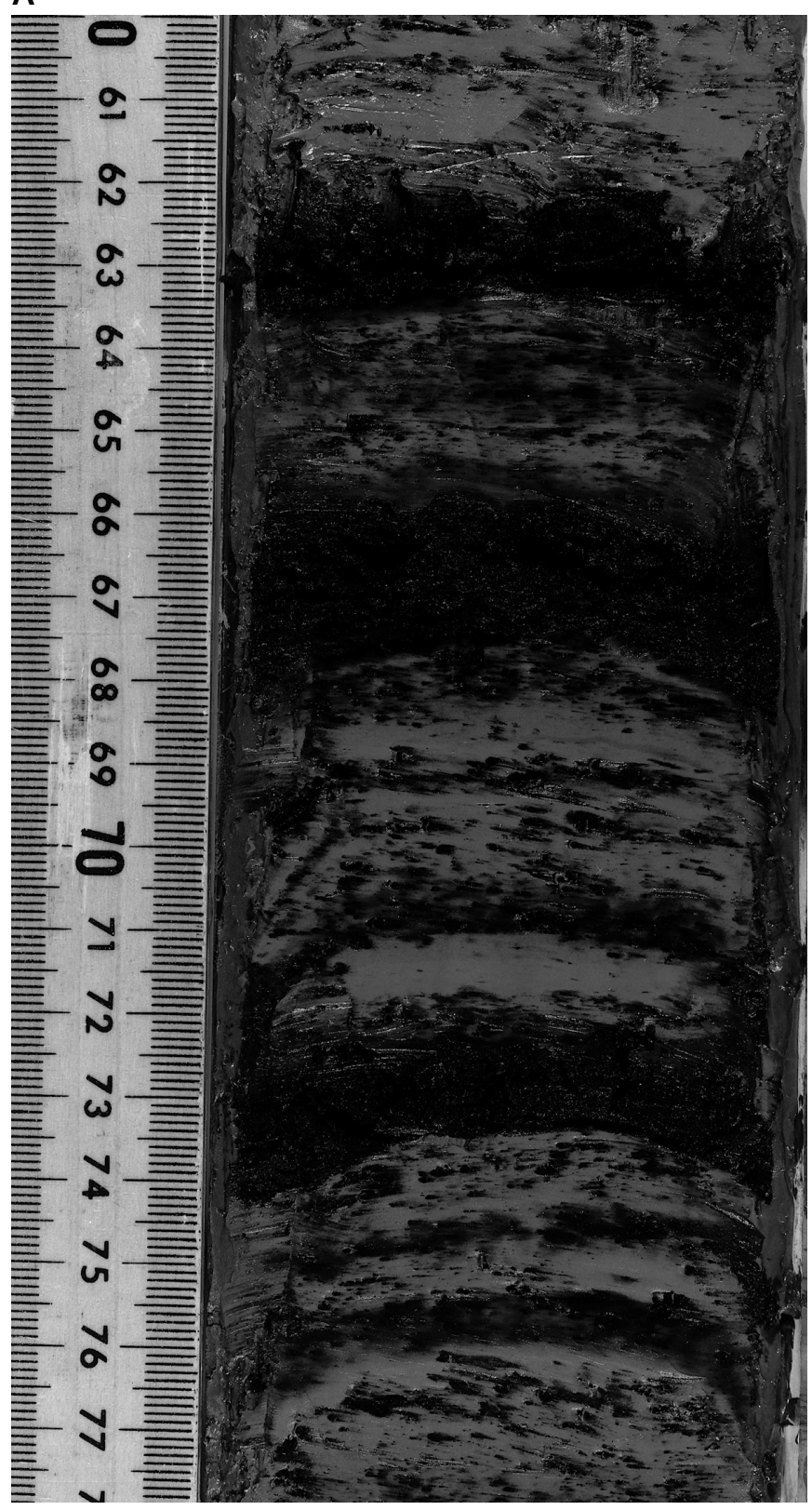

B

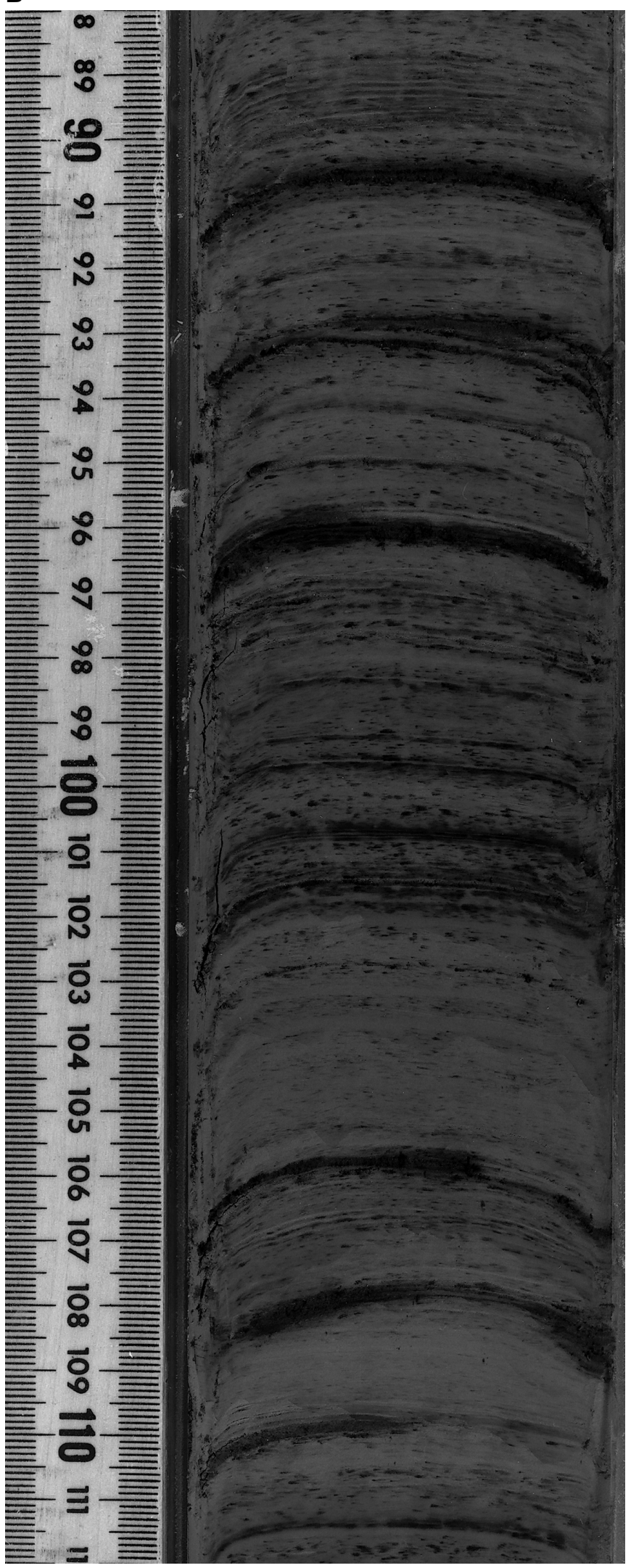

Figure 11. Examples of Facies 8 consist of color-banded and/or color-mottled silt and mud laminae and thin beds. A. Color-banded, mottled mud, silty mud laminae and thin beds in distal levee deposits of the Amazon/Aqua Channel-levee System (interval 155-930D-1H-3, 60-78 cm). B. Color-banded silt laminae in levee deposits of the Amazon Channel-levee System (interval 155-940A-3H-4, 88-112 cm). 
C

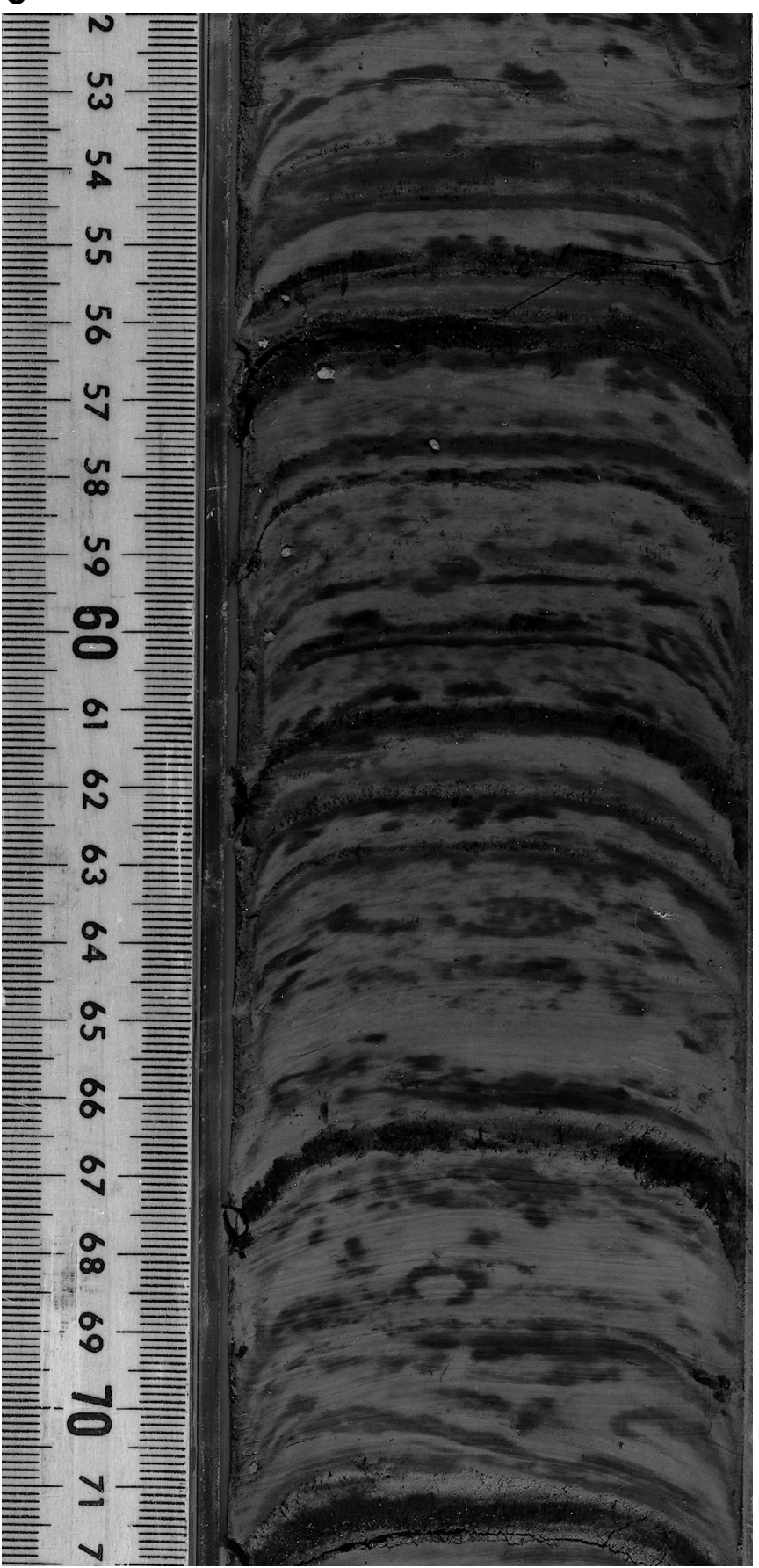

Figure 11 (continued). C. Color-banded and mottled clay and silt laminae and thin beds in a large displaced mud clast in channel-fill deposits of the Amazon Channel on the lower fan (interval 155-945A-1H-6, 52-72 cm).

(Fig. 21) and in lower fan deposits that presumably represent coalescing depositional lobes deposited beyond the mouths of leveed channels. Some intervals of little to no core recovery appear to contain thick beds of disorganized gravel or sandy gravel (Facies 1; Fig. 2), but the abundance of this facies remains uncertain (see Pirmez et al., this volume). More commonly, HARPs and lower fan deposits contain medium to thick (up to $12 \mathrm{~m}$; see Pirmez et al., this volume) beds of disorganized structureless to chaotic sand (Facies 2). Poorly sorted medium to coarse sand with large mud clasts is common (Fig. 4D).

\section{D}

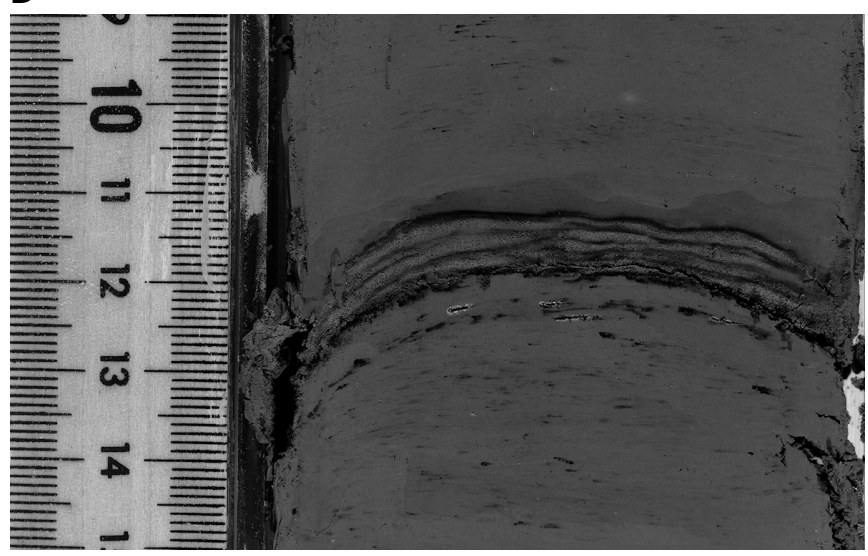

Figure 11 (continued). D. Color-banded, sharp-based silt lamina with wavy lamination denoted by black hydrotroilite staining. Levee deposits near the levee crest of Amazon Channel-levee System (interval 155-939A-4H-7, 9$15 \mathrm{~cm})$.

Medium to thick organized sand beds (Facies 3) consisting of mainly fine to medium sand are also common in these units (Fig. 5A). Thin, organized silt beds (Facies 5; Fig. 8E) also very rarely occur. In addition, some HARP units contain at least thin intervals of disorganized pebbly or gravelly mud (Facies 11; Fig. 14A, D), which is normally indicative of debris flow. These facies appear consistent with the interpretation that HARP units are formed by deposition of coarse sediment issuing from the mouths of fan channels as channel-levee systems prograde downfan, or as crevasse splays developed in response to avulsion events along channels (e.g., Flood et al., 1991; fig. 23.15). Similarly, the deposits of the lower fan consist of coarse sediment of Facies 1 through 3 (Figs. 3D, 4B, 5C-E) that were transported through the fan channels by turbidity currents and related gravitycontrolled flows before being deposited radially from the channel mouths across the lower fan (e.g., Damuth et al., 1988).

\section{Mass-Transport Deposits (MTDs)}

Cores from the thick, regionally extensive MTDs on the fan surface (Western [WMTD] and Eastern [EMTD]; Damuth and Embley, 1981), and buried within the fan (e.g., Unit R and Bottom MTDs; Manley and Flood, 1988; Flood et al., 1991; Piper et al., Chapter 6, this volume) contain facies that clearly demonstrate their origin by large-scale sediment failure and mass-transport downfan (Figs. 1, 21). These deposits consist predominantly of thick intervals (tens of meters) of deformed or chaotic mud with mud clasts and blocks, or discordant, contorted, folded, faulted, or truncated beds (Facies 12; Figs. 15B-D, 17). Thick intervals of disorganized pebbly or gravelly mud and sandy mud (Facies 11; Fig. 14B, C) are commonly interbedded with Facies 12. Intervals of homogeneous, structureless mud (Facies 10) are also sometimes interbedded with Facies 11 and 12, and may represent large undeformed displaced blocks.

In addition to these regionally extensive MTDs, thin, localized MTDs occur both on the backsides of levees as a result of local sediment failure and in channel-fill deposits, where presumably channel walls have slumped towards the channel floor (Fig. 21). MTDs from the backsides of levees consist of deformed or chaotic mud with contorted, folded, and discordant, truncated beds (Facies 12; Fig. 16BD). MTDs in channel fills or HAR units consist predominantly of deformed or chaotic mud with abundant deformed mud clasts and contorted, folded, truncated beds (Facies 12; Figs. 15A, 16A) and disorganized sand with deformation (contorted, folded, etc.; Fig. 4G) and mud clasts (Facies 2). 


\section{Pelagic/Hemipelagic Drape Deposits Overlying Inactive Channel-Levee Systems}

Inactive channel-levee systems, channel-levee complexes, and lower fan areas away from the active channel-levee system of the fan generally receive relatively little sediment compared with the active areas of the fan. Sedimentation is by pelagic rain of biogenic material from surface waters and hemipelagic deposition of terrigeneous clays that move downslope from the shelf through the water column, or drift laterally outward from overbank spill along the active fan channel and are probably assisted by currents within the water masses of the benthic boundary layer or lower part of the water column. These pelagic and hemipelagic processes deposit a relatively thin (decimeters to meters thick) drape of sediment over the inactive parts of the fan (Fig. 21) and consist of color-mottled mud and clay, which is usually gray (Facies 9; Fig. 12), and biogenic mud, which is light gray to brown gray (Facies 13; Fig. 18). These sediments are generally wellbioturbated.

Glacio-eustatic sea-level rise associated with Quaternary interglacial phases can cause the entire Amazon Fan to become temporarily inactive. For example, rapid sea-level rise at the beginning of the Holocene forced the locus of Amazon River sedimentation landward to the inner continental shelf, thereby cutting off the large terrigeneous sediment influx to the fan. As a result, active fan growth has been temporarily halted throughout the Holocene, and only a thin $(<1 \mathrm{~m})$ layer of biogenic mud (Facies 13; Fig. 18) has slowly accumulated ( $\sim 0.03$ to $0.15 \mathrm{~m} / \mathrm{k} . \mathrm{y}$.) across the fan (Damuth and Fairbridge, 1970; Damuth and Kumar, 1975; Damuth, 1977; Damuth et al., 1988; Flood, Piper, Klaus, et al., 1995). A distinctive, regionally extensive layer of chemogenic sediment (Facies 15) consisting of a thin $(<10$ $\mathrm{cm}$ ), rust-colored iron-rich crust of diagenetic origin (e.g., Damuth, 1977) occurs at the base of this biogenic mud unit (Fig. 18; see Facies 15) and marks approximately the Holocene/Pleistocene boundary, as well as the transition from gray color-mottled muds of Facies 9 below (i.e., active fan sedimentation) to brown calcareous-rich sediments of Facies 13 above (i.e., inactive fan).

Older intervals of similar calcareous-rich biogenic mud were recovered deeper in the fan at some Leg 155 sites and apparently attest to similar periods of fan inactivity during older interglacial highstands of the late Pleistocene (Flood, Piper, Klaus, et al., 1995; see also Mikkelsen et al.; Piper et al., Chapter 39; Maslin and Mikkelsen; Showers et al., all in this volume). These Holocene and older intervals of biogenic mud can be condensed sections equivalent to the transgressive systems tracts (TST), maximum flooding surfaces (MSF), and beginning of the highstand systems tracts (HST) in the sequence-stratigraphic conceptual model of Vail and co-workers (e.g., Vail et al., 1991).

\section{Bioclastic Turbidite Deposits}

Facies 14 (biogenic sand), which was recovered only at Site 941, has previously been recovered in piston cores on the continental slope and rise adjacent to the Amazon Fan (Damuth, 1973). Evidence for deposition of these biogenic sand beds by turbidity currents or related gravity-controlled flows includes (1) normal grading; (2) the presence of aragonitic shells (e.g., pteropods) beneath the aragonite compensation depth; (3) sharp bases and gradational tops; and (4) the presence of well-sorted, sand-sized foraminifers and absence of siltand clay-size particles (including juvenile foraminifers). Such beds can be derived from failure of pelagic sediment on the continental shelf or slope, small basement knolls that rise up to a few hundred meters above the lower fan, and the western flank of the Ceara Rise (see Damuth and Kumar, 1975; figs. 2, 3). Such topographic highs are covered with pelagic sediment that sporadically fails and then is transported downslope onto the fan by slumps, debris flows, and turbidity currents (see, for example, the small debris-flow deposit in Damuth and Flood, 1985; fig. 4C). Thin intervals of Facies 14 therefore should be expected to occur only rarely within the fan.
A

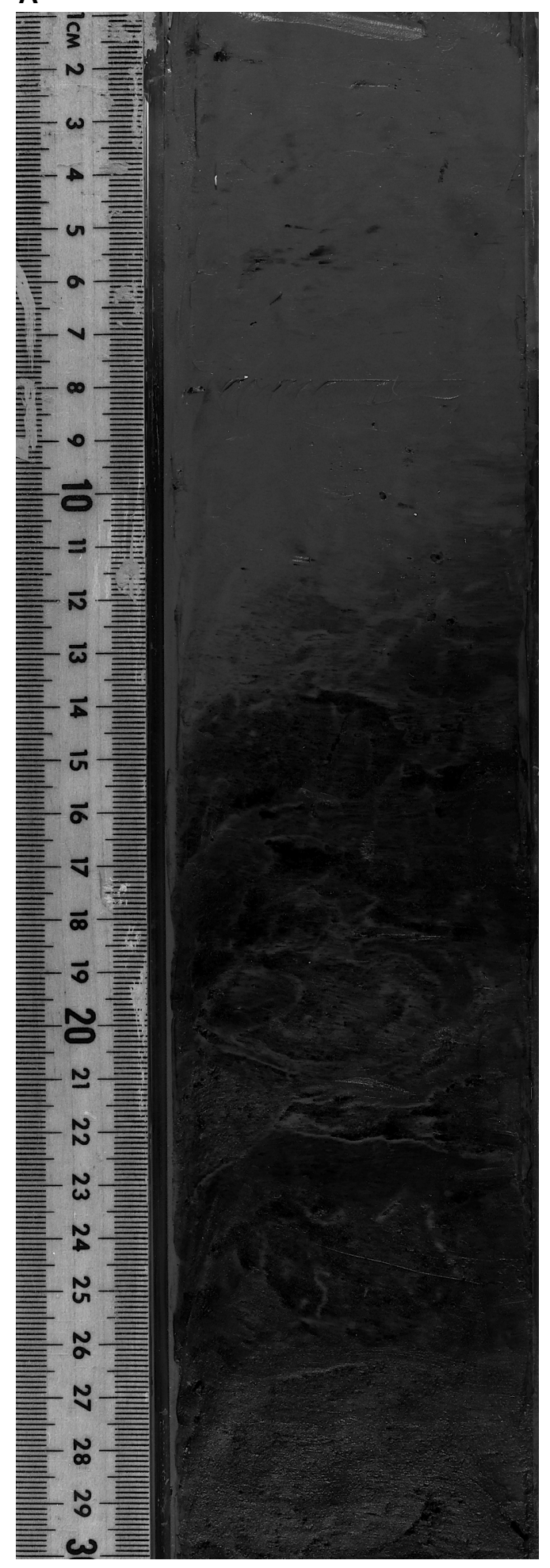

Figure 12. Examples of Facies 9 consist of color-mottled clay and mud. A. Color mottling by intensive hydrotroilite staining (below $13 \mathrm{~cm}$ ) in dark gray bioturbated mud overlying the WMTD (interval 155-941B-1H-4, 1-30 cm). 


\section{B}

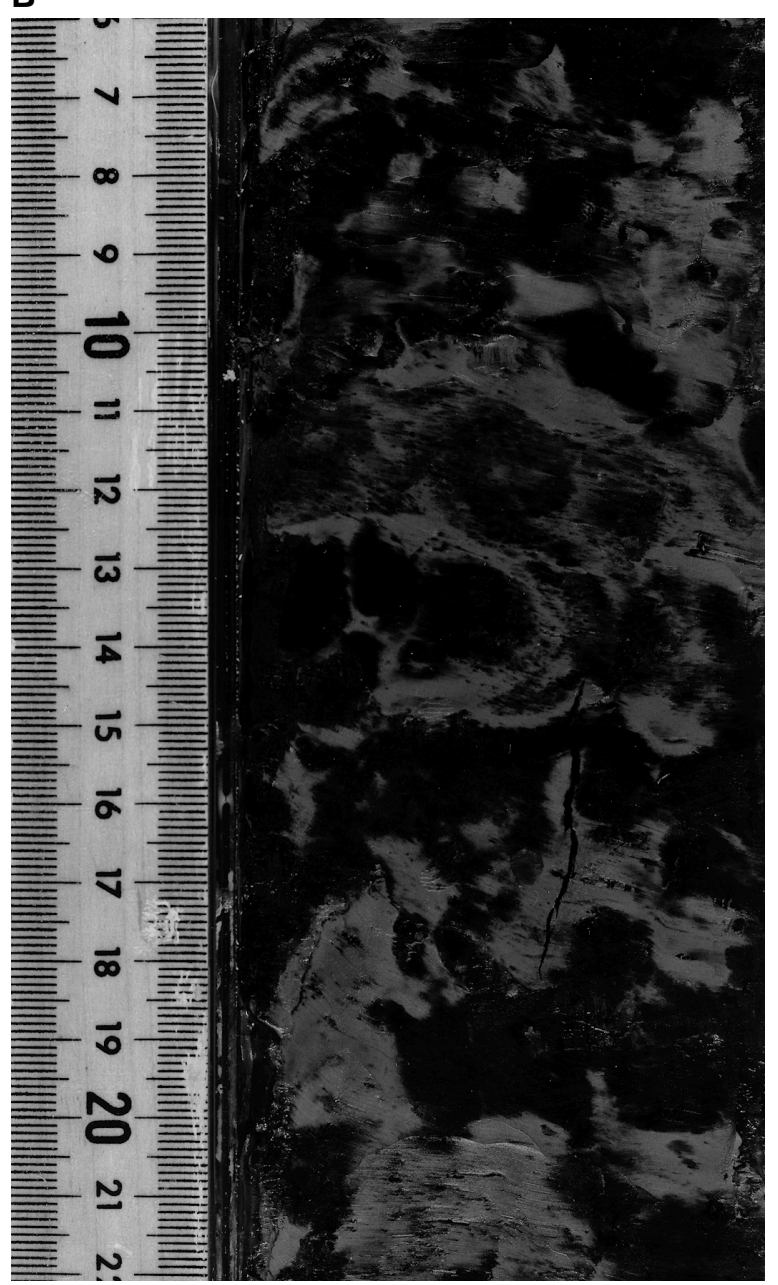

C

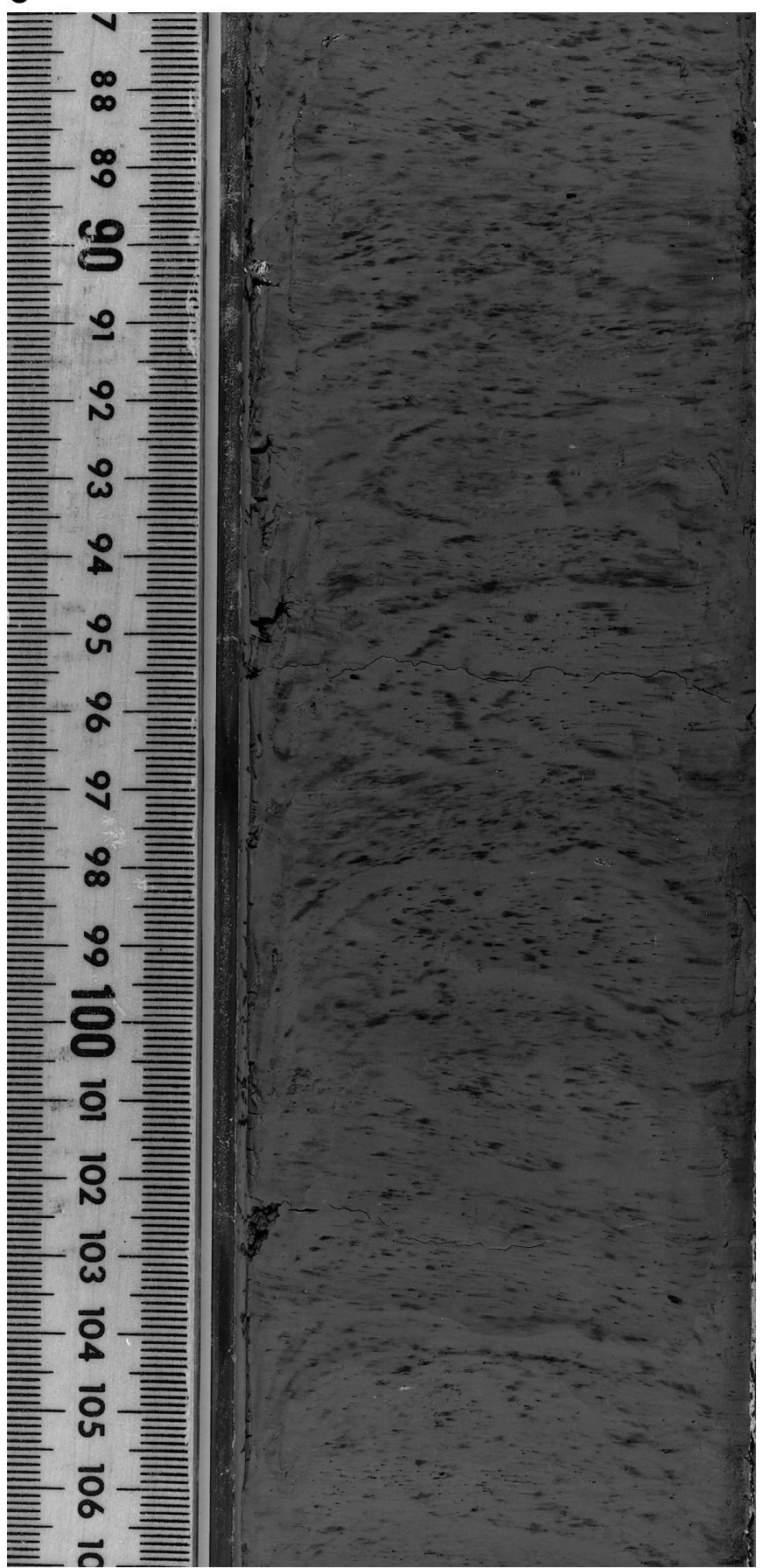

Figure 12 (continued). B. Irregular pattern of color mottling by black hydrotroilite in dark gray bioturbated mud overlying the Yellow Channel-levee System (interval 155-933A-1H-4, 6-22 cm). C. Faint color mottling in bioturbated gray mud overlying the levee of the Amazon Channel. Burrow margins are marked by light-colored pseudolaminae that are free of black hydrotroilite stains (interval 155-939A-4H-3, 87-107 cm).

\section{Lateral Distribution and Relative Abundance of Facies}

The previous discussion and Figure 21 describe the vertical distribution and stacking patterns of sediment facies within the fan. Because Leg 155 drilling was concentrated on the axial portion of the upper and middle fan (Fig. 1), it is not possible to provide facies characterization for the entire fan, except to note that the entire fan is draped by Holocene pelageic/hemipelagic biogenic mud (Facies 13) (Damuth and Kumar, 1975; Damuth, 1977; Flood, Piper, Klaus et al., 1995). The total area of Amazon Fan is $\sim 3.3 \times 10^{5} \mathrm{~km}^{2}$ (Damuth and
Flood, 1985); however, a triangular area that encompasses all but one of the Leg 155 sites (Site 942 is at the extreme western edge of the fan, Fig. 1) covers only $\sim 6.6 \%$ of the total fan area.

As Figure 1 schematically illustrates, channel-levee systems and MTDs, and, the facies that constitute them, comprise most of the upper and middle fan areas (see also Damuth et al., 1988; fig. 1). The WMTD and EMTD together cover $\sim 46 \times 10^{3} \mathrm{~km}^{2}$, or $\sim 14 \%$ of the fan area (Damuth and Flood, 1985). The areal distribution of stacked channel-levee systems and complexes is of comparable size, or slightly larger (Fig. 1); however, because only one channel-levee sys- 
A

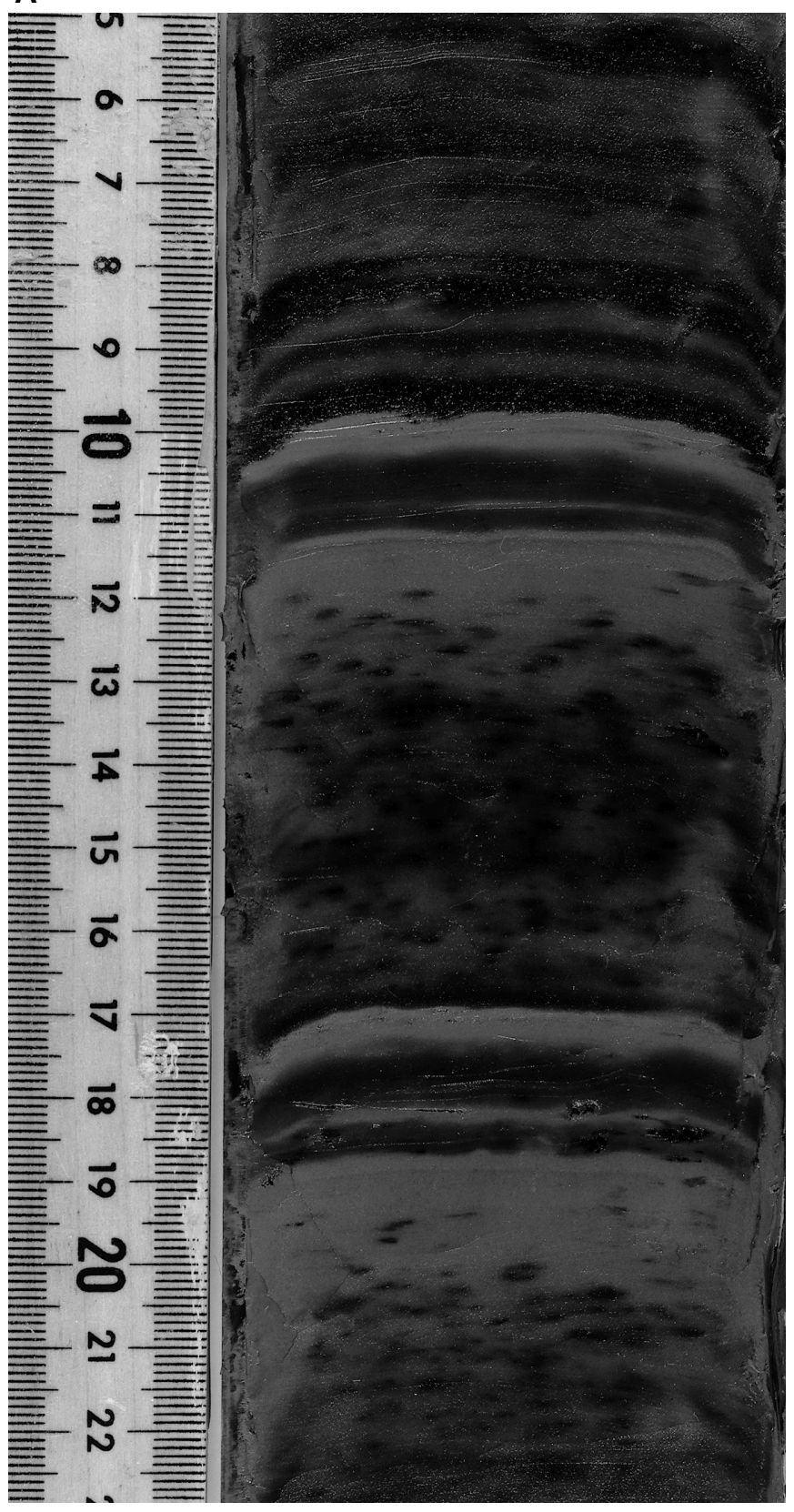

B

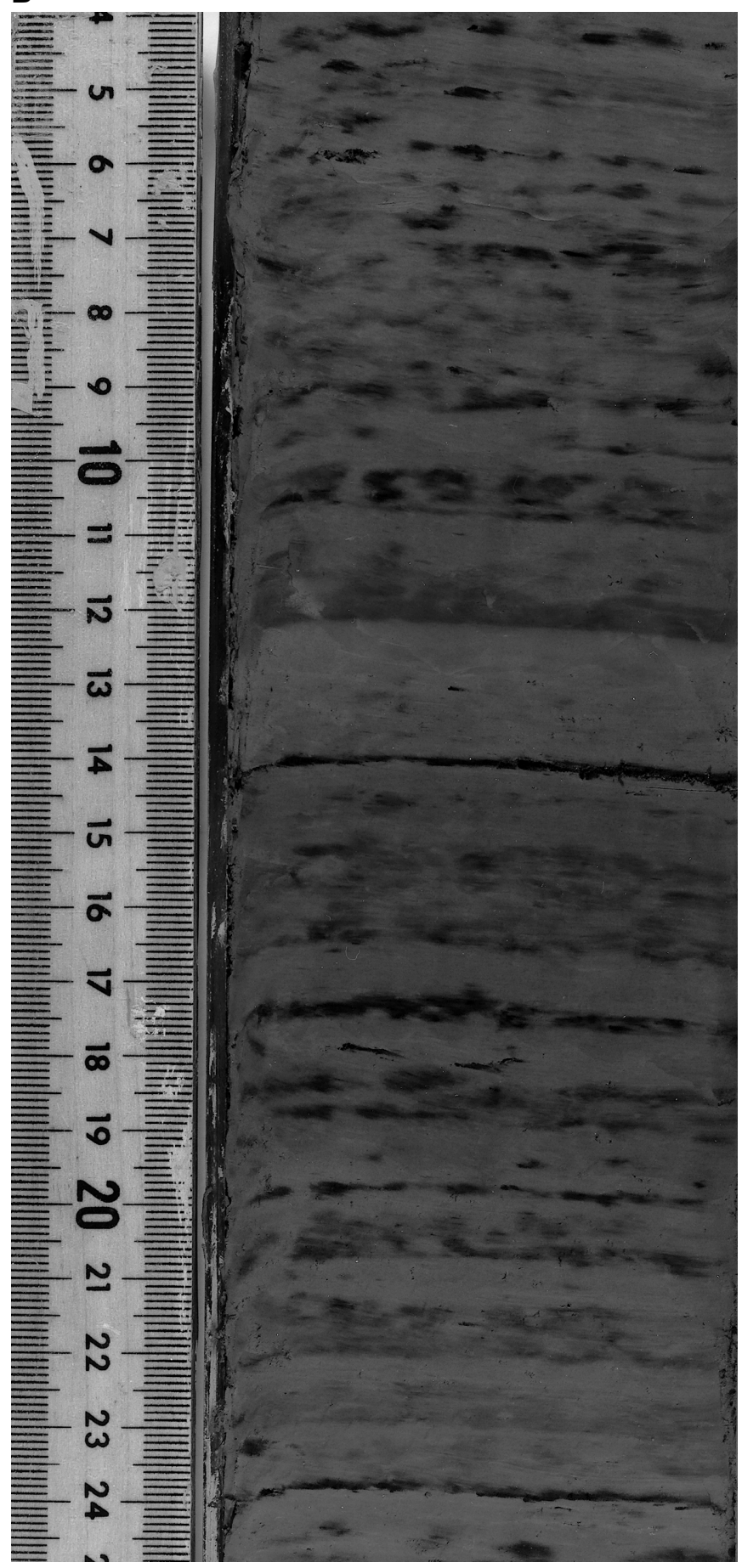

Figure 13. Examples of Facies 9 consist of color-banded clay and mud. A. Color banding in dark gray mud of overbank deposits from the Amazon Channel that fill the channel in the cutoff meander at Site 934 (interval 155-934A-1H-3, 5-23 cm). B. Color banding in the mud of levee deposits (interval 155-942A-9H-2, $4-25 \mathrm{~cm})$.

tem is active at any given time, the area of active channel-floor and levee deposition is only $\sim 2 \%$ of the fan surface. The rest of the upper and middle fan receives pelagic and hemipelagic drape with some contribution from the largest turbidity currents that can spill out of the active channel on the upper fan. Consequently, the sedimentation rates on the levees along the currently active channel are extremely high (10 to $25 \mathrm{~m} / \mathrm{k} . \mathrm{y}$.), whereas the levee crests of abandoned chan- nels and interchannel areas experience much lower rates of sedimentation ( $<1$ to 3 m/k.y.; Damuth, 1977; Shipboard Scientific Party, 1995d; Piper et al., Chapter 39, this volume).

More than half of the total fan lies downslope of the MTDs and the distal terminations of the channel-levee systems and complexes (Damuth et al., 1988; fig. 1). High-resolution (3.5 kHz) seismic-reflection profiles and piston-core data from previous studies suggest 
C

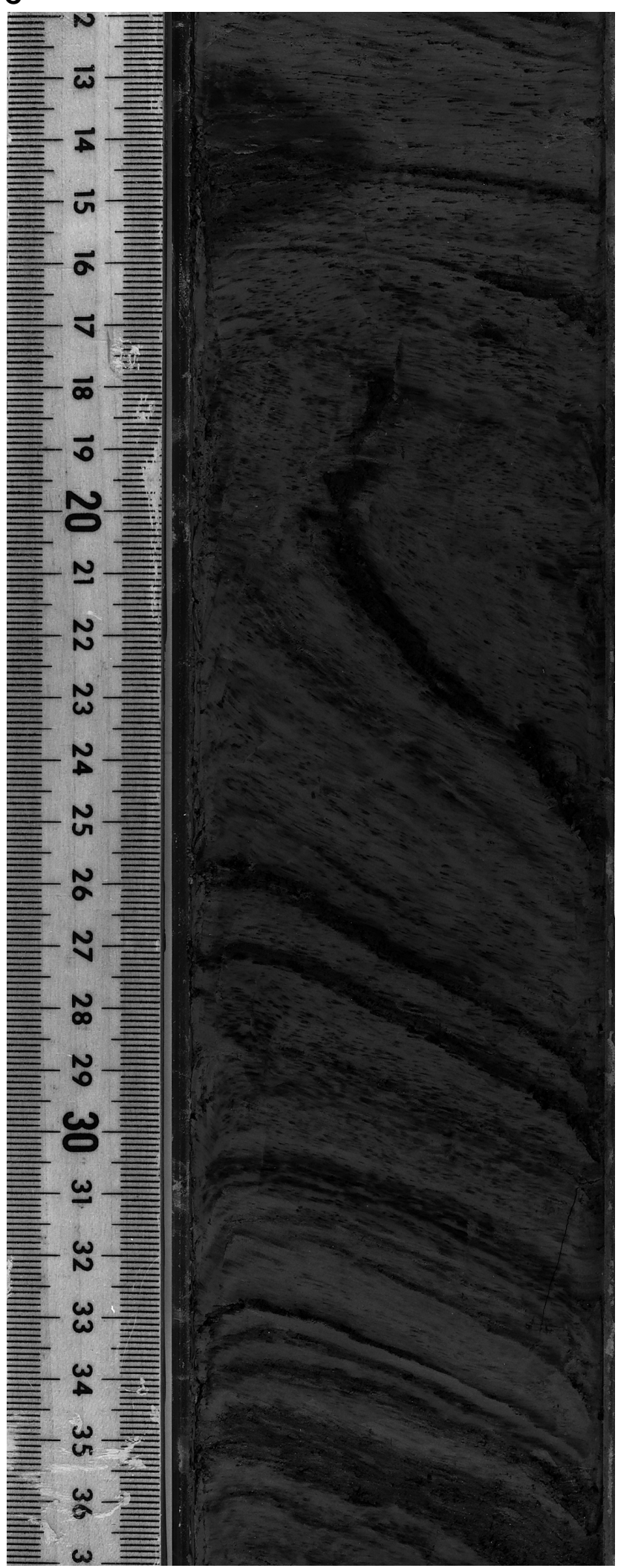

Figure 13. C. Disturbed color-banded mud of levee deposits on the flank of the Amazon Channel-levee System. Deformation and truncation of beds resulted from localized slumping (interval 155-940A-4H-1, 12-37 cm). that the sedimentary facies from this lower fan region are primarily coarse deposits (mainly silt/sand) characteristic of lobe elements or HARP deposits (Damuth, 1975; Damuth and Kumar, 1975). This interpretation is supported by the facies recovered at Sites 945 and 946 on the lower fan, which have been interpreted as predominantly lobe deposits (see Hiscott et al., this volume). Based on the considerations described above (i.e., the concentration of drill sites on the axial portion of the upper and middle fan), we do not believe it is possible to make meaningful measurements or even estimates of the lateral distributions or relative abundances of the various sedimentary facies throughout the fan.

\section{DISCUSSION AND CONCLUSIONS}

The facies distinctions recognized for the Amazon Fan can be used to comment on several aspects of models for turbidite-system and submarine-fan deposition. The purpose of this discussion is not to evaluate existing models, but to look for insights into fan development that have not been confirmed by previous studies. Leg 155 drilling provides a unique opportunity to understand the development of the levee and, to a lesser extent, channel and lower fan-lobe turbidite elements, especially for the youngest part of the Upper Levee Complex (the Aqua, Brown, and Amazon Channels; Shipboard Scientific Party, 1995d; Pirmez and Flood, 1995). Knowledge of the vertical and lateral succession of facies, together with the time frame of deposition (see Piper et al., Chapter 39; Mikkelsen et al; Maslin and Mikkelsen; Cisowski, all in this volume) for these three stages of fan development, meet the criteria for comparable physical and temporal scales of the data needed to understand the long-term depositional processes (Mutti and Normark, 1987, 1991). Although comparable facies distinctions with age control are available for the older leveechannel systems on the central fan, which are ancestral to the Amazon Channel, none of these other systems were penetrated at a sufficient number of sites to understand downfan changes in sedimentary facies. In addition, the extent and resolution of morphologic control is greatest for the more recent parts of the Upper Levee Complex. The following observations are, therefore, based primarily on Leg 155 Sites 930, 936, 939, 940, 944, 946 for the levee element and Sites 934, 943, and 945 for the channel element (Fig. 1; see also sediment logs of plate 1, Shipboard Scientific Party, 1995a and Fig. 3 [backpocket foldout] of Pirmez, et al., this volume).

With the exception of the Holocene biogenic mud (Facies 13), thin-to-thick-bedded organized sand (Facies 3 ) is the only facies common to levee, channel (HAR), and lobe (HARP) deposits (Fig. 21). However, organized sand beds are relatively thin and rare in the levee deposits and generally occur only near the base of the levee sections. Where the core recovery is relatively complete, silty facies common to the levee sequences abruptly overlies coarse-grained facies of lobes (HARPs) and indicates that the levee rapidly progrades over the lobe resulting in an abrupt upward change in facies in the sediment column.

Sand beds of Facies 3 in channel-fill sequences (HARs) are thicker and generally coarser than in the levee deposits (plate 1; Shipboard Scientific Party, 1995a). Facies 2, disorganized sand beds commonly with abundant mud clasts, is relatively common in the channel-fill deposits. The angular shapes of the mud clasts are indicative of relatively limited transport and suggest that erosion and failure of the inner walls of the meandering channels is common. The coarsest and thickest beds (Facies 1 and 2) are found in the HARP deposits, and as observed by Pirmez et al. (this volume), the wireline log interpretation, especially from Sites 944 and 946, suggests that the Amazon Fan should not necessarily be considered a "mud-rich" turbidite system.

The lack of thick-bedded coarse facies in the levee sections, compared to the channel-fill and lobe deposits, indicates that the sand and 
clasts carried through the Amazon channel-levee systems by the larger turbidity currents and related gravity flows generally remain confined within the channel until reaching the active depositional lobe at the channel mouth, unless an avulsion event occurs. The lower, denser parts of these turbidity currents and related gravity flows stay confined within the channel, even when the levee-crest to channel-floor relief is as little as $35 \mathrm{~m}$ (at Sites 945 and 946). Silty-sandy mud and discrete sand beds are common on the lower fan and adjacent Demara Abyssal Plain for at least $300 \mathrm{~km}$ downfan from the deepest water Leg 155 drill sites (945/946) (Damuth and Kumar, 1975; Damuth and Flood, 1985). The echo-character of $3.5 \mathrm{kHz}$ high-resolution reflection profiles is consistent with coarse sediment being deposited across much of the lower fan and adjacent abyssal plain (Damuth, 1975; Damuth and Flood, 1985). The high-resolution profiles also show that numerous unleveed distributary channels occur throughout the lower fan, which extends as far as $250 \mathrm{~km}$ downfan from Sites 945 and 946 . The turbidity currents and related gravity flows moving through the Amazon Fan channel-levee systems are thus "highly efficient" (in the sense of Mutti, 1979; Mutti and Normark, 1991) in transporting sand and gravel for hundreds of kilometers.

The depositional processes inferred for turbidity currents that form the prominent levees on Amazon Fan are presented by Hiscott et al. (this volume) and Piper and Deptuck (this volume). The levees are formed by flow-stripping of the tops of mixed-load turbidity currents where the flow thickness exceeds the levee height; silt and mud within the upper part of the flows moves across and is deposited on the levees. The coarser sediment is concentrated within the lower part of the flow and generally keeps moving downfan (see Hiscott et al., this volume; their Fig. 18 and discussion).

The amount of sediment deposited on the levees relative to the amount that bypasses with the continuing turbidity-current flow within the channel to the lower fan can be evaluated by considering the decrease of channel relief from $\sim 200 \mathrm{~m}$ to $\sim 35 \mathrm{~m}$ along the 650 $\mathrm{km}$ reach of the Amazon Channel (from Pirmez and Flood, 1995). The cross-sectional area decreases from $0.8 \mathrm{~km}^{2}$ to $0.05 \mathrm{~km}^{2}$ along this same reach of channel. As a result, much of the upper part (the upper $80 \%$ of the flow thickness or $94 \%$ of the cross-sectional area) of a turbidity current that could fill or overflow the levees of the active channel on the uppermost fan will be stripped off and deposit sediment to form the prominent levee/overbank deposits. These estimates of flow volume lost by flow stripping minimize the loss of sediment from a bankfull flow because (1) no method exists to evaluate how many turbidity currents exceed bankfull flow on the uppermost fan, and (2) as the flow moves through the channel, continuous entrainment of water occurs and decreases the concentration of sediment within the remaining flow. Nevertheless, the continued downfan transport of silt- and sand-sized sediment across the lower fan well beyond the termination of the channel-levee systems suggests that sufficient fine-grained sediment remains, even after the extensive overbank deposition, to maintain sufficient turbidity-current competence to transport coarse sediment to the distal fan. It appears that the existence of large, dominantly muddy levees might be an indication that the turbidite system is highly efficient for transporting the coarser material to the basin, but are not an indication of a dominantly muddy system.

The lack of medium-bedded and thick-bedded sand deposits in levee deposits and the rarity of sand beds in general, except near the base of levee units, indicates that the levees do not have to be very high before they are effective at confining (as a minimum) the lower parts of the turbidity currents and related gravity flows where sand is transported (Fig. 18 in Hiscott et al., this volume). Entrenchment of the channel floor on the lower fan near the levee termination can help maintain channel relief and help confine the turbidity currents. Accumulation rates on active levees range from 10 to $25 \mathrm{~m} / \mathrm{k}$.y., whereas the sandy lobe areas aggrade at rates averaging only $2 \mathrm{~m} / \mathrm{k}$.y. (Shipboard Scientific Party, 1995d). The much lower average rate of deposition on the lobe implies either that much of the sediment (from
A

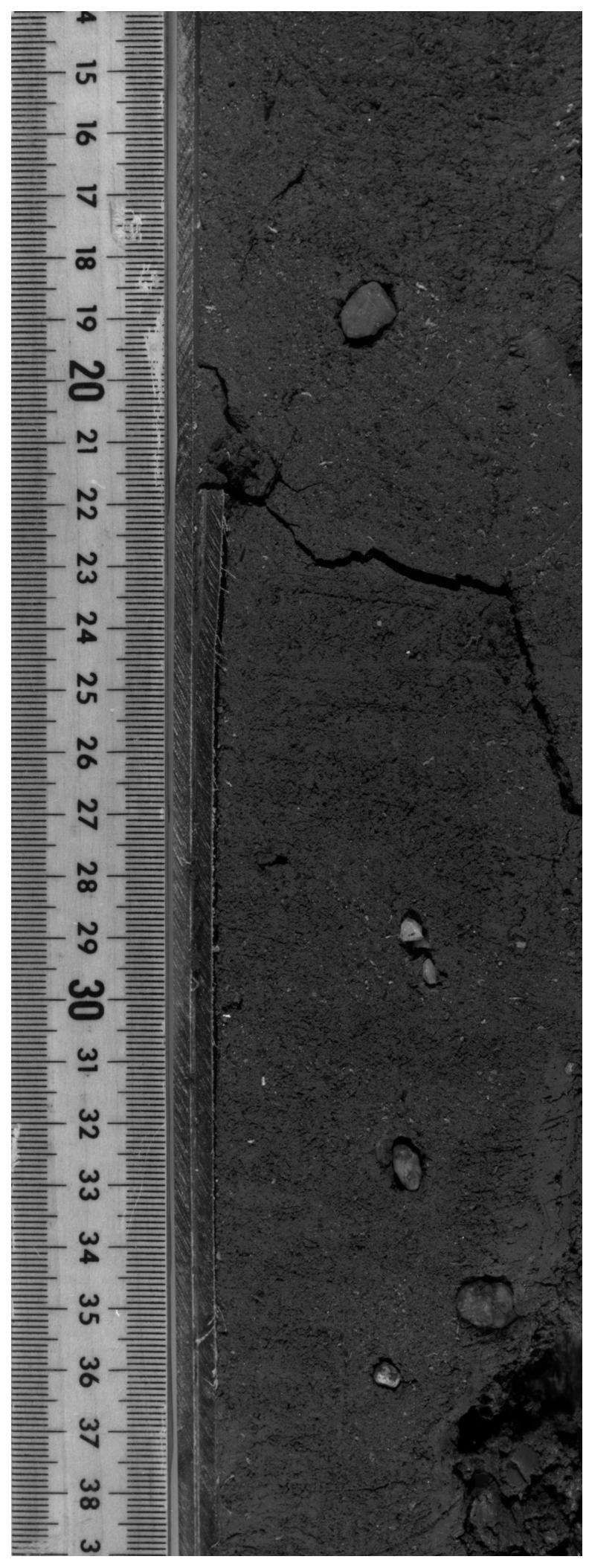

Figure 14. Examples of Facies 11 consist of disorganized pebbly, gravelly, or sandy mud. A. Quartz and rock granules and pebbles scattered through the black sandy mud of an MTD in the HARP unit of the Brown Channel-levee System (interval 155-936A-9H-2, 14-39 cm). 
B

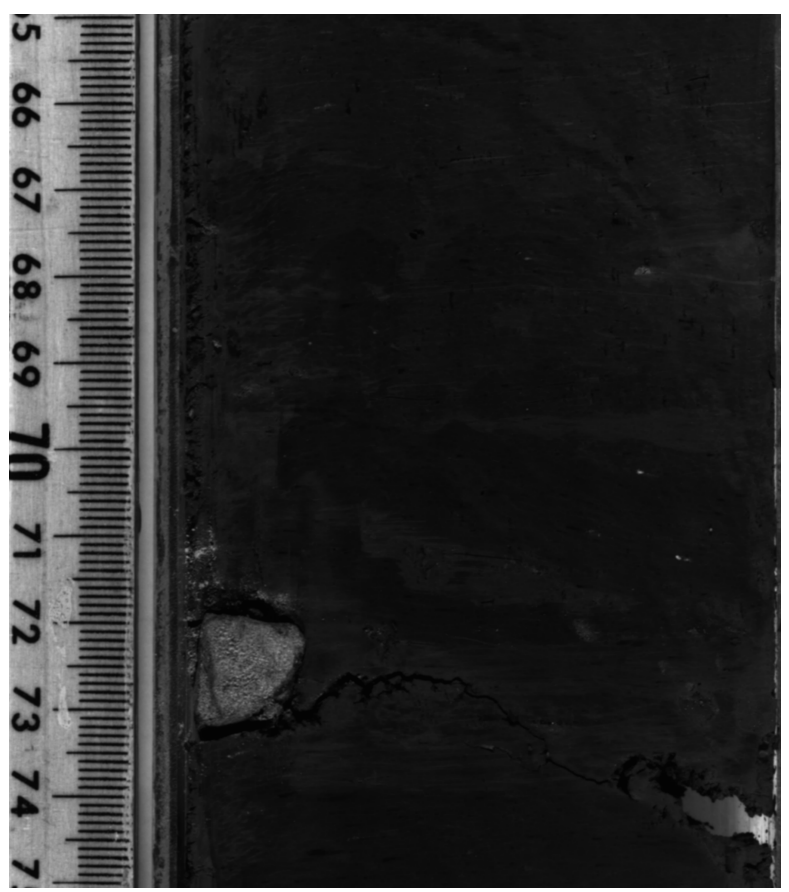

C

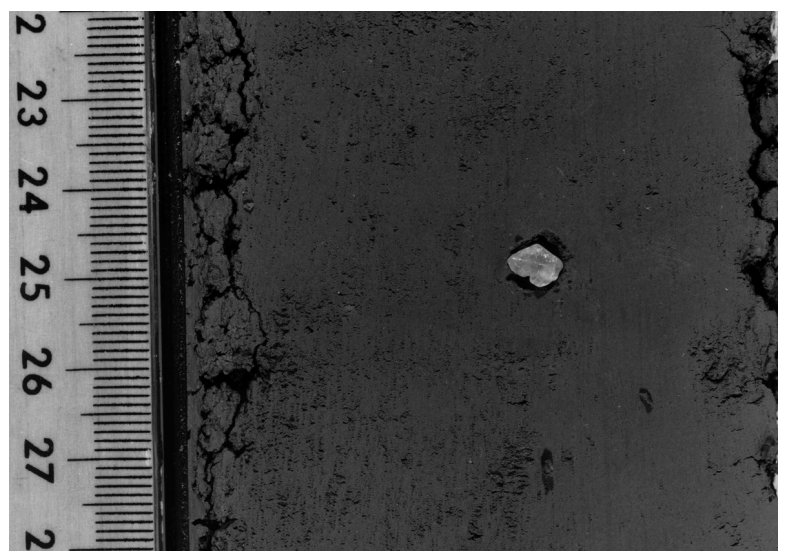

D

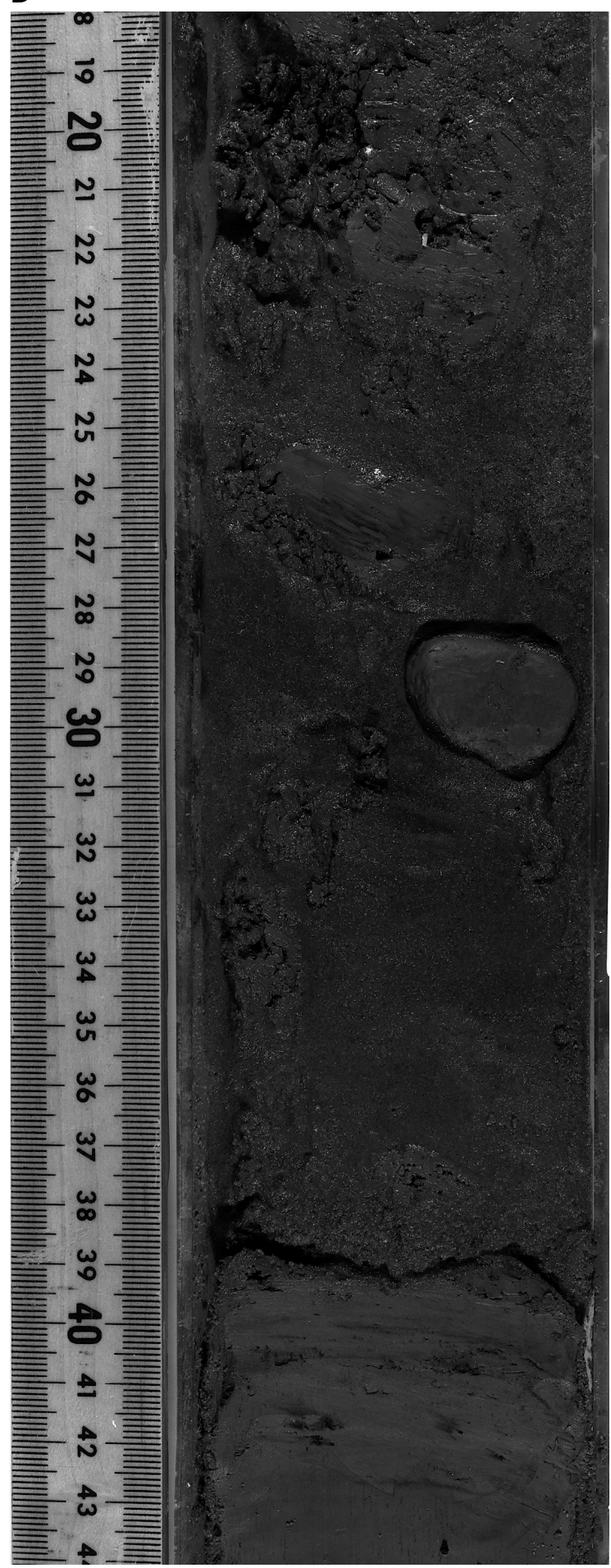

Figure 14 (continued). B. Siltstone pebble in silty clay of the WMTD (interval 155-941B-12H-5, 65-75 cm). C. Subrounded quartz pebble in the massive clayey silt of an MTD (interval 155-930B-21X-4, 22-28 cm). D. Well-rounded, 3-cm diameter, fine-sandstone clast in silty clay (28.5-31 cm) of an MTD in HARP units of the Aqua Channel-levee System (interval 155-935A-22X-1, 18-44 cm). Medium sand above (18-27.5 cm) contains angular mud clasts.

dominantly muddy turbidity currents) moving through the channels is deposited by overbank processes, or that the lower parts of mixedload turbidity currents are able to keep transporting large volumes of sediment downfan, where they spread out across a much wider area on the lower fan (i.e., at any given moment, the active levee-channel system covers only $\sim 2 \%$ of the fan surface). Because the entire lower fan appears to have abundant silt and sand beds (Damuth, 1973; Damuth and Flood, 1985), the latter explanation seems most likely.

Avulsion events that create major new channel systems apparently occur every 5 to $10 \mathrm{k} . y$., and new channel-levee systems rapidly advance downfan for distances of as much as $100 \mathrm{~km}$ in similar time intervals (Pirmez and Flood, 1995). The rate of downfan advance of 
A

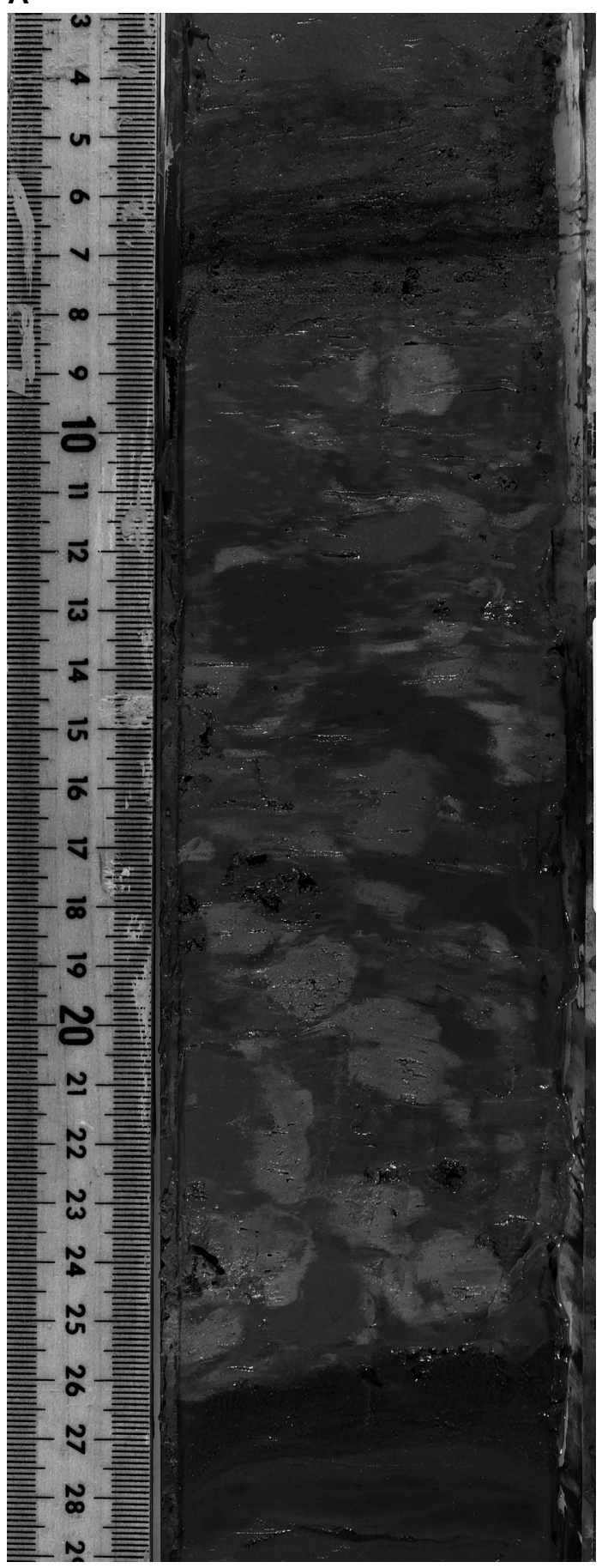

B

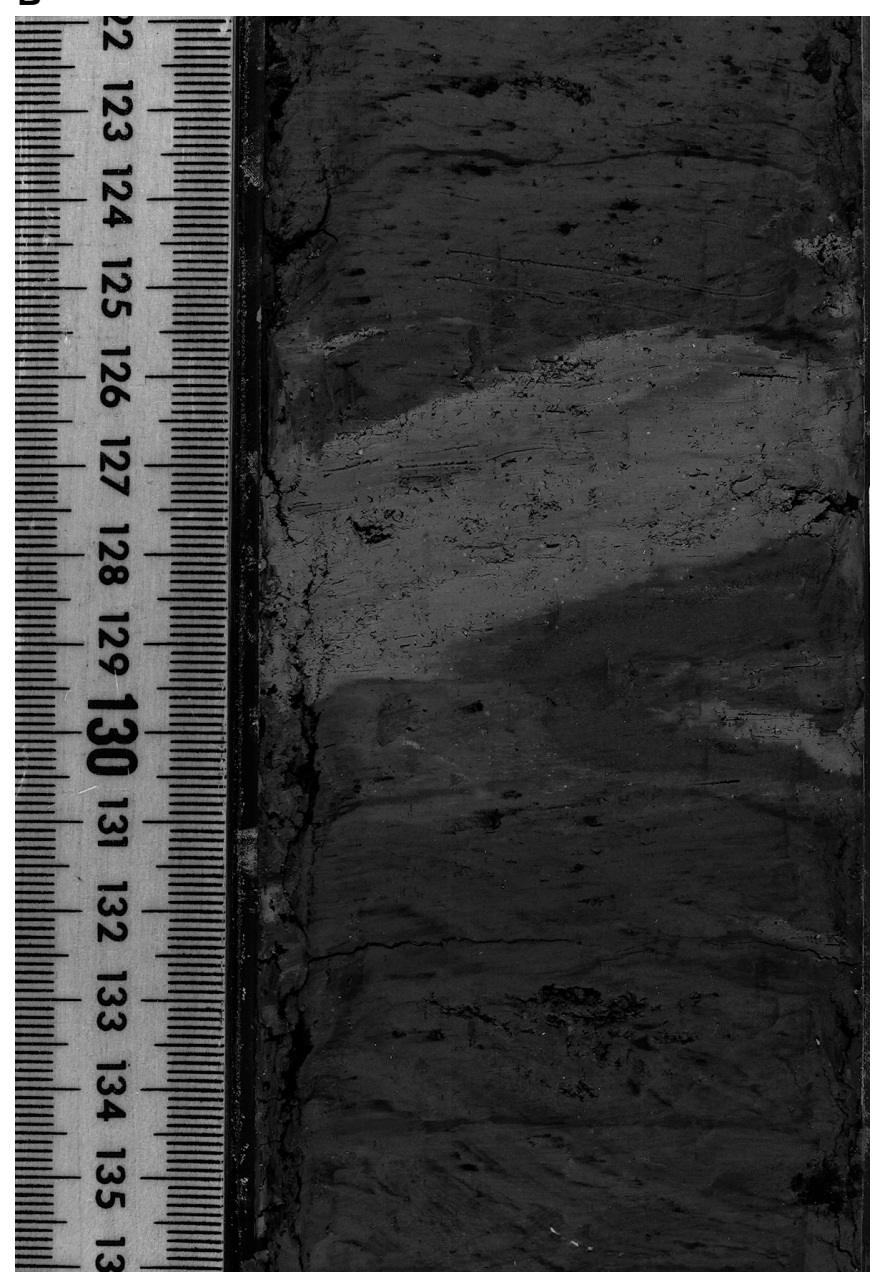

Figure 15. Examples of Facies 12 consist of deformed or chaotic mud with clasts. A. Thin MTD of gray clay containing lighter colored clasts of foraminifer clay (interval 155-934A-1H-1, 3-29 cm). B. A small carbonate-rich mud clast (126-129.5 cm) in gray mud of an MTD (interval 155-931B-36X-6, 122-136 cm).

the levee termination zone of an active channel-levee system therefore can be as much as $20 \mathrm{~m} / \mathrm{yr}$. If a levee system aggraded at this same rate, it would take only $10 \mathrm{yr}$ to construct an average-sized elevated levee system. Downcutting of the channel floor combined with lateral spreading of the turbidity currents, which initiate overbank deposition in the levee termination zone, rapidly establish sufficient levee-to-channel floor relief to begin effectively confining the sandier parts of the flows. The levees continue to aggrade until only the muddy tops of the largest turbidity currents are able to overflow and deposit sediment (see plate 1; Shipboard Scientific Party, 1995a).
Sand is rapidly deposited in front of the channel mouth as the turbidity currents become unconfined downfan of the levee termination zone. These coarse-grained deposits, composed primarily of Facies 1 through 3, form depositional lobes, which form (as a minimum) the upper parts of the HARP units. The rapidly advancing channel-levee system progrades over these lobes; thus, these lobes or HARP units form essentially contemporaneously with the channel that feeds them.

Insufficient sites were drilled in channel-fill and depositional-lobe elements during Leg 155 to provide clear insights regarding the mod- 
C

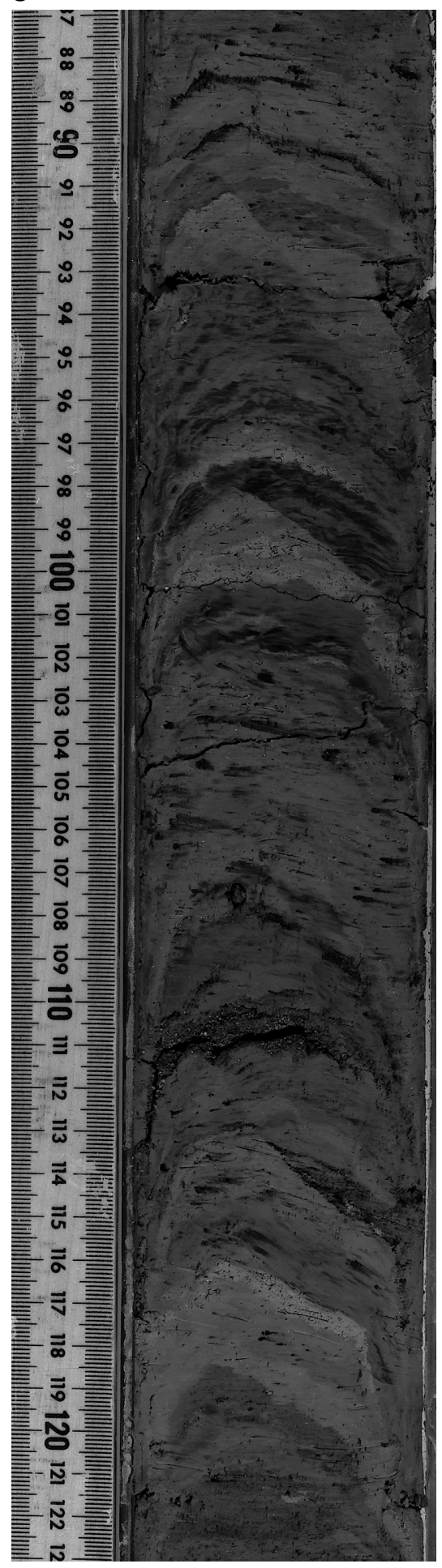

D

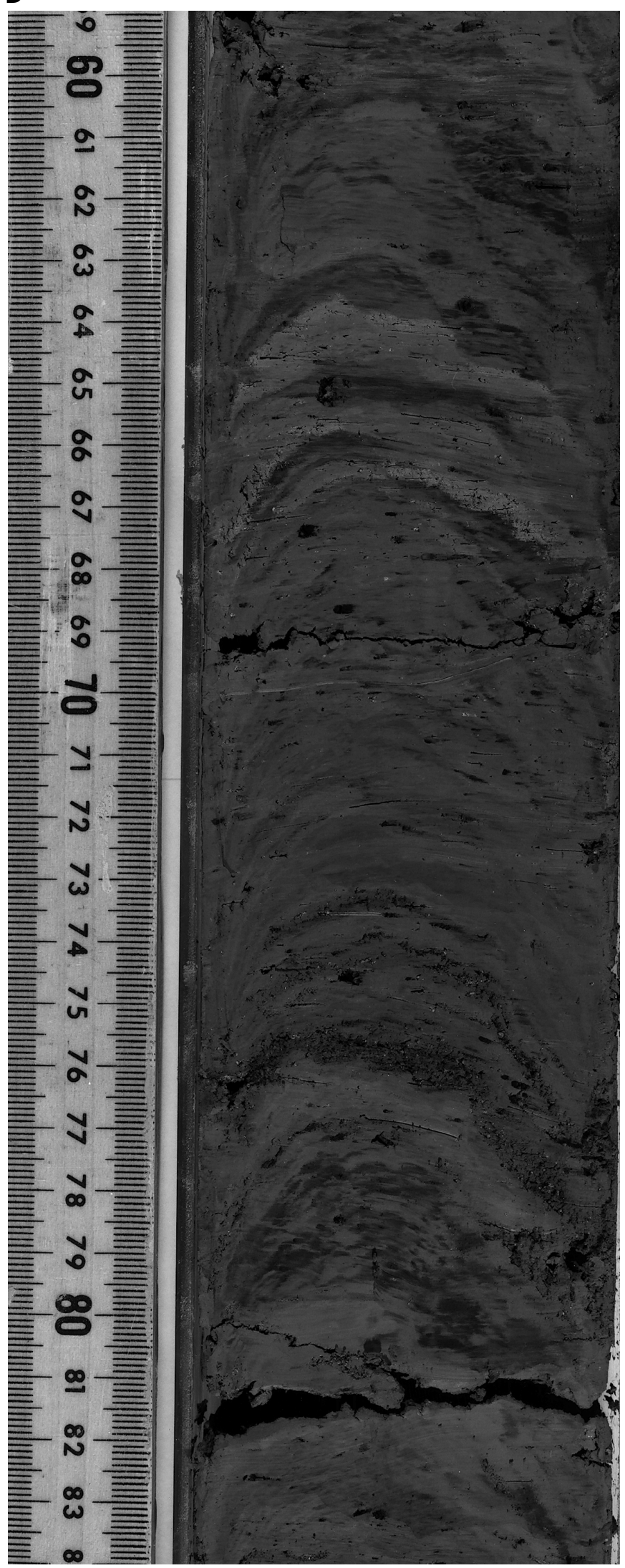

Figure 15 (continued). C. Folded, faulted, and deformed mud clasts of variegated color and contrasting lithologies in the WMTD. A lithic pebble occurs at 108 $\mathrm{cm}$ and X-radiographs show additional pebbles and shell fragments in this section of core (interval 155-941A-4H-5, 87-123 cm). D. Folded, faulted, and deformed mud clasts of variegated color and contrasting lithologies in the WMTD (interval 155-941A-4H-5, 59-84 cm). 
A

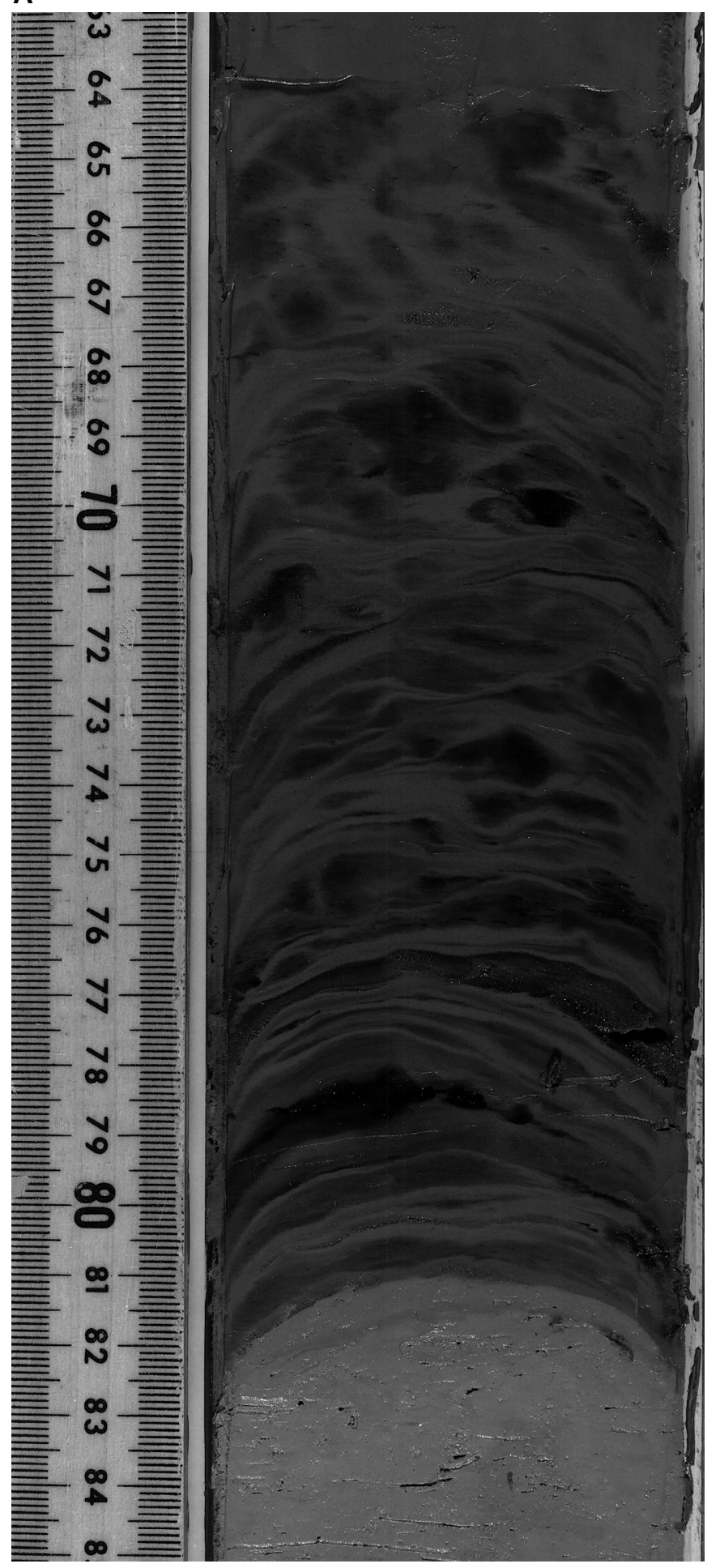

B

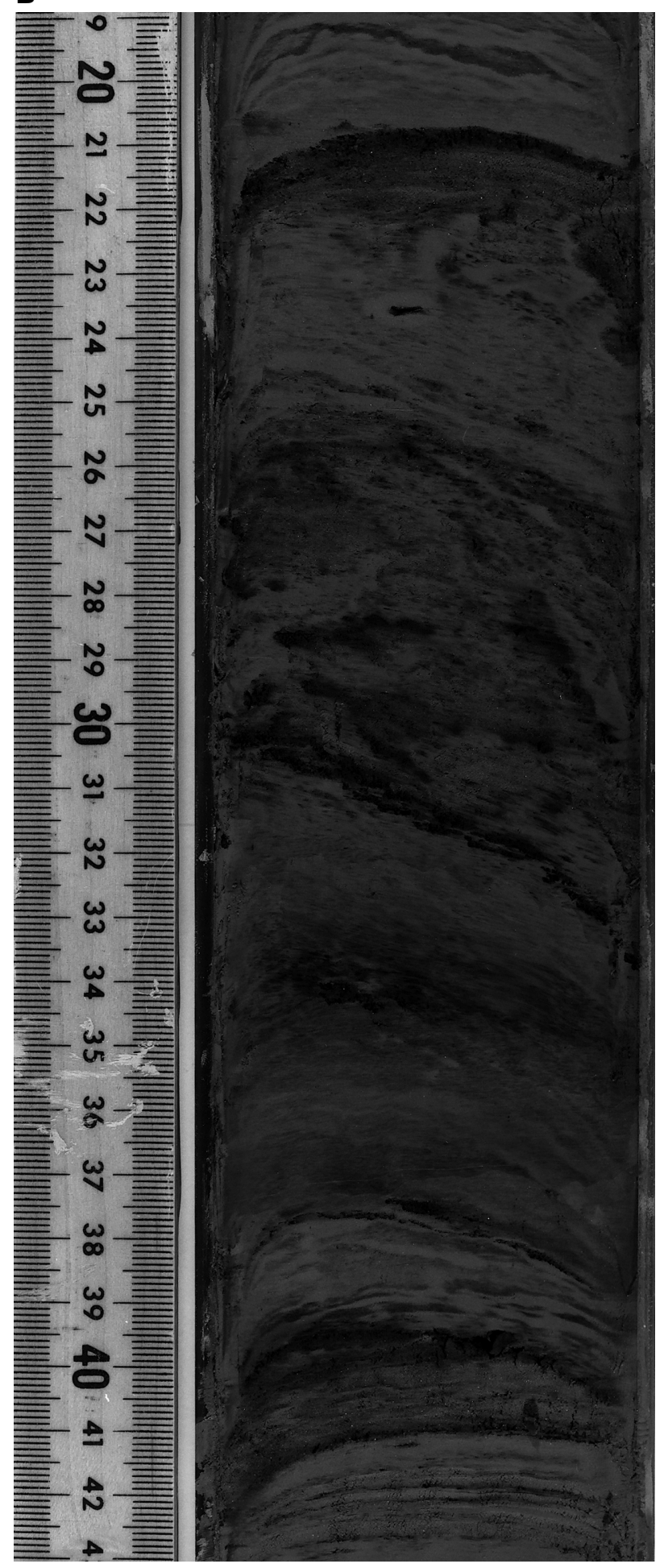

Figure 16. Examples of Facies 12 consist of deformed or chaotic mud with contorted and folded strata. A. Thin MTD with deformed and truncated clay laminae of variegated gray color (interval 155-943A-1H-1, 63-85 cm). B. Deformed, contorted, and folded color-banded mud in a local slump deposit in the levee on the Amazon Channel-levee System (interval 155-940A-3H-5, 19-43 cm). 
C

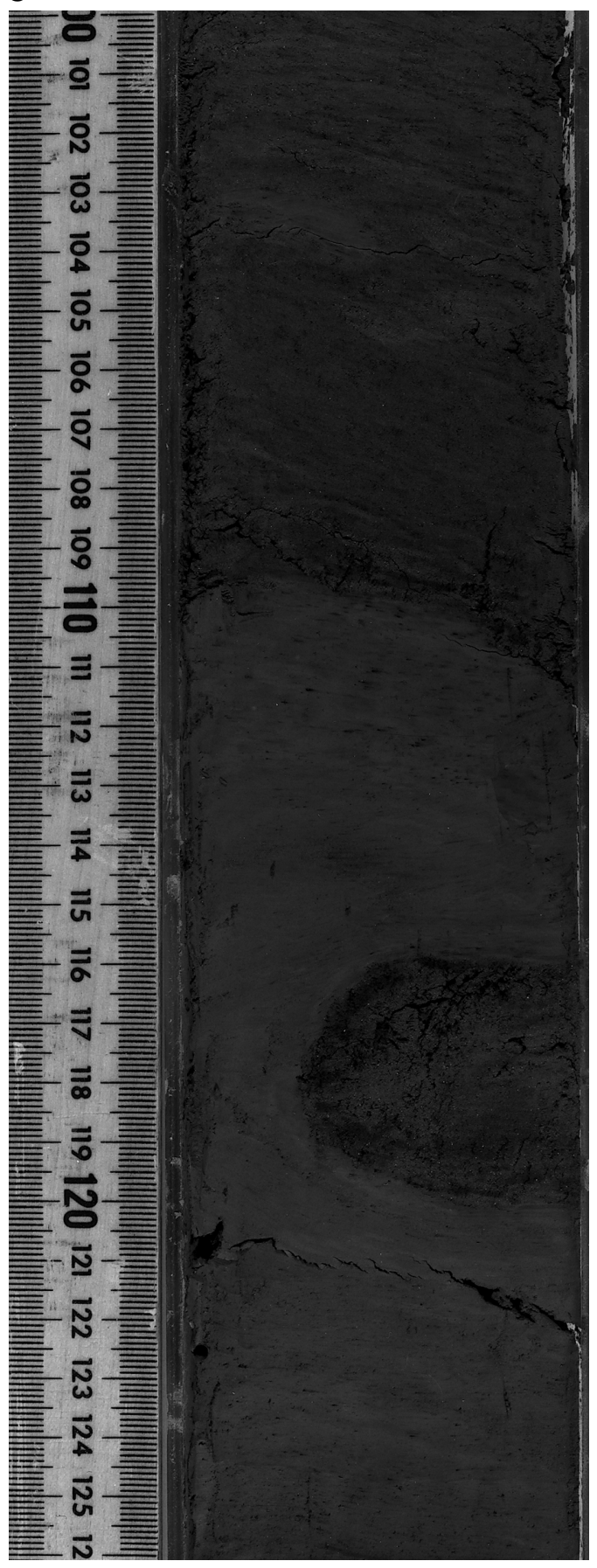

D

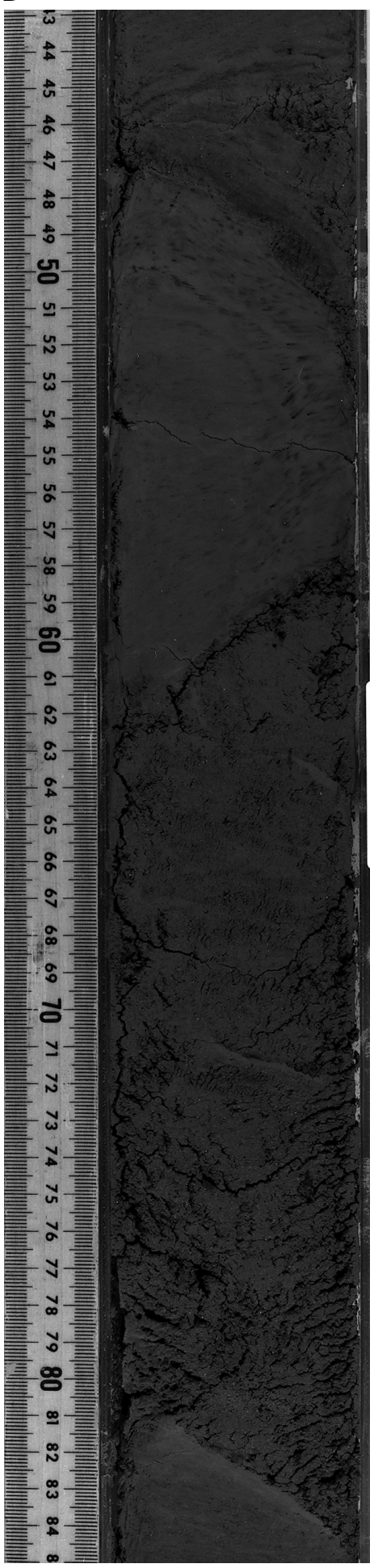

Figure 16 (continued). C. Contorted, folded mud, and sandy mud in local slump deposits within the levee of the Amazon Channel-levee System. Note fold from 110-126 cm with sandy core (114-120 cm; interval 155-944A-5H-1, 100-126 cm). D. Contorted, folded mud, and sandy mud in local slump deposits within the levee of the Amazon Channel-levee System (interval 155-944A-5H-1, 43-85 cm). 
A

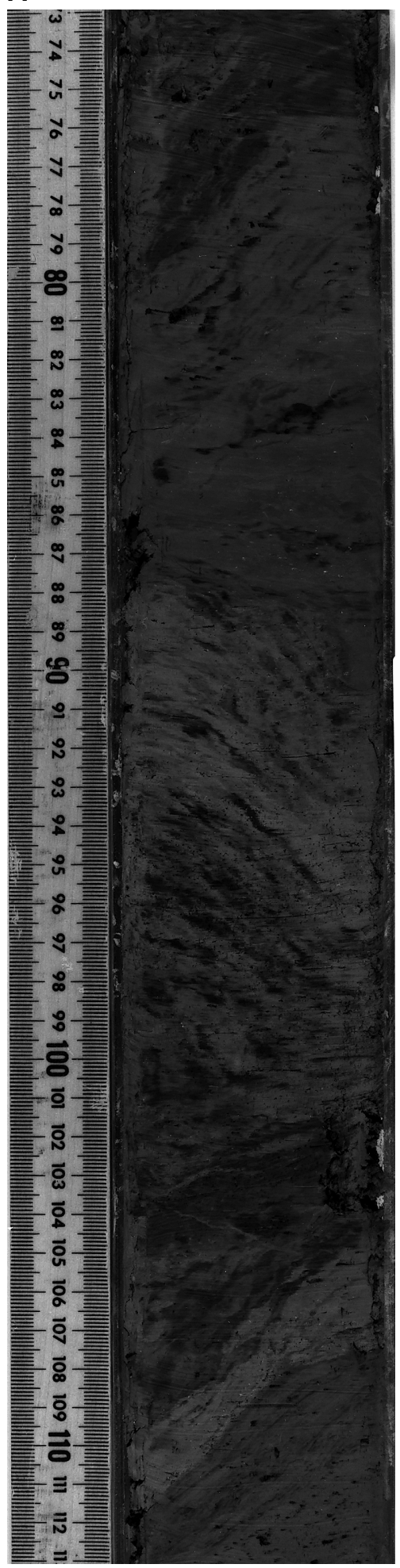

B

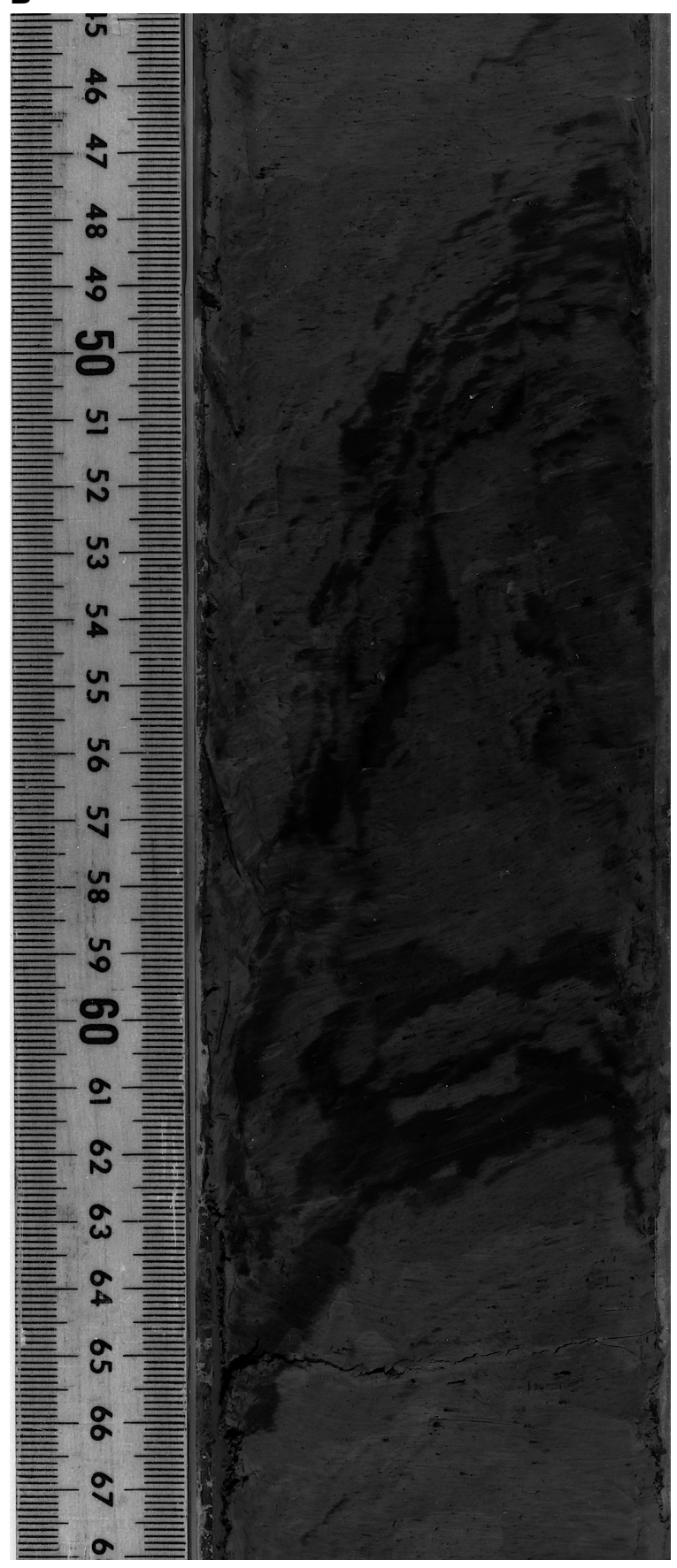

Figure 17. Examples of Facies 12 consist of deformed or chaotic mud with discordant, truncated, and faulted strata. A. Discordant, truncated, contorted, and "crenulated" mud in the Unit R MTD (interval 155-944A-25X-5, 73-113 cm). B. Steeply dipping "crenulated," deformed color bands and beds, and discordant contacts in mud of the WMTD (interval 155-941A-3H-7, 45-68 cm). 
C

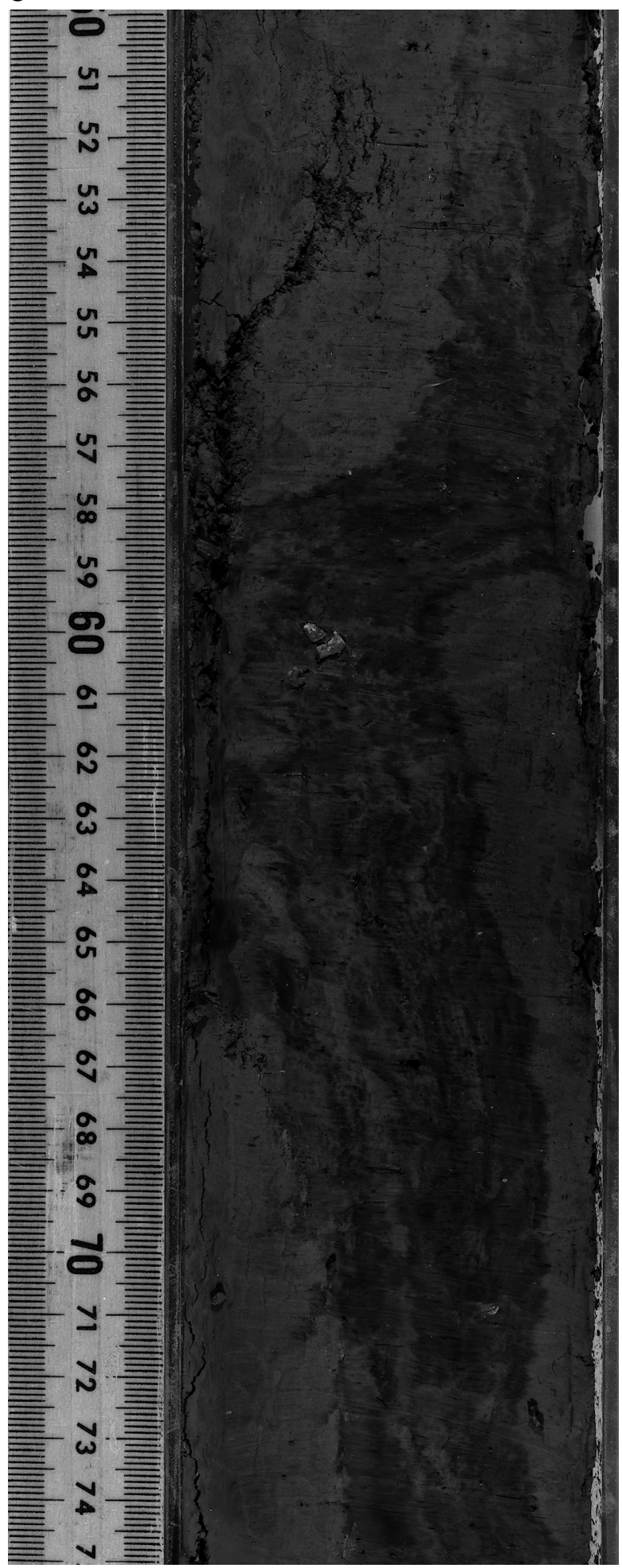

Figure 17 (continued). C. Folded and contorted bedding and color bands in the Unit R MTD (interval 155-944A-25X-3, 50-75 cm). els of asymmetric (thinning and fining upward and thickening and coarsening upward) cycles commonly used to identify channel-fill and lobe deposits, respectively, in outcrop and boreholes (e.g., Mutti and Ricci Lucchi, 1972; Mutti, 1979). Drilling did, however, provide excellent facies definition for several MTDs that are a common element on many submarine turbidite systems (Piper et al., Chapter 6, this volume).

\section{ACKNOWLEDGMENTS}

J. Damuth was supported during this study by JOI-USSSP Grant 155-20843b and National Science Foundation Grant OCE-9504322. W. Normark is grateful to the U.S. Geological Survey for allowing him to participate in Leg 155 and to conduct this post-cruise study. We thank B.T. Cronin, R.G. Walker, and F. Ricci Lucchi for critical and insightful reviews of this manuscript.

\section{REFERENCES}

Barnes, N.E., and Normark, W.R., 1985. Diagnostic parameters for comparing modern submarine fans and ancient turbidite systems. In Bouma, A.H., Normark, W.R., and Barnes, N.E. (Eds.), Submarine Fans and Related Turbidite Systems: New York (Springer-Verlag), 13-14.

Bouma, A.H., Coleman, J.M., Meyer, A.W., et al., 1986. Init. Repts. DSDP, 96: Washington (U.S. Govt. Printing Office).

Damuth, J.E., 1973. The western Equatorial Atlantic: morphology, Quaternary sediments, and climatic cycles [Ph.D. dissert.]. Columbia Univ., New York.

1975. Echo character of the western Equatorial Atlantic floor and its relationship to the dispersal and distribution of terrigenous sediments. Mar. Geol., 18:17-45.

1977. Late Quaternary sedimentation in the western Equatorial Atlantic. Geol. Soc. Am. Bull., 88: 695-710.

Damuth, J.E., and Embley, R.W., 1981. Mass-transport processes on the Amazon Cone: western equatorial Atlantic. AAPG Bull., 65: 629-643.

Damuth, J.E., and Fairbridge, R.W., 1970. Equatorial Atlantic deep-sea arkosic sands and ice-age aridity in tropical South America: Geol. Soc. Am. Bull., 81:189-206.

Damuth, J.E., and Flood, R.D., 1985. Amazon Fan, Atlantic Ocean. In Bouma, A.H., Normark, W.R., and Barnes, N.E. (Eds.), Submarine Fans and Related Turbidite Systems: New York (Springer-Verlag), 97-106.

Damuth, J.E., Flood, R.D., Kowsmann, R.O., Belderson, R.H., and Gorini, M.A., 1988. Anatomy and growth pattern of Amazon deep-sea fan as revealed by long-range side-scan sonar (GLORIA) and high-resolution seismic studies. AAPG Bull., 72:885-911.

Damuth, J.E., and Kumar, N., 1975. Amazon Cone: morphology, sediments, age and growth pattern. Geol. Soc. Am. Bull., 86:863-878.

Damuth, J.E., Kowsmann, R.O., Flood, R.D., Belderson, R.H., and Gorini, M.A., 1983. Age relationships of distributary channels on Amazon deepsea fan: implications for fan growth pattern. Geology, 11:470-473.

Ericson, D.B., Ewing, M., Wollin, G., and Heezen, B.C., 1961. Atlantic deepsea sediment cores. Geol. Soc. Am. Bull.,72:193-286.

Flood, R.D., Manley, P.L., Kowsmann, R.O., Appi, C.J., and Pirmez, C., 1991. Seismic facies and late Quaternary growth of Amazon submarine fan. In Weimer, P., and Link, M.H. (Eds.), Seismic Facies and Sedimentary Processes of Submarine Fans and Turbidite Systems: New York (Springer), 415-433.

Flood, R.D., Piper, D.J.W., Klaus, A., et al., 1995. Proc. ODP, Init. Repts., 155: College Station, TX (Ocean Drilling Program).

Flood, R.D., Piper, D.J.W., and Shipboard Scientific Party, 1995. Introduction. In Flood, R.D., Piper, D.J.W., Klaus, A., et al., Proc. ODP, Init. Repts., 155: College Station, TX (Ocean Drilling Program), 5-16.

Ingram, R.L., 1954. Terminology for the thickness of stratification units and parting units in sedimentary rocks. Geol. Soc. Am. Bull., 65:937-938.

Manley, P.L., and Flood, R.D., 1988. Cyclic sediment deposition within Amazon deep-sea fan. AAPG Bull., 72:912-925.

McGeary, D.F.R., and Damuth, J.E., 1973. Postglacial iron-rich crusts in hemipelagic deep-sea sediment: Geol. Soc. Am. Bull., 84:1201-1212.

Mutti, E., 1979. Turbidites et cones sous-marins profonds. In Homewood, P. (Ed.), Sedimentation Detritique (Fluviatile, Littorale et Marine): Université de Fribourg, Suisse (Institut de Geologie), 353-419. 
Mutti, E., and Normark, W.R., 1987. Comparing examples of modern and ancient turbidite systems: problems and concepts. In Leggett, J.K., and Zuffa, G.G. (Eds.), Marine Clastic Sedimentology: London (Graham and Trotman), 1-38.

- 1991. An integrated approach to the study of turbidite systems. In Weimer, P., and Link, M.H. (Eds.), Seismic Facies and Sedimentary Processes of Modern and Ancient Submarine Fans: New York (SpringerVerlag), 75-106.

Mutti, E., and Ricci Lucchi, F., 1972. Le torbiditi dell'Appennino settentrionale: introduzione all'analisi di facies. Mem. Soc. Geol. Ital., 11:161-199.

Normark, W.R., Posamentier, H., and Mutti, E., 1993. Turbidite systems: state of the art and future directions. Rev. Geophys., 31:91-116.

Pickering, K.T., Stow, D.A.V., Watson, M., and Hiscott, R.N., 1986. Deepwater facies, processes and models: a review and classification scheme for modern and ancient sediments. Earth-Sci. Rev., 23:75-174.

Pirmez, C., and Flood, R.D., 1995. Morphology and structure of Amazon Channel. In Flood, R.D., Piper, D.J.W., Klaus, A., et al., Proc. ODP, Init. Repts., 155: College Station, TX (Ocean Drilling Program), 23-45.

Richardson, D.S., 1974. The origin of iron-rich layers in sediments of the western Equatorial Atlantic Ocean [Ph.D. dissert]. Columbia Univ., New York.

Shipboard Scientific Party, 1995a. Amazon channel-levee longitudinal profile. Flood, R.D., Piper, D.J.W., Klaus, A., et al., 1995. Proc. ODP, Init. Repts., 155: College Station, TX (Ocean Drilling Program), Plate 1, back pocket. 1995b. Amazon Fan strike sections, upper levee complex. Flood, R.D., Piper, D.J.W., Klaus, A., et al., 1995. Proc. ODP, Init. Repts., 155: College Station, TX (Ocean Drilling Program), Plate 2, back pocket.

1995c. Explanatory notes. In Flood, R.D., Piper, D.J.W., Klaus, A., et al., 1995. Proc. ODP, Init. Repts., 155: College Station, TX (Ocean Drilling Program), 47-81.

1995d. Leg synthesis. In Flood, R.D., Piper, D.J.W., Klaus, A., et al., 1995. Proc. ODP, Init. Repts., 155: College Station, TX (Ocean Drilling Program), 17-21.

Showers, W.J., and Bevis, M., 1988. Amazon Cone isotopic stratigraphy: evidence for the source of the tropical meltwater spike. Palaeogeogr., Palaeoclimatol., Palaeoecol., 64:189-199.

Vail, P.R., Audemard, F., Bowman, S.A., Eisner, P.N., and Perez-Cruz, G., 1991. The stratigraphic signatures of tectonics, eustasy, and sedimentology an overview. In Einsele, G., Ricken, W., and Seilacher, A. (Eds.), Cycles and Events in Stratigraphy: Berlin (Springer), 617-659.

Date of initial receipt: 13 June 1996

Date of acceptance: 7 October 1996

Ms 155SR-247 
A

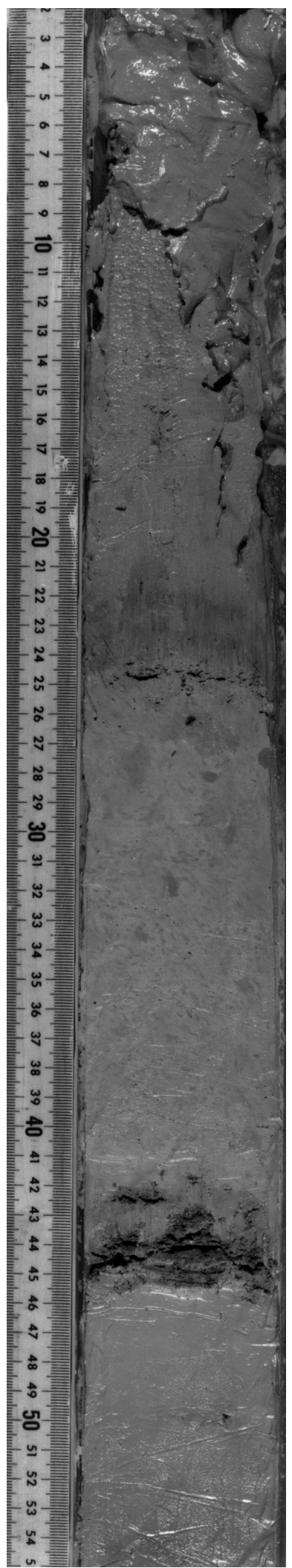

B

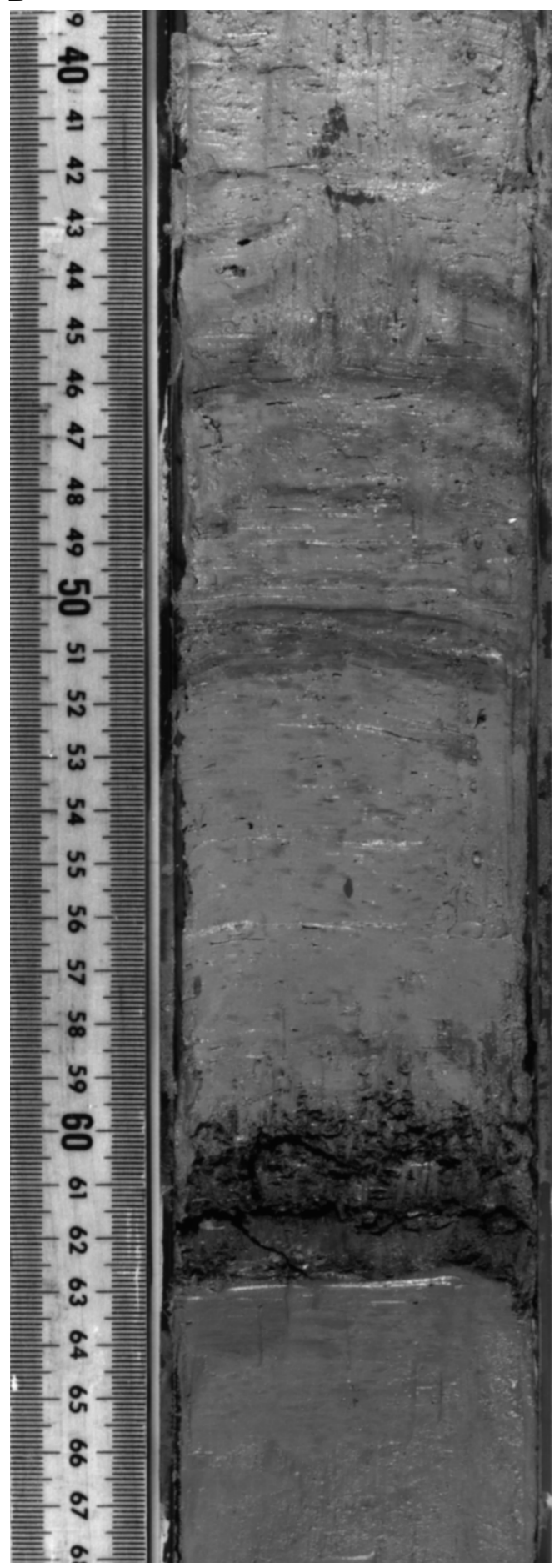

Figure 18. Examples of Facies 13 consist of biogenic mud with interbeds of Facies 15 (chemogenic sediment). A. Biogenic sediment composed of brown (0-24 $\mathrm{cm})$ to gray-brown $(24-42 \mathrm{~cm}$ and $45-55 \mathrm{~cm}$ ) calcareous clay. The dark layer from 42 to $45 \mathrm{~cm}$ is a diagenetic, rust-colored iron-rich crust that represents chemogenic sediment (see text; interval 155-930B-1H-1, 2-55 cm). B. Biogenic sediment composed of brown to gray-brown (39-60 cm) calcareous clay. The dark layer from 60 to $63 \mathrm{~cm}$ is a diagenetic, rust-colored iron-rich crust that represents chemogenic sediment (see text). Gray terrigeneous clay occurs below 63 cm (interval 155-931C-1H-1, 39-68 cm). 


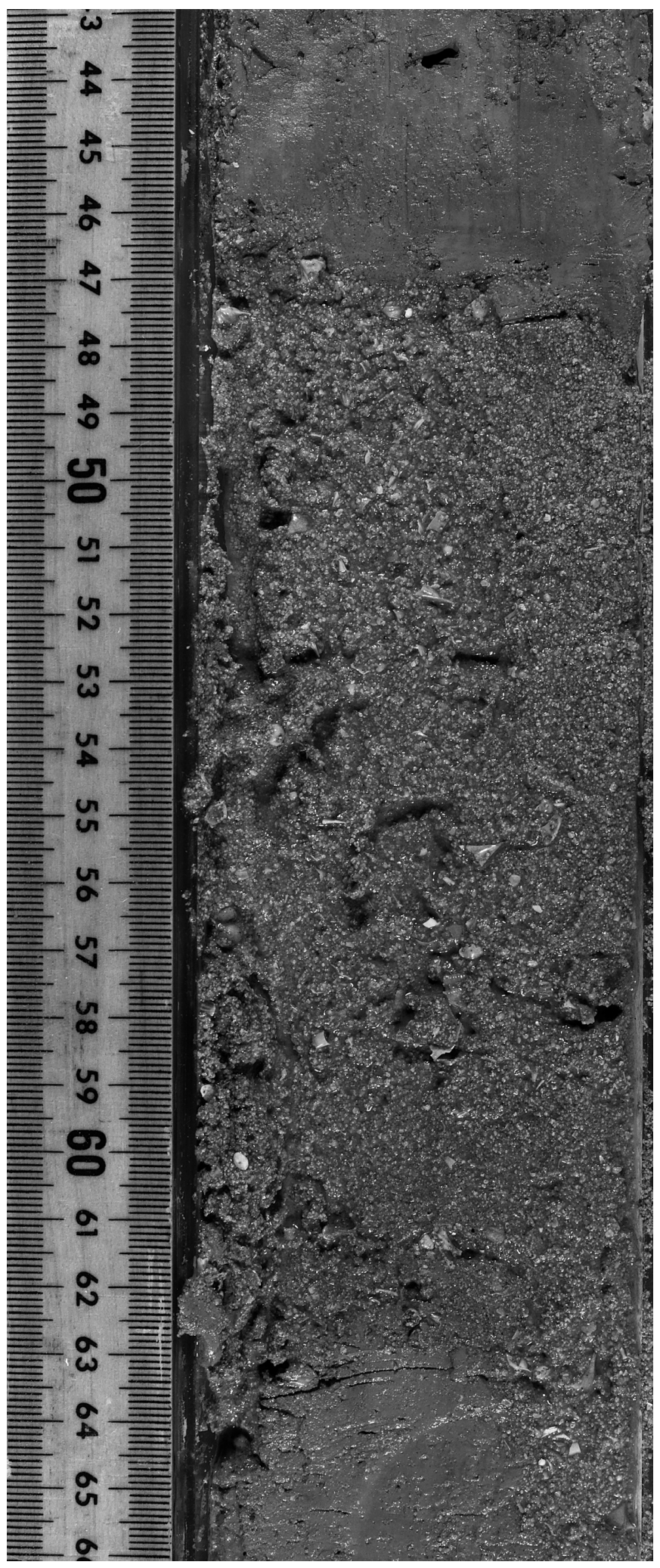

Figure 19. Example of Facies 14 consists of biogenic sand that is a normallygraded, redeposited bed of foraminifer sand with pteropods (interval 155941 A-1H-1, 43-66 cm).

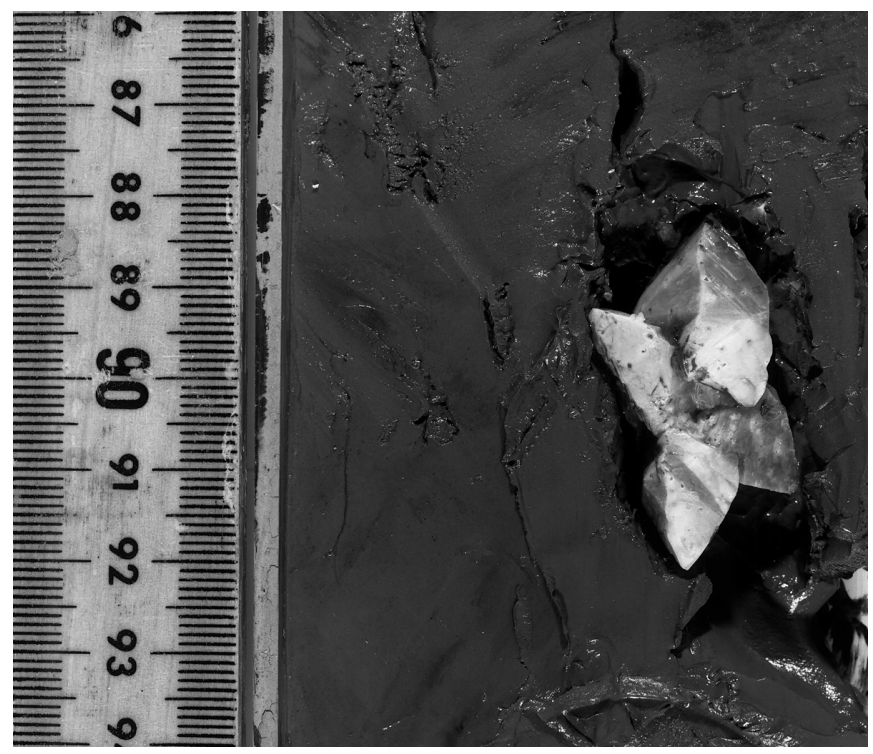

Figure 20. Example of Facies 15 is the crystal of ikaite $\left(\mathrm{CaCO}_{3} \cdot 6 \mathrm{H}_{2} \mathrm{O}\right)$, a diagenetic mineral in gray terrigeneous mud (interval 155-941A-1H-3, 86$94 \mathrm{~cm})$. 


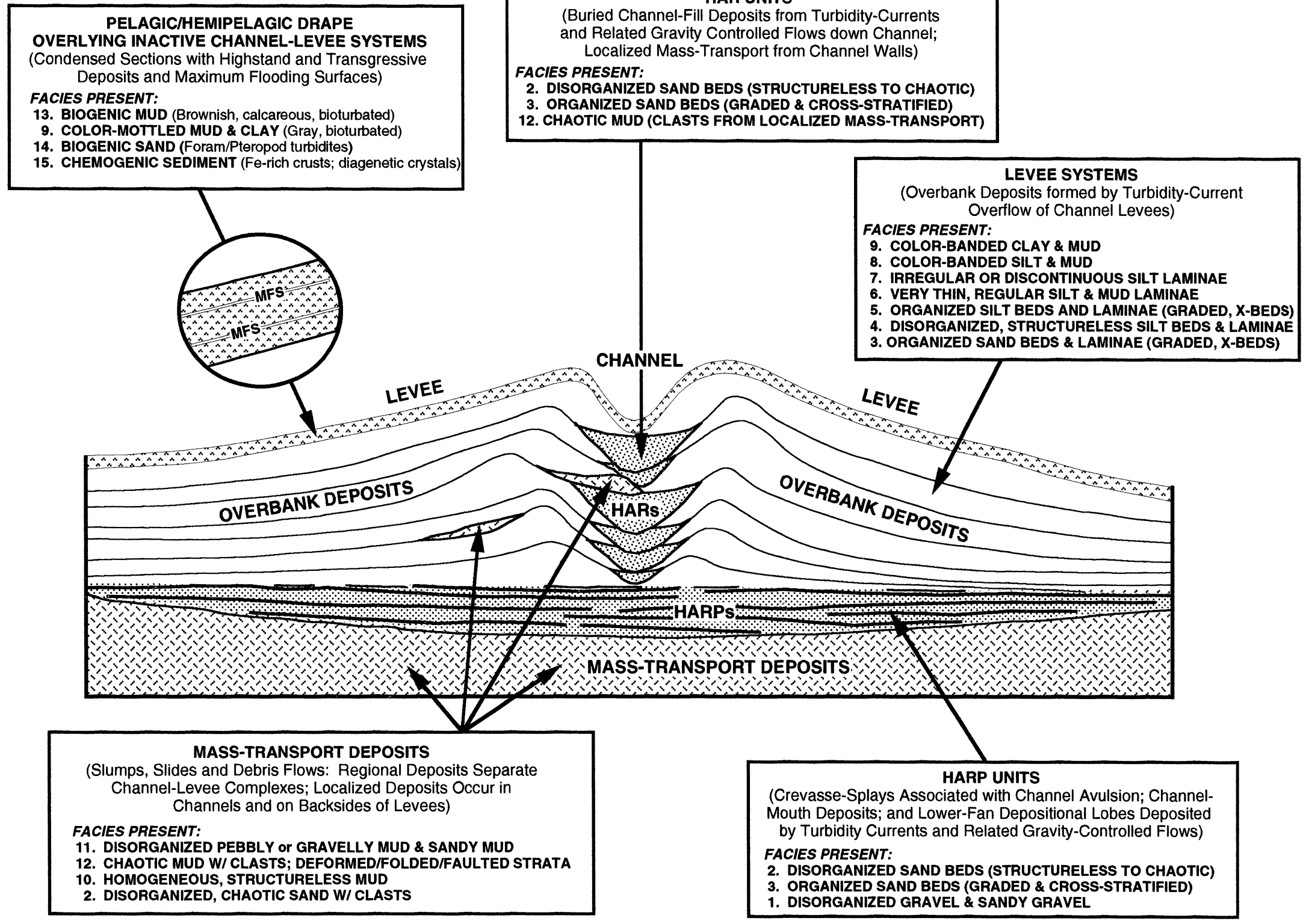

Figure 21. Schematic diagram showing the distribution of sedimentary facies within acoustic units (e.g., HAR units, HARP units) and turbidite elements (e.g., channel, levee/overbank, MTDs) of the Amazon Fan. The diagram shows a typical channel-levee system, which is the elemental stratigraphic unit of the fan, and an underlying regional-scale MTD. This stratigraphic relationship is typical of the upper and middle fan (Manley and Flood, 1988; Damuth et al., 1988; Flood et al., 1991; Flood, Piper, Klaus, et al., 1995). Lower fan deposits lack large channel-levee systems and,

\section{Previous Chapter}

Table of Contents

\section{Next Chapter}

